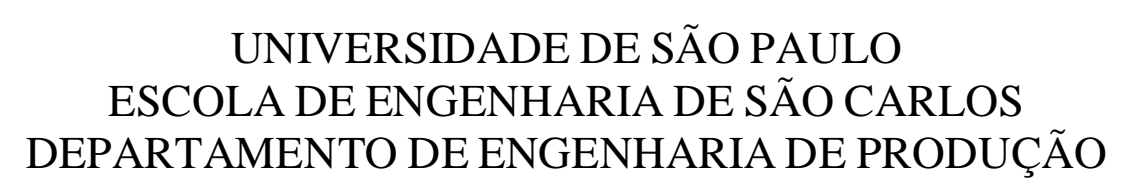

Pedro HenRIQue de Sousa Leão Araujo

\title{
ELABORAÇÃO DE RANKINGS POR MEIO DO USO DE TÉCNICAS ESTRUTURADAS: UMA APLICAÇÃO NO SETOR DE SEGUROS PRIVADOS
}

SÃO CARLOS 

Pedro HenRiQue de Sous a Leão Araujo

\section{ELABORAÇÃO DE RANKINGS POR MEIO DO USO DE TÉCNICAS ESTRUTURADAS: UMA APLICAÇÃO NO SETOR DE SEGUROS PRIVADOS}

Dissertação apresentada ao Departamento de Engenharia de Produção da Escola de Engenharia de São Carlos, Universidade de São Paulo, como requisito à obtenção do título de Mestre em Engenharia de Produção.

Área de Concentração: Finanças Corporativas Orientador: Prof. Dr. Marcelo Seido Nagano 
AUTORIZO A REPRODUÇÃO E DIVULGAÇÃO TOTAL OU PARCIAL DESTE TRABALHO, POR QUALQUER MEIO CONVENCIONAL OU ELETRÔNICO, PARA FINS DE ESTUDO E PESQUISA, DESDE QUE CITADA A FONTE.

Ficha catalográfica preparada pela Seção de Tratamento da Informação do Serviço de Biblioteca - EESC/USP

Araujo, Pedro Henrique de Sousa Leão
Elaboração de rankings por meio do uso de técnicas
estruturadas: uma aplicação no setor de seguros
privados / Pedro Henrique de Sousa Leão Araujo;
orientador Marco Marcelo Seido Nagano. -- São Carlos,
2008.
Dissertação (Mestrado-Programa de Pós-Graduação e Área
de Concentração em Engenharia de Produça) -- Escola de
Engenharia de São Carlos da Universidade de São Paulo,
2008.
1. Seguro Privado. 2. Rankings. 3. Redes neurais
Irtificiais. 4. Análise por envoltória de dados.
Título.


Candidato: Engenheiro PEDRO HENRIQUE DE SOUZA LEÃO ARAÚJO

Dissertação defendida e julgada em 26/11/2008 perante a Comissão Julgadora:

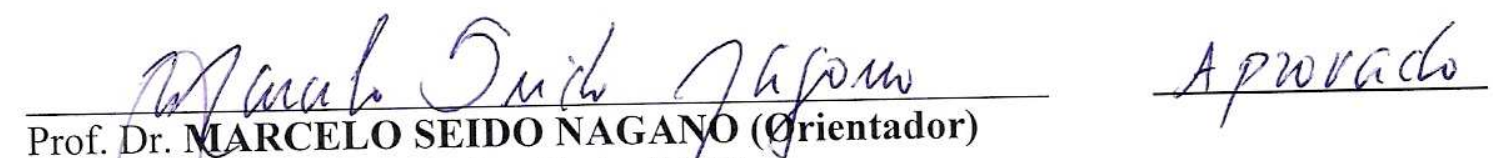
(Escola de Engenharia de São Carlos/USP)

Hasumento Prof ${ }^{a}$. Associada DAISY APARECIDA DO NASCIMENTO REBELATTO (Escola de Engenharia de São Carlos/USP)

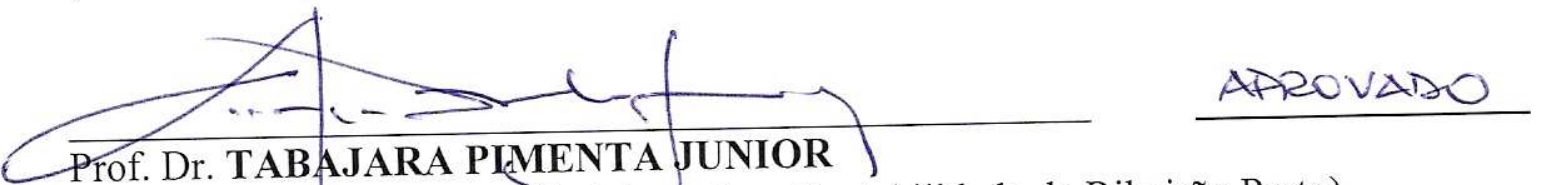

(Faculdade de Economia, Administração e Contabilidade de Ribeirão Preto)

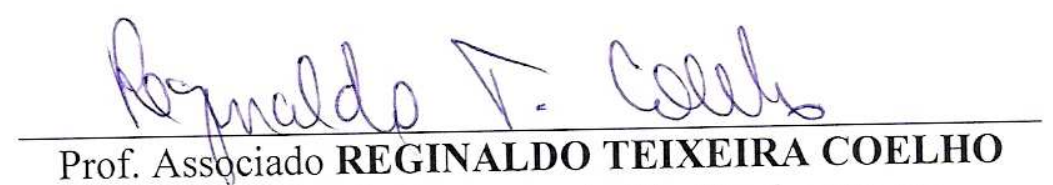

Coordenador do Programa de Pós-Graduação em

Engenharia de Produção

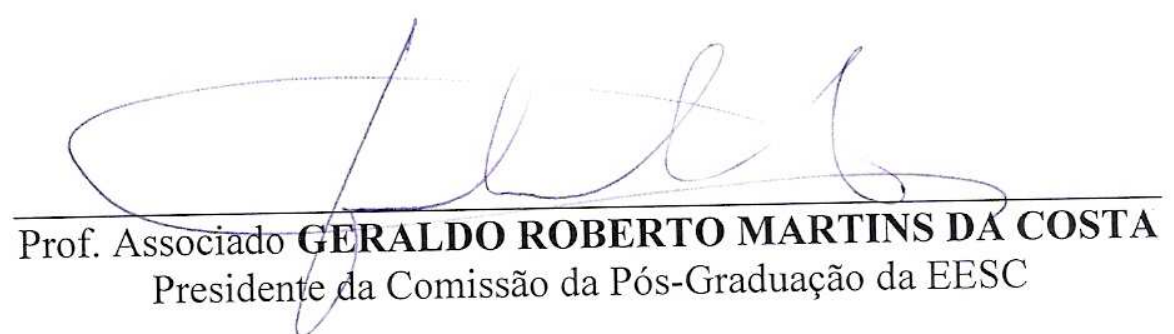




\section{DEDICATÓRIA}

À minha família e à minha companheira Mariana. Dedicar este trabalho à vocês é uma forma de retribuir todo o carinho, a compreensão e suporte que vocês me deram ao longo desta jornada. Obrigado. 


\section{AGRADECIMENTOS}

Agradeço a todos aqueles que, de alguma forma, contribuíram para conclusão deste trabalho. Todo o corpo docente do Departamento de Pós-Graduação em Engenharia de Produção, José Luis Chiaretto e sua equipe, e aos companheiros e companheiras do laboratório de Administração e Economia.

No entanto, é de merecido destaque os enfáticos agradecimentos:

Aos meus pais Pádua e Wanda, que por meio de grande sabedoria da qual dispõem, sempre acreditaram em mim e me mostraram o caminho para uma vida de lutas e realizações.

Ao meu irmão Caio, que me ensina como ser mais humilde e conhecedor de mim mesmo.

A minha namorada Mariana, que me apóia em todos os desafios que surgem e me dá força para continuar, sempre.

Ao meu orientador, Marcelo Seido Nagano, que por meio de muito esforço e compreensão, auxiliou-me com bastante proximidade na elaboração desta dissertação.

Aos amigos Vinícius Amorim Sobreiro, Débora Valente, Mariana Rodrigues de Almeida e Anderson Rodrigo dos Santos, que me ajudaram em todos os momentos de dificuldades. Vocês foram peças-chave em minha jornada em São Carlos.

Ao meu tutor Mário Morhy, que me cedeu incentivo e flexibilidade para a conclusão desta missão.

Aos meus amigos que sempre acreditaram em mim e me incentivaram a encarar este desafio.

Reconhecer e retribuir os esforços daqueles que me estendem a mão é uma de minhas maiores qualidades. Garanto que nada foi em vão, amigos. Sigamos juntos. 


\section{RESUMO}

ARAUJO, P.H.S.L. Elaboração de rankings por meio do uso de técnicas estruturadas: uma aplicação no setor de seguros privados. 2008. Dissertação (Mestrado em Engenharia de Produção) - Escola de Engenharia de São Carlos, Universidade de São Paulo, São Carlos, 2008.

Resumo. A demanda por metodologias para classificação de empresas que possuam características em comum e que componham um mesmo setor de atividade tem instigado pesquisadores a avaliar alternativas que sejam fidedignas à representação da realidade, e que façam uso reduzido de quesitos voltados à subjetividade de julgamento. Por isso, adotou-se como objetivo desta pesquisa a elaboração de rankings utilizando as técnicas de Análise por Envoltória de Dados e Redes Neurais Artificiais, com aplicação no setor de seguros privados, setor este de forte influência na economia nacional. Como dados para a aplicação das duas técnicas propostas, foram considerados alguns indicadores, via de regra adotados pelo setor, para avaliar o desempenho das empresas no cumprimento de suas atividades. Como resultado obtido, foi verificado que a ponderação direta de acordo com a importância de cada indicador não representa a única forma de apresentar uma ordenação justa das empresas consideradas com base em seus desempenhos. Por meio das técnicas utilizadas, foi observado que empresas que mantiveram um resultado satisfatório na maioria das variáveis consideradas obtiveram os melhores posicionamentos nos rankings. A rede neural, mesmo requerendo um maior tempo de processamento e oferecendo uma complexidade de aplicação maior que a técnica DEA, apresentou resultados mais consistentes.

Palavras-chave: Rankings, Redes Neurais Artificiais, Análise por Envoltória de Dados, Seguros Privados. 


\section{ABSTRACT}

Abstract. The demand for methodologies and procedures to classify companies that have some characteristics in common and that are part of the same activity sector has instigated researchers to evaluate alternatives that represent the real situation according to their performance as business units, by making use of reduced amount of subjectivity in the performance judgment. Therefore, this research has as its main goal the objective to set up some rankings using the techniques of Analysis and Data Envelopment by Artificial Neural Networks, by making applying these techniques in the insurance sector, a activity with great influence in national economy. As data for the implementation of both techniques proposed, some indicators well known by specialists were considered to evaluate the performance of companies in their activities. As a result, it was found that the direct weighting used to enforce the importance of each indicator is not the only way to make a fair ranking of the insurance companies. About the techniques used, it was observed that companies that have maintained a satisfactory performance in most of the variables considered occupied best positions in the rankings. The neural network, even though requiring a longer processing time, and offering a greater complexity of application than DEA technique, showed some more consistent results.

Key words: Rankings, Neural Net Works, Data Envoltory Analysis, Insurance. 


\section{LISTA DE ILUSTRAÇÕES}

Figura 1 - Market share do setor de seguros no mundo.............................................. 21

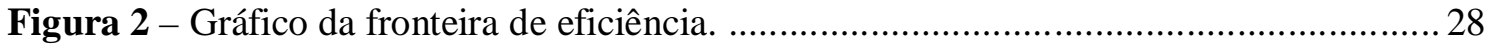

Figura 3 - Modelo CCR de Orientação ao insumo ou ao produto ...................................... 29

Figura 4 - Fronteira Clássica e Fronteira Invertida ...................................................... 35

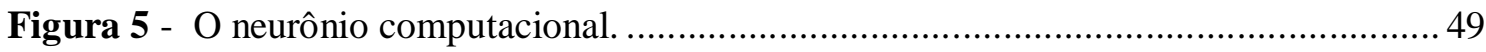

Figura 6 - Rede neural multicamadas: representação genérica...................................... 49

Figura 7 - Representação de um neurônio artificial......................................................... 52

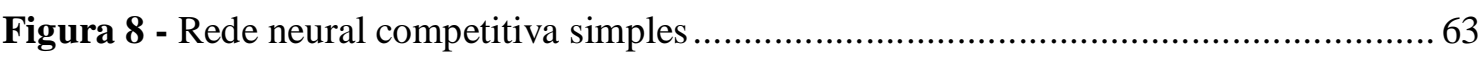

Figura 9 - Atualização dos pesos em uma rede neural competitiva ..................................... 64

Figura 10 - Rede SOM de tamanho 6x5, e dimensionalidade de entrada $\mathrm{p}=3$..................... 64

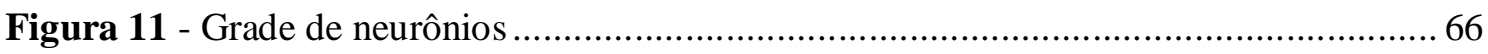

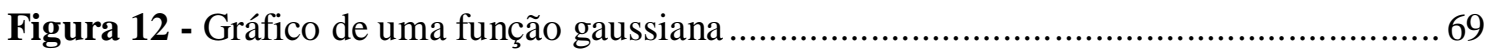

Figura 13 - Modelos DEA considerados na análise ..................................................... 77

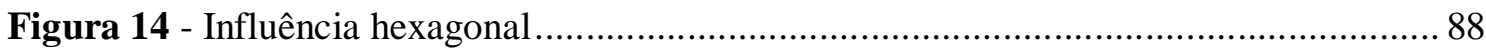

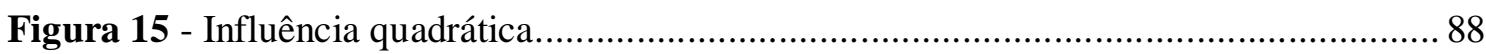

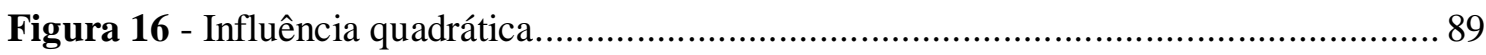

Figura 17 - Número de épocas versus Tempo de Convergência ...................................... 92

Figura 18 - Número de iterações versus Tempo de Convergência ..................................... 92

Figura 19 - Recomendações para Safra Vida e Previdência............................................ 104

Figura 20 - Recomendações para Safra (Fronteira Clássica).......................................... 104

Figura 21 - Características do neurônio 3, máximo, mínimo e mediana das séries............. 113

Figura 22 - Características do neurônio 100, máximo, mínimo e mediana das séries ......... 114

Figura 23 - Características do neurônio 80, máximo, mínimo e mediana das séries ........... 114

Figura 24 - Características do neurônio 1, máximo, mínimo e mediana das séries............. 115

Figura 25 - Características do neurônio 1, máximo, mínimo e mediana das séries............. 115

Figura 26 - Distribuição das empresas no espaço ....................................................... 116

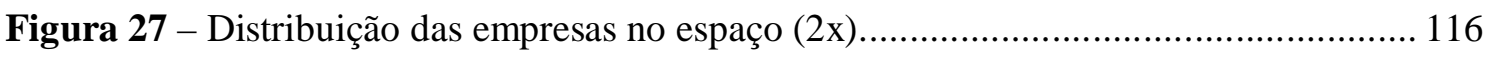

Figura 28 - Empresas com características distintas.................................................. 117 


\section{LISTA DE QUADROS E TABELAS}

Tabela 1 - Participação do mercado de seguros no PIB brasileiro ........................................ 19

Tabela 2 - Representação da área de finanças nas pesquisas de sistemas inteligentes ......... 47

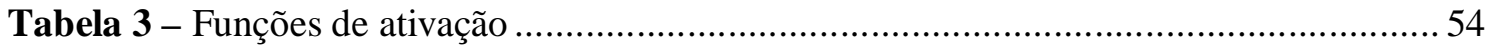

Tabela 4 - Eficiência média dos modelos ...................................................................... 79

Tabela 5 - Quantidade de DMU's eficientes dos modelos .............................................. 79

Tabela 6 - Coeficiente de correlação DEA versus Base de Dados sem ponderação.............. 80

Tabela 7 - Coeficiente de correlação DEA versus Base de Dados com ponderação. ............ 80

Tabela 8 - Posições iguais DEA versus Base de Dados .................................................. 81

Tabela 9 - Posições semelhantes DEA versus Base de Dados sem ponderação .................... 81

Tabela 10 - Modelos BCC orientado para a maximização dos outputs para Stepwise .......... 85

Tabela 11 - Correlação entre simulações da Rede Neural .................................................91

Tabela 12 - Comparação entre variáveis e pesos dos indicadores ..................................... 94

Tabela 13 - Ranking ordenado apenas por Prêmios Ganhos ............................................... 95

Tabela 14 - Ranking obtido com a aplicação de DEA.................................................... 99

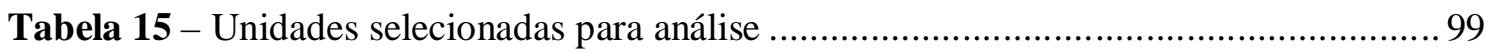

Tabela 16 - Características das DMU's escolhidas para análise .................................... 100

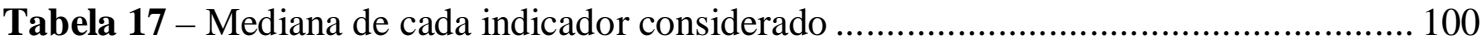

Tabela 18 - Comparação as características com as medianas das distribuições .................. 101

Tabela 19 - Associação entre empresas e neurônios ...................................................... 106

Tabela 20 - Distâncias dos neur6onios em relação ao neurônio ideal.................................. 108

Tabela 21 - Ranking obtido com a Rede Neural Artificial ............................................ 109

Tabela 22 - Processo de desempate entre empresas de uma mesma classe....................... 110

Tabela 23 - Ranking obtido com RNA após desempate............................................... 112

Quadro 1 - Exemplos de pesquisas voltadas para previsão.............................................49

Quadro 2 - Combinação de variáveis para o ajuste do modelo..........................................84 


\section{ÍNDICE}

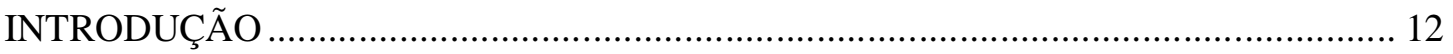

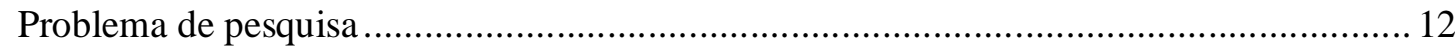

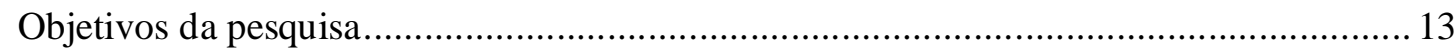

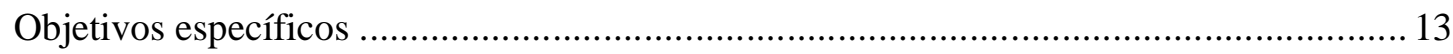

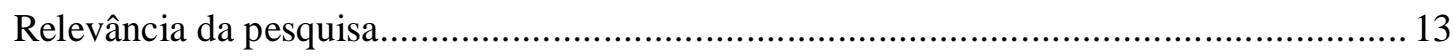

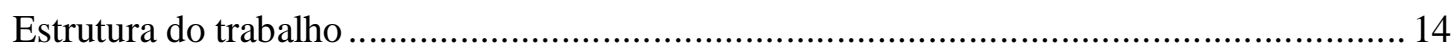

CAPÍTULO 1 - O SETOR DE SEGUROS PRIVADOS............................................. 16

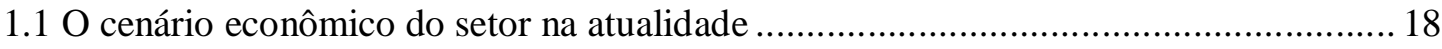

1.2 Problemas e Dificuldades enfrentadas pelo Setor de Seguros ...................................2 21

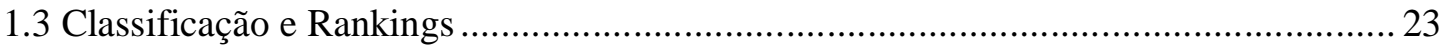

CAPÍTULO 2 - ANÁLISE POR ENVOLTÓRIA DE DADOS.......................................... 26

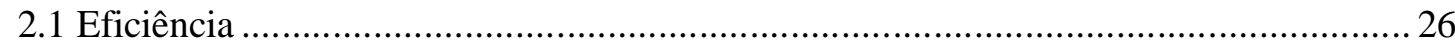

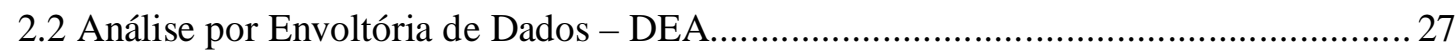

2.2.1 Cálculo da fronteira invertida e índice combinado........................................... 33

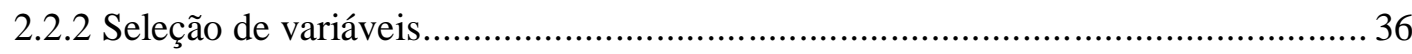

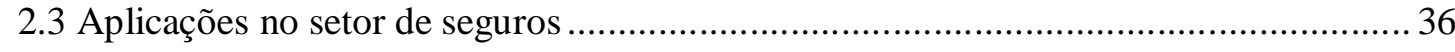

CAPÍTULO 3 - REDES NEURAIS ARTIFICIAIS ................................................... 39

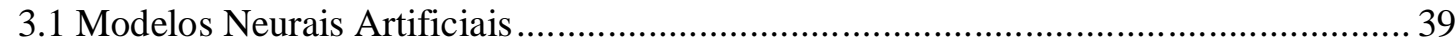

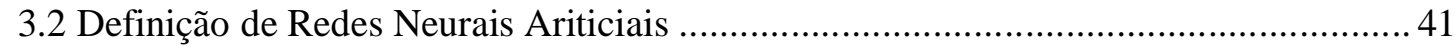

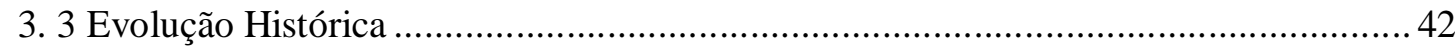

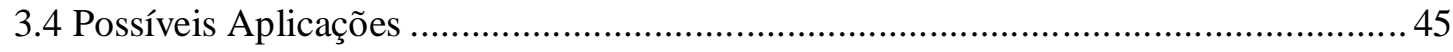

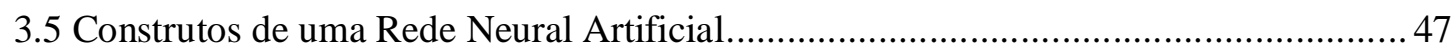

3.5.1 Categorias de Redes Neurais Artificiais ..................................................... 47

3.5.2 Analogia entre o neurônio computacional e o neurônio biológico ........................ 48

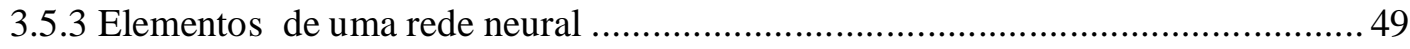

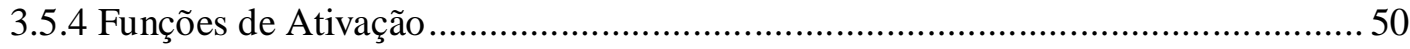

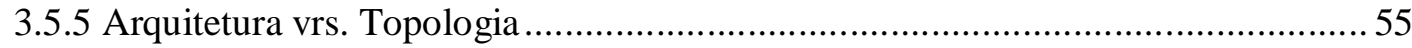

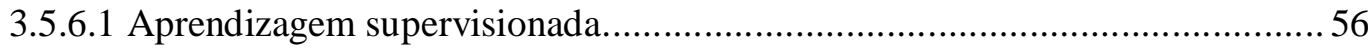

3.5.6.2 Aprendizagem auto-organizável (não-supervisionada) ................................57

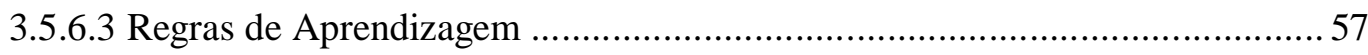

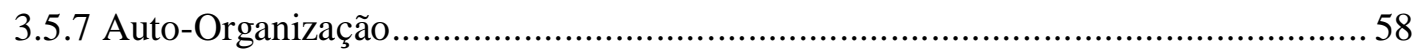




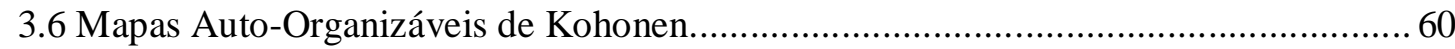

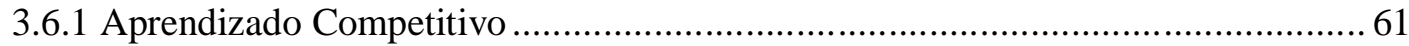

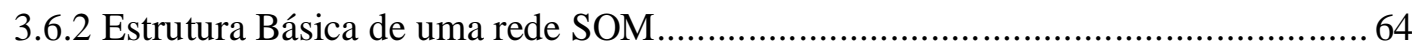

CAPÍTULO 4 - MÉTODO DE PESQUISA E PLANEJAMENTO DO EXPERIMENTO 71

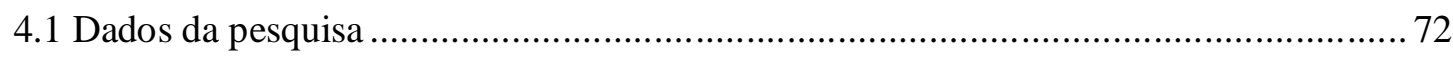

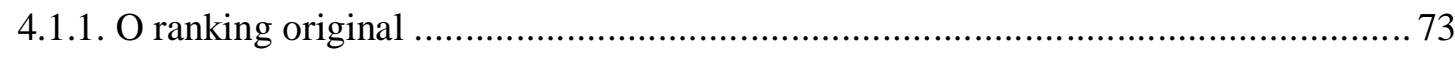

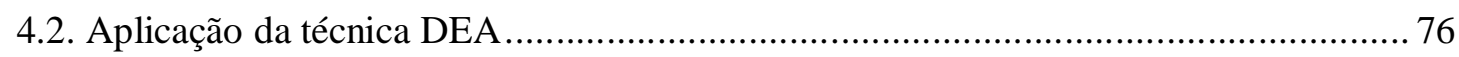

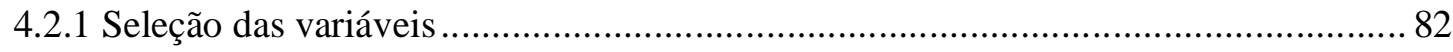

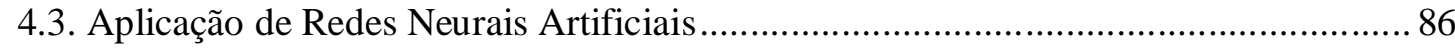

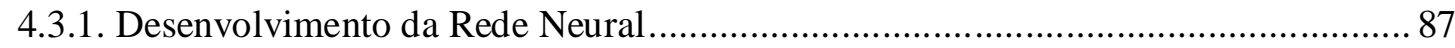

CAPÍTULO 5 - ANÁLISE DOS RESULTADOS OBTIDOS ….................................... 93

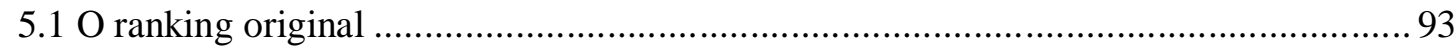

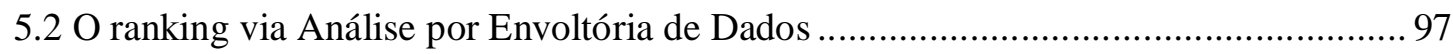

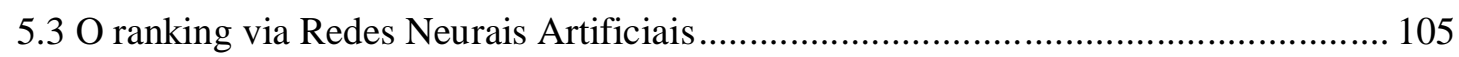

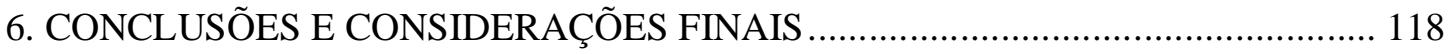

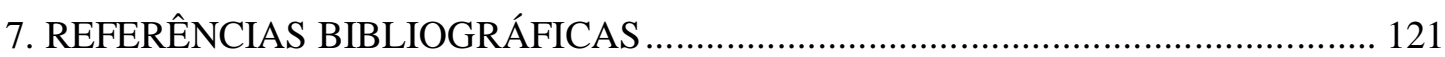




\section{INTRODUÇÃO}

O processo de tomada de decisões está presente na rotina de pessoas e corporações. Escolher dentre as diversas opções disponíveis é de pertinente complexidade, e está correlacionado com o sucesso ou fracasso daqueles que têm o poder da decisão - agentes decisores. No mundo globalizado e altamente concorrencial, as corporações quotidianamente se deparam com impasses que envolvem decisões inerentes à consequiências de caráter econômico-financeiro, operacional e humano, muitas vezes inesperadas e surpreendentes.

Os consumidores demandam por suporte à decisões sobre quais produtos adquirir e à quais empresas estes devem se tornar fiéis. Os investidores necessitam de informações sobre o desempenho das empresas, com o objetivo de selecionar as unidades merecedoras de seus aportes de capital. Já os gestores necessitam de informações que os tornem capazes de realizar um benchmarking e assim rever suas operações. Por isso, ferramentas que venham a auxiliar os processos de tomada de decisão são importantes diante da análise de qualquer cadeia de valor de bens de consumo ou serviços, em âmbito de stakeholders e stockholders.

O incremento da eficiência do processo de tomada de decisões consiste em um complexo processo de melhoria, de interesse comum entre os setores privado e público. Em um ambiente hostil por conta do processo de globalização, a competitividade das empresas está diretamente relacionada à sua capacidade de reduzir custos, sem perder desempenho e qualidade, já que os demais recursos, em princípio, estão disponibilizados para todos nas mesmas condições. E a capacidade de redução de custos, obtendo melhor retorno sobre o investimento, por sua vez, decorre, em grande escala, da qualidade das decisões tomadas pelas corporações.

Assim, esta pesquisa busca reunir aspectos mercadológicos, informações técnicas e um método descritivo exploratório com o intuito de contribuir para a literatura pertinente ao assunto e para o ambiente corporativo.

\section{Problema de pesquisa}

A pesquisa se propõe a elaborar uma classificação mediante a utilização de técnicas e metodologias fundamentadas em métodos quantitativos, com o objetivo de reduzir características indutivas à subjetividade em rankings voltados para o setor de seguros 
privados. A questão a ser respondida por este trabalho é: como elaborar rankings e classificar empresas de um mesmo setor, considerando suas características individuais e indicadores de desempenho, sem se beneficiar de um julgamento pré-determinado por parte dos responsáveis pelo estudo classificatório?

Objetivos da pesquisa

A pesquisa tem como objetivo geral o intuito de elaborar um ranking das empresas componentes do setor de seguros privados, mediante as técnicas de redes neurais e análise por envoltória de dados, para assim reduzir um possível caráter subjetivo de julgamento.

Objetivos específicos

- Revisar a literatura nacional e internacional pertinente às técnicas utilizadas e ao setor sob estudo;

- Caracterizar o setor de seguros privados nacional;

- Identificar os construtos que compõem as técnicas utilizadas - redes neurais e DEA, para a conseguinte estruturação dos modelos;

- Explorar e discorrer sobre os procedimentos necessários para a construção dos rankings propostos;

- Identificar quais as possíveis alternativas que não foram consideradas por esta pesquisa para solucionar o problema de pesquisa;

- Identificar uma possível demanda por este tipo de pesquisa, mediante a busca de credibilidade para os rankings publicados por revistas e periódicos.

\section{Relevância da pesquisa}

As empresas constituintes do setor de seguros compõem, juntamente com bancos, empresas prestadoras de serviços de previdência privada, entre outras, o denominado setor financeiro da economia nacional. Por isso, mediante o desenvolvimento do setor financeiro, torna-se capaz de estimular de uma forma direta a economia de uma nação (LEVINE et al., 2000). 
O setor de seguros privados contribui para estimular o crescimento da economia de uma nação, na medida em que é parte integrante do seu setor financeiro (LEVINE e ZERVOS, 1998; Levine, 1999; LEVINE et al., 2000; KING e LEVINE, 1993a, 1993b; BECK et al., 2000). Exemplos de como o mercado de seguros pode influir na economia são mencionados nos trabalhos de Outreville (1990) e Ward e Zurbruegg (2002). Esses autores postulam que a indústria do seguro é capaz de, por intermédio do gerenciamento de riscos, de intermediações financeiras e da geração de empregos, gerar benefícios para toda sua cadeia produtiva e também para o crescimento da economia de um país.

Tal fato justifica a relevância de toda e qualquer tentativa que, portanto, tenha a intenção de contribuir para a evolução do setor econômico e das pesquisas no campo das finanças. Uma vez atingidos os objetivos que esta pesquisa propõe, esta irá contribuir para a obtenção de classificações e julgamentos de desempenhos mais justos e transparentes.

Assim, este trabalho utiliza o fato de as empresas de seguros contribuírem consideravelmente para o setor financeiro mediante a alocação de seus capitais e reservas em investimentos como títulos, mercado de ações, mercado imobiliário, entre outros, para justificar a relevância de se utilizar este setor como aplicação para as técnicas propostas.

\section{Estrutura do trabalho}

A seguir, encontra-se o capítulo um, que desenha o setor de seguros privados, passando por sua evolução histórica até chegar a seu cenário atual. Delineia-se seu papel para a economia nacional, sua participação para o crescimento do Produto Interno Bruto - PIB, expõe as suas operações de alocação de reservas e corrobora alguns dos principais desafios para o setor.

O capítulo dois trata da técnica denominada análise por envoltória de dados, e traz uma breve noção do conceito de eficiência, assim como a origem da técnica DEA e seus principais modelos. Dando continuidade, um levantamento sobre as suas mais pertinentes aplicações gerais, no setor de seguros e no campo das finanças.

O capítulo três explora o tema Redes Neurais, apresentando uma visão geral da técnica, seus construtos e suas principais aplicações. Não obstante, este capítulo adentra a rede neural a ser utilizada - Mapas Auto-organizáveis de Kohonen, explanando sua metodologia de implantação e demais particularidades. 
O capítulo quatro discorre sobre o método utilizado para obter os resultados que se objetiva. Foi realizada uma avaliação do ranking da revista Conjuntura Econômica, explorando seus pontos fortes e fracos. Em seguida, no mesmo capítulo, foi discorrido sobre o método utilizado para aplicação das duas técnicas propostas - Análise por Envoltória de Dados e Redes Neurais Artificiais.

O capítulo cinco apresenta os resultados obtidos com as aplicações, e o capítulo seis finaliza a pesquisa apresentando as conclusões e propostas para pesquisas futuras. 


\section{CAPÍTULO 1 - O SETOR DE SEGUROS PRIVADOS}

Nos novos tempos, definidos por muitos autores como Era da Pós-Modernidade, emerge a necessidade de se desenvolver toda e qualquer ciência que possa vir a contribuir para a melhoria das condições de vida das sociedades contemporâneas. Neste contexto, a ciência estatística e o campo das ciências atuariais vêm demonstrando consideráveis avanços. Com a evolução dos cálculos de incidência de certos eventos aleatórios, antes imprevisíveis, tornou-se possível determinar, de uma maneira tangível, fatos que venham a interferir em processos decisórios de maneira colaborativa, degenerativa, ou ainda, de forma neutra.

Especialmente para o setor de seguros, os avanços neste campo do conhecimento possibilitam, atualmente, prever, com maior grau de certeza, aspectos relevantes que podem levar ao sucesso ou fracasso das opções estratégicas selecionadas. Diante dos avanços tecnológicos, dos elevados índices populacionais atualmente verificados no mundo, da globalização da economia, do desequilíbrio do ecossistema mundial e da busca obstinada pela maximização de receitas, as empresas que integram o setor de seguros enfrentam o desafio de encontrar soluções que consigam agregar valor aos produtos ofertados ao mercado e, ao mesmo tempo, tornarem-se competitivas enquanto instituições com fins lucrativos.

Segundo Standerski (1979), a atividade exercida pelo setor de seguros tem por finalidade proteger bens, responsabilidades, créditos, obrigações, direitos, garantias e pessoas, mediante o recebimento de prêmios do segurado como contrapartida para a obrigação contratual de indenizá-lo, em caso de ocorrência de eventos aleatórios e fatalísticos que venham a comprometer o objeto do seguro.

De uma maneira geral, a atividade seguradora surgiu diante da necessidade de proteção de possíveis prejuízos gerados pelas mais diversas causas. De acordo com Allen (1949), a prática de um dos fundamentos da atividade seguradora, o mutualismo, é tão antiga

quanto a civilização. Atividades de seguro firmadas entre condutores de caravanas da Mesopotâmia, 2.250 anos antes da era Cristã, são exemplos que demonstram a remota origem de tal atividade. O foenus nauticus - empréstimo marítimo a risco - vem sendo praticado 
desde a Grécia Antiga, assim como o Lex Rhodia do Império Romano - seguro marítimo para cargas lançadas ao mar em situação de perigo (MAYERSON, 1962).

No Brasil, a atividade de seguros foi introduzida durante as primeiras décadas após o descobrimento. O ramo de seguradoras, criado por jesuítas da era colonial, faz parte das mais antigas atividades econômicas regulamentadas no país, e teve o Padre José de Anchieta como grande incentivador do mutualismo ligado à assistência - seguro primitivo. Segundo os relatos da Escola Nacional de Seguros - FUNENSEG, a regulamentação mais remota da atividade seguradora data de 1791, quando foram promulgadas as "Regulações da Casa de Seguros de Lisboa", mantidas em vigor até a proclamação da independência, em 1822. Devido à abertura dos portos brasileiros em 1808, iniciaram-se as atividades da primeira seguradora a operar oficialmente no Brasil exploração de seguros marítimos, por parte da Companhia de Seguros Boa Fé sediada na Bahia.

Atualmente, o setor nacional de seguros é composto por mais de uma centena de empresas, entre instituições nacionais e grupos estrangeiros, tendo como produtos principais os seguros automotivos, os seguros de vida e os seguros de saúde. As maiores empresas de seguros privados e previdência do setor possuem capital aberto para o mercado de valores mobiliários e negociam suas ações na Bolsa de Valores de São Paulo-BOVESPA:

- Itaú Seguros - Itauseg;

- Companhia Participações Aliança da Bahia - Par Al Bahia;

- Porto Seguro;

- Companhia de Seguros Aliança da Bahia - Seg. Al Bahia;

- Companhia de Seguros Minas Brasil - Seg. Min. Brás;

- Sul América.

É importante registrar que o setor vem tendo uma expressiva evolução, apesar do atual cenário de transformações rápidas, caracterizado pela imprevisibilidade. Uma das razões para isso pode decorrer do fato de que as práticas de seguros não são baseadas em verdades supremas e, por isso, são caracterizadas como atividades de alta versatilidade. Glenn (2003) afirma que antes da determinação de todos os termos da apólice de um seguro, de se utilizar alguma metodologia atuária e antes da compilação de todos os dados para a geração de um produto de seguros, entre outras etapas, devem-se adotar alguns pressupostos gerais sobre a relação entre a atividade seguradora e a natureza do mundo em que está inserida. Em outras palavras, é preciso estar, permanentemente, avaliando o ambiente externo numa perspectiva crítica, para que as decisões sejam respaldadas em tendências futuras que possas minimizar os 
riscos inerentes à atividade.

\subsection{O cenário econômico do setor na atualidade}

Até o final da década de 80, o setor de seguros no país se desenvolvia de forma lenta e ineficiente. Mesmo sendo um período de alto crescimento de renda para o Brasil, o quociente entre a soma dos prêmios ganhos (valores pagos pelo segurado à empresa seguradora para que esta cumpra sua parte do acordo em caso de necessidade de indenização) e o Produto Interno Bruto do Brasil manteve-se por volta de 1\%, indicador predominante ao longo da década.

Em 1994, a partir do processo de estabilização da moeda vigente na economia nacional, da privatização de empresas públicas e da abertura da economia ao exterior, o setor de seguros passou a se desenvolver com maior intensidade. Segundo Borges (2007), entre 1993 e 2000, o mercado segurador brasileiro incrementou o quociente PRÊMIOS/PIB de $1,4 \%$ para $2,1 \%$. No ano 1995 , o mercado de seguros brasileiro teve um faturamento de $\mathrm{R} \$$ 16,32 bilhões, montante que se elevou para cerca de R \$ 65,5 bilhões, em 2005.

Via de regra, o ganho das seguradoras provém de um complexo sistema de equações atuárias que envolve desde a previsão da incidência dos riscos assumidos de ocorrerem, passando pela taxas de juros aplicadas sobre o investimento das reservas e até a probabilidade de ocorrência de eventos aleatórios como ciclones e furacões.

Entretanto, segundo Bueno (2005), os principais lucros das empresas de seguro advêm da aplicação do dinheiro daqueles que compram seguros - os segurados - no mercado financeiro. Pelo período que o dinheiro da compra de seguros não é utilizado para pagar a perda de um bem, a empresa seguradora obtém lucros com o investimento de tais reservas em fundos de investimentos, ações ou ainda em outras opões disponíveis no mercado de finanças. Desmond (2006) afirma que empresas direcionadas especificamente para seguros de vida tendem a alocar suas reservas no mercado de ações e em títulos do governo, além de agências de crédito voltadas para a agricultura.

Em 2003, com o início do governo Lula e com as promessas de quedas na taxa de juros básica SELIC, as seguradoras tiveram que ajustar-se à nova realidade. A teoria de finanças assegura que quanto mais altas forem as taxas de juros, maior o faturamento com aplicações das denominadas reservas técnicas. Consequentemente, diante da perspectiva de desaquecimento da economia e da queda da taxa SELIC, as empresas seguradoras tiveram que aproveitar o período de taxas de juros elevadas para ainda faturarem com a alocação de suas reservas no mercado financeiro e, ao mesmo tempo, passaram a reduzir custos, otimizar 
processos de produção de serviços prestados e redefinir suas margens operacionais, para se manterem competitivas no novo cenário de juros decrescentes.

Apesar de a ciência atuária fornecer elementos importantes para a definição do valor dos produtos oferecidos pelas seguradoras, ainda persiste a dificuldade para o cálculo de sua demanda.

Em recentes pesquisas empíricas sobre o mercado de seguros, os autores Browne et al. (2000), Ward e Zurbruegg (2002), Beck e Webb (2003), e Esho et al. (2004) mostraram que o nível da demanda por serviços seguradores de uma economia pode ser influenciado por um número elevado de variáveis particulares como inflação, câmbio, estabilidade política, grau de corrupção nos diversos níveis políticos, variação do Índice de Desenvolvimento Humano IDH, e variação do Produto Interno Bruto - PIB.

De um modo geral, pode-se afirmar que o mercado de seguros no Brasil ainda é limitado. Em 2005, o total de prêmios do setor foi equivalente a 2,63\% do PIB, enquanto que nos Estados Unidos a participação deste setor no PIB se aproximou de 10\%. Mesmo considerando-se as especificidades de cada país, é fato que o mercado de seguros brasileiro ainda tem um grande potencial de crescimento. A Tabela 1 apresentada a seguir demonstra a evolução da participação do setor no Produto Interno Bruto nacional ao longo dos últimos 10 anos.

\begin{tabular}{c|c|c|c} 
Ano & $\begin{array}{c}\text { Prêmio (em R\$ } \\
\text { milhões) }\end{array}$ & Part. PIB (\%) & PIB (em R\$ Milhões) \\
\hline 1995 & 16.320 & 2,53 & 646.192 \\
\hline 1996 & 22.355 & 2,87 & 778.887 \\
\hline 1997 & 25.028 & 2,87 & 870.743 \\
\hline 1998 & 26.181 & 2,86 & 914.188 \\
\hline 1999 & 28.275 & 2,90 & 973.846 \\
\hline 2000 & 32.763 & 2,98 & 1.101 .255 \\
\hline 2001 & 37.656 & 3,14 & 1.346 .736 \\
\hline 2002 & 42.514 & 3,16 & 1.556 .182 \\
\hline 2003 & 51.161 & 3,29 & 1.766 .621 \\
\hline 2004 & 59.824 & 3,39 & 1.937 .598
\end{tabular}

Tabela 1 - Participação do mercado de seguros no PIB brasileiro

Fonte: Federação Nacional das Empresas de Seguros Privados e de Capitalização, 2007.

Até o ano de 2005, a atividade de resseguros era concentrada em sua totalidade no Instituto de Resseguros do Brasil - Brasil Resseguros (IRB-Re). O resseguro consiste na operação realizada por parte das seguradoras para transferir à empresa de resseguros o montante de responsabilidade excedente ao limite da sua capacidade econômica de arcar com o compromisso perante seus clientes. Unctad $(1982,1994)$ e Outreville $(2000)$ demonstraram, 
em seus respectivos trabalhos, o papel do resseguro no desenvolvimento do setor de seguros como todo.

No ano de 2006 foi decretada a quebra gradual do monopólio do IRB-Re. Segundo Borges (2007), esta medida foi tida como uma das melhores notícias que o mercado de seguros já teve nos últimos anos. A adoção dessa medida implicará o aumento do interesse por parte das seguradoras estrangeiras pelo mercado brasileiro e algumas seguradoras que não poderão mais contar com a ajuda irrestrita do IRB-Re terão que reavaliar seu comportamento no mercado.

No que se refere à participação dos produtos de seguro no mercado, no ano de 2006, segundo Borges (2007), em artigo publicado na revista Conjuntura Econômica, o produto voltado para seguros de automóvel obteve $26 \%$ dos prêmios totais arrecadados pelas seguradoras até fevereiro de 2007.

Cabe destacar que o mercado de seguros terminou o ano de 2006 com um volume de prêmios $17,8 \%$ maior que o registrado em 2005. Dentre os ramos que fazem parte do mercado, os produtos VGBL, Auto e o Seguro de Danos Pessoais Causados por Veículos Automotores de Vias Terrestres - DPVAT foram responsáveis por $75 \%$ do aumento dos prêmios ganhos. Já a margem operacional de seguros ficou em $-0,2 \%$, o que representa um substancial avanço em relação aos $-5,4 \%$ obtidos em 2005 . Esse fato impactou positivamente o resultado financeiro, que evoluiu de $16,3 \%$ para $20,6 \%$, uma evolução considerável.

Assim, com base nos dados explicitados anteriormente, pode-se afirmar que o ramo de seguros no Brasil apresenta gradativa evolução. A área de previdência privada aberta tem sido a principal responsável pelo crescimento do setor de seguros no Brasil. Produtos como Vida Gerador de Benefício Livre - VGBL e Plano Gerador de Benefício Livre - PGBL, que são do tipo contribuição definida, têm sido ofertados massivamente no mercado. Tais produtos oferecem a opção de, numa certa idade pré-definida, o comprador de tais benefícios optar por receber uma renda vitalícia. 
Sob uma perspectiva global, o Anuário de Estatísticas do Setor de Seguros publicado pela Organization for Economic Co-Operation and Development - OECD afirma que os Estados Unidos arrecadou, em 2004, $43 \%$ de todos os prêmios coletados pelo setor no mundo. Em seguida, Japão e Reino Unido com 10\%. A Figura 1 apresentada a abaixo demonstra a divisão de prêmios arrecadados por país, durante o ano de 2004.

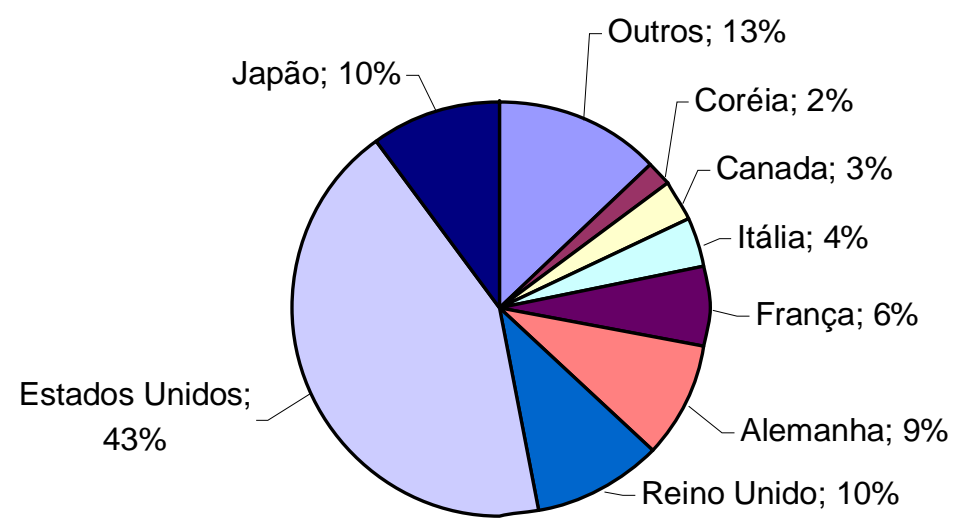

Figura 1 - Market share do setor de seguros no mundo.

Fonte: Adaptado do Anuário de Estatísticas do setor de Seguros, (2004).

Como pode ser observado pela análise dos dados constantes da Figura 1, Estados Unidos e Japão são os países do globo nos quais o setor de seguros apresenta maior participação, uma vez que, juntos, estes paises acumulam mais de cinqüenta por cento do total de prêmios ganhos pelo setor no mundo. Em seguida, encontram-se Reino Unido, Alemanha, França e Itália.

O setor de seguros também vem ganhando bastante representatividade na China. Diante do elevado índice populacional de 1,3 bilhões de habitantes e do precoce e elevado grau de industrialização, é compreensível que o ramo segurador esteja bem acondicionado. Segundo Desmong (2006), em 2004, três das quatro maiores seguradoras da China não foram capazes de atender à demanda por serviços de seguros de vida. Este indicador aponta que o setor possui significativa margem para crescimento, mesmo diante da acirrada concorrência.

\subsection{Problemas e Dificuldades enfrentadas pelo Setor de Seguros}

O setor de seguros, como qualquer outro setor de negócios, enfrenta inúmeras dificuldades para se estabelecer como forte contribuinte para o desenvolvimento econômico do país, bem como para obter níveis de resultados semelhantes a outros países também 
considerados em fase de desenvolvimento. Não há dúvida de que tanto a estabilidade da economia obtida ao longo dos últimos anos quanto à quebra do monopólio do resseguro, que se iniciou em 2007 e se estenderá, de forma gradual, pelos próximos três anos, foram benéficas para o setor. Entretanto, existem problemas intrínsecos ao ramo que pressionam as seguradoras a otimizarem seus processos e buscarem soluções para suas dificuldades.

Como já explicitado anteriormente, a economia enfrenta a situação da gradativa queda da taxa de juros básica SELIC. Quando se refere à aplicação das reservas no mercado financeiro, Bueno (2005) afirma que quanto mais altos forem os juros, maior será o faturamento com essas aplicações. Vista sob esta perspectiva, a queda da taxa básica representa, em parte, um fator prejudicial para as seguradoras, que atualmente atuam no mercado com margens apertadas devido à acirrada concorrência e carga tributária excessiva.

Outra dificuldade enfrentada pelas empresas de seguro em geral, especialmente em nações de situações geográficas desfavoráveis, são as catástrofes naturais que, nos últimos tempos, têm aumentado exponencialmente. Segundo Hoyt e McCullough (1999), a correlação entre a freqüência com a qual catástrofes ocorrem e seus devidos danos é um fator difícil de ser determinar. Carson (2002) cita que os valores subestimados dos produtos oferecidos pelas seguradoras, o baixo retorno dos investimentos das reservas técnicas no mercado financeiro, assim como catástrofes de causas naturais e humanas, combinadas, contribuíram para que o setor de seguros mundial fechasse o ano de 2001 como seu primeiro ano de toda a história com um resultado negativo.

Já o trabalho de Ostaszewski publicado em 2003 discorre sobre as instituições financeiras, afirmando que estas, como bancos regulares, bancos de investimento e companhias de seguro, estão inseridos em um ramo de negócio distinto. Não se incluem no ramo comercial propriamente dito, porém, ficam na função de dar suporte e condições para que este funcione de maneira apropriada. Assim, tais instituições encontram-se classificadas como setor de atividade que promove o suporte para ações de vários outros ramos, pois fornecem fundos e suprem a demanda por segurança em seus negócios.

Segundo Black e Skipper (2000), pode-se presumir que o setor de seguros está fortemente correlacionado com o ciclo de vida do ser humano de forma geral. Assim, cabe a atividade seguradora encontrar meios para estudar os eventos aleatórios passíveis de ocorrência, suas probabilidades e conseqüências. Tais necessidades incorrem na utilização por parte da atividade seguradora de técnicas e ferramentas voltadas para a matemática e estatística.

Desmond (2006) questiona a capacidade do corpo de funcionários alocados no setor 
para executarem suas tarefas com o nível de competência exigido pelo mercado. Isso se deve a fatores intrínsecos do setor, como a dificuldade se operar com complexos sistemas matemáticos e softwares bastante específicos. No que se refere a fatores extrínsecos, como acontece em qualquer ramo de negócios, as companhias seguradoras enfrentam dificuldades para adequarem seus produtos a um preço justo e absorvível pelo mercado consumidor, para incrementar eficiência operacional e para otimizar a qualidade dos serviços prestados.

O setor de seguros também sofre com os mais diversos tipos de inadimplência. Para ilustrar este problema, em 2004, a quantidade de segurados que tentaram burlar as normas para se beneficiar indevidamente do direito à indenização representou cerca de $25 \%$ das indenizações pagas, de acordo com Bueno (2005). Brockett et al.(1998) citam que um dos problemas principais da indústria de seguros é representado pela constante tentativa de se fraudar o sistema segurador. Já Kim e Kwon (2006) afirmam que todo e qualquer contrato de seguros requer um interesse segurável, e que sem este requisito pessoas e empresas sem ética nem moral podem vir a usar a atividade seguradora para burlar as leis e se beneficiar do que as empresas seguradoras podem lhes propiciar. Assim, esses inadimplentes em potenciais se apegam aos benefícios indiretos da atividade seguradora, e deixam de lado o propósito maior de uma apólice de seguros, que é garantir a proteção contra perdas futuras de bens ou ainda cobertura de vida.

\subsection{Classificação e Rankings}

Em um determinado mercado, a concentração de capital e aporte de operações sob o domínio de algumas poucas empresas gera uma situação desfavorável de oligopólio tendencioso. Tal cenário pode implicar prejuízos para os consumidores e também para as empresas menos elásticas que não estão inseridas no grupo denominado de líder.

Por isso, faz-se necessária a realização de estudos mercadológicos, com o objetivo de tornar mais evidente o que está por trás das demonstrações contábeis. Estudos como os de Godet e Roubelat (1996), que visam eleger as melhores empresas de um determinado setor, ou ainda como os que propõem cenários sob um caráter prospector dentro de um determinado segmento de mercado são essenciais para todos aqueles que compõem a cadeia de negócio dos produtos já existentes ou em fase de estudo.

Estes estudos servem como parâmetro para benchmarking, e, também, para que as empresas possam reavaliar suas estratégias e operações. Até os próprios clientes consumidores - se beneficiam de estudos como os descritos, pois as empresas bem colocadas 
ou classificadas passam a contar com uma imagem de elevada qualidade e credibilidade por parte de seus produtos e serviços. Ao ser reconhecida como líder de um segmento, a empresa se torna atrativa, tanto para clientes em potencial, como para investidores.

Daí a surge a importância de se elaborar classificações que sirvam de orientações em processos decisórios e que atuem como fonte de consulta em avaliações de desempenho as mais diferentes naturezas.

Segundo Tatikonda e Wemmerlov (1992), sistemas de classificação representam uma ferramenta capaz de ordenar componentes de um determinado conjunto ou amostra, com base em atributos pré-estabelecidos. Para classificar, independentemente da natureza dos dados, faz-se necessária a utilização de abordagens apropriadas, como algoritmos de otimização, modelagens multicritério, entre outros modelos estatísticos que viabilizem a utilização de um representativo número de variáveis simultaneamente.

Neste trabalho, a palavra ranking, que se traduz para a língua portuguesa como ordenação, será tratada por seu significado natural na língua inglesa, devido a sua praticidade e melhor participação por parte daqueles que irão, de alguma forma, utilizar as informações constantes dessa pesquisa.

A definição de ranking pode ser compreendida a partir de um conjunto de casos componentes de uma amostra que dispõem de certos atributos de natureza comum entre si, e uma ou mais propriedades de interesse combinadas a um atributo específico. Assim, ranking pode ser definido como uma ordenação desses casos, de acordo com suas relações individuais para com a propriedade de interesse que resulta no atributo em questão.

Segundo Caruana et al. (1995), uma maneira direta de se estabelecer um ranking seria fazer uso de um algoritmo de aprendizado que estabeleça um valor que sirva de parâmetro comparativo para que os casos venham ou não pertencer à classe de interesse. Cohen et al. (1999) também ressaltam que o valor determinado por esses tipos de algoritmos pode ser utilizado para ordenar os casos.

Via de regra, rankings são estabelecidos com base em indicadores das mais variadas naturezas, que são organizados por ordem de prioridade. Em um ranking que, por exemplo, procure classificar por ordem de desempenho operacional um grupo de corporações com características comuns entre si, a posição que uma empresa obter como colocação final será determinado pelo resultado da combinação entre os indicadores e as suas representatividades.

Sabe-se que, na economia moderna, indicadores passaram a ser muito utilizados como uma das principais ferramentas para se mensurar o desempenho de unidades de processamento, sejam elas empresas de mercado, organizações não-governamentais, governos 
ou outras instituições públicas que interagem, de alguma forma, com a economia de uma nação (PLOCEK, 1991; HORN, 1993), com o objetivo de se avaliar os caminhos e estratégias adotadas (MACRAE, 1985).

Existe um artigo, publicado anualmente desde 2001 pela Revista Conjuntura Econômica, que traz especificamente uma classificação de todas as empresas atuantes no setor de seguros privados. Esses estudos sempre consideram alguns indicadores operacionais e econômico-financeiros, como sinistralidade, rentabilidade do patrimônio líquido e prêmios ganhos - indicadores testes que serão explorados com mais afinco no capítulo referente ao método. Mas se faz importante ressaltar que, ano a ano, o ranking publicado apresenta variações em sua metodologia, seja com relação aos indicadores considerados, seja quanto à importância dividida entre as variáveis componentes do modelo (ponderação). Em 2007, Borges considerou indicadores diferentes do trabalho de Bueno (2006), por exemplo. Sabe-se que a economia possui caráter estritamente dinâmico, e que esta característica se estende a todos que com ela se correlacionam. Mas essa variação na metodologia deve ser fundamentada em sua essência, sempre que ocorrer.

Ao explorar o método da pesquisa, maiores informações sobre os indicadores considerados nas análises serão fornecidas. Na seção referente ao método também foi discutida questão da variação de metodologias apresentadas ao longo dos anos pelo trabalho de Borges (2007) e Bueno (2006). No entanto, antes de tal seção, são apresentadas as duas técnicas que este trabalho fez uso - Análise pro Envoltória de Dados e Redes Neurais Artificiais. 


\section{CAPÍTULO 2 - ANÁLISE POR ENVOLTÓRIA DE DADOS}

A análise por envoltória de dados, ou Data Envelopment Analisys - DEA é resultado de pesquisas voltadas soluções em modelagens de problemas de programação linear. Consiste em uma metodologia de análise de eficiência que compara o desempenho das unidades consideradas na análise, estabelecendo uma relação entre o uso de recursos exigidos em um determinado processo - inputs, e a quantidade de resultados obtidos do mesmo - outputs.

O ambiente no qual as companhias com fins lucrativos estão inseridas é caracterizado por um sistema bastante complexo, ao qual inferem variáveis de caráter econômico, financeiro, social e político, todas de amplitude globalizada. Portanto, trata-se de um ambiente difícil de ser definido mediante o uso de indicadores e resultados contábeis. Ainda assim, ao se tentar definir rankings e eleger as corporações de melhor desempenho, muitos estudos utilizam critérios de julgamento de caráter subjetivo.

Com o objetivo de eliminar a subjetividade nesses tipos de pesquisas, estudiosos vêm desenvolvendo ferramentas matemáticas que, mediante o uso de indicadores quantitativos, têm o papel de identificar as unidades mais eficientes. Esse tipo de classificação traz benefícios para todos os agentes atuantes em processos de tomadas de decisões que envolvem quaisquer corporações sob estudo - acionistas, investidores, órgãos recolhedores de tributos e impostos, e os consumidores diretos.

\subsection{Eficiência}

De uma forma geral, a literatura define eficiência como a habilidade de uma unidade produtiva - de bens de consumo ou serviços, de maximizar os resultados de suas operações outputs, considerando um determinado montante de inputs, ou ainda o inverso, de minimizar os inputs, mantendo-se fixo o montante de outputs resultados do processo (VARIAN, 1992).

Assim, pode-se definir eficiência pela simples Expressão 1, a seguir:

Eficiência $=$ output $/$ input

O problema sobre eficiência que recai sobre as empresas em estudo consiste no fato de 
que toda e qualquer empresa deve sempre avaliar seu desempenho próprio, e não obstante, compará-lo com o desempenho de suas concorrentes. Com isso, há um incremento na qualidade dos serviços prestados, um ganho operacional, e consequentemente, um ganho financeiro. $\mathrm{O}$ mercado tende a ter seu quadro de competitividade desenhado, no qual unidades ineficientes reavaliam suas estratégias e até deixam de concorrer naquele segmento, se julgarem necessário. Em contrapartida, uma análise da eficiência de um determinado setor pode servir de atrativo para unidades que se julgam entrantes potenciais em tal segmento, e isso faz com que o mercado se diversifique e adquira certo dinamismo (CAVES et al.,1982).

\subsection{Análise por Envoltória de Dados - DEA}

Ao se tratar de problemas que envolvem o conceito de eficiência relativa, a análise por envoltória de dados (Data Envelopment Analysis - DEA) é uma das técnicas mais aplicadas. Proposta por Charnes, Cooper e Rhodes (CHARNES et al., 1978), esta técnica auxiliou a resolução do problema do cálculo da eficiência relativa. A técnica é baseada em um modelo de programação linear, sistematizada e resolvida com ferramentas computacionais existentes hoje em dia.

A análise por envoltória de dados baseia-se em programação matemática. Representa uma técnica não-paramétrica, pois não utiliza uma mesma função pré-definida para todas as organizações na análise do relacionamento input-output A técnica toma por base um conjunto de dados observados em diversas organizações, denominadas decision making units, ou simplesmente DMU. Tem-se a intenção de avaliar a eficiência de cada DMU, comparando-a com um grupo de referência constituído por outras DMU's com o mesmo conjunto de input e output (SAHA e RAVISANKAR, 2000) - eficiência relativa. A DMU considerada como mais eficiente servirá de parâmetro para o julgamento de todas as outras. Assim, as DMU`s eficientes servem de modelos para pesquisas futuras e de análise de benchmarking (ALMEIDA, MARIANO e REBELATTO, 2007).

A técnica DEA compara um determinado número de DMU, de atribuições similares, mas que diferem entre si pelo montante de inputs que necessitam para realizar seu negóciopropósito, e de outputs que resultam de sua função produção.

O objetivo da técnica DEA é construir um conjunto de referência convexo. Assim, as DMU`s podem ser classificadas em unidades eficientes ou ineficientes, tendo como parâmetro delineador uma fronteira de eficiência. A Figura 2 ilustra o conceito de fronteira de eficiência 
convexa.

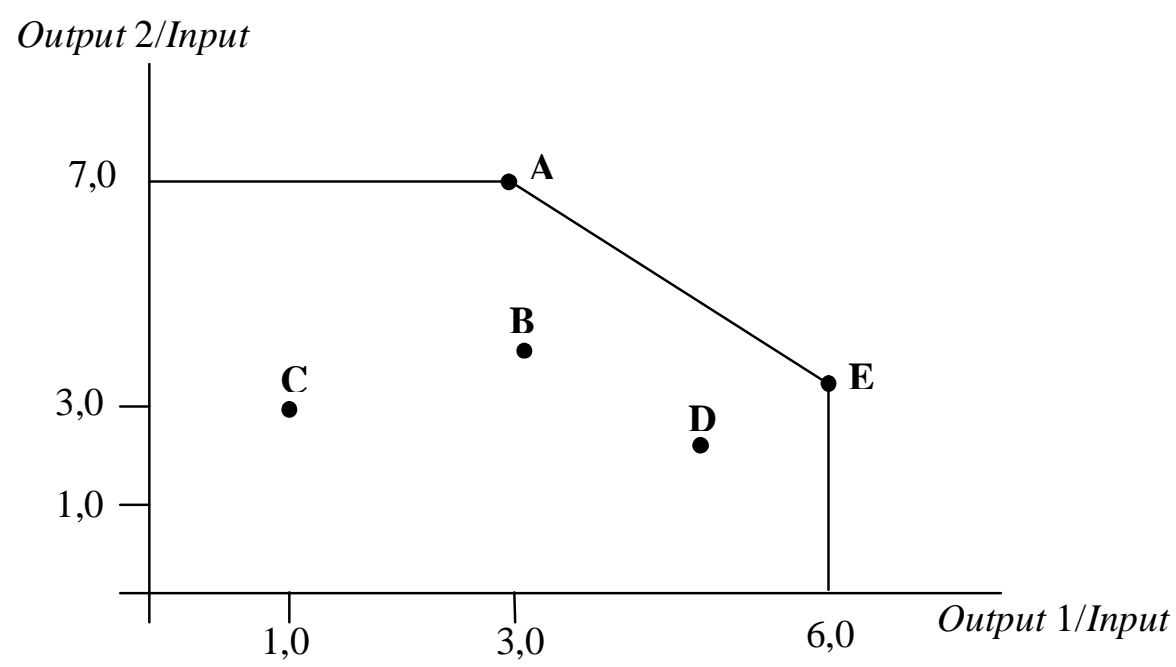

Figura 2 - Gráfico da fronteira de eficiência.

Fonte: Adaptado de Soares de Mello et al. (2005, p.2531).

Vale ressaltar que o termo função produção se aplica para a função que delineia toda e qualquer atividade transformadora. Nesta pesquisa, como exemplo, a função produção está ligada à execução de serviços nas empresas seguradoras do Brasil.

Ao se calcular a eficiência por técnicas que traçam uma fronteira, adota-se a convenção de que as unidades localizadas na fronteira de eficiência são tidas como eficientes. Já as unidades ineficientes se localizam sob a curva de eficiência.

Algebricamente, o cálculo da eficiência adota o conceito de distância. Uma unidade com distância diferente de zero, em relação à fronteira é tida como não eficiente. Se uma unidade possui distância igual à zero, esta é definida como eficiente (CAVES et al.,1982; FARE et al.,1994).

Diversos autores afirmam que, além de identificar as DMU`s eficientes, os modelos de DEA permitem medir e localizar a ineficiência, além de estimar uma função de produção linear por partes, que fornece um benchmark para as DMUs ineficientes (ALMEIDA e REBELATTO, 2007).

Yun et al. (2004) e Charnes et al. (1996) afirmam que as principais características, assim como vantagens, da técnica de análise por envoltória de dados são as seguintes:

- DEA pode ser aplicado para medir múltiplos outputs e inputs, sem utilizar pesos para eles; 
- A análise por envoltória de dados gera um único patamar de desempenho relativo às outras unidades;

- A técnica em questão diferencia as unidades eficientes das ineficientes;

- DEA define os recursos e calcula o nível de ineficiência das unidades ineficientes;

- Mesmo desconhecendo informações sobre a função produção, a técnica DEA ainda pode ser usada para medir a eficiência relativa;

- DEA possibilita a inserção das preferências dos tomadores de decisão;

- A análise por envoltória de dados possui a habilidade de detectar deficiências específicas, que não podem ser detectadas por outras técnicas.

A técnica de análise por envoltória de dados soluciona problemas os quais podem possuir duas orientações: uma orientação para produtos (outputs) ou para insumos (inputs). A orientação para insumos direciona o modelo para uma redução da quantidade de insumos, mantendo o número de produtos constantes. Em contrapartida, uma orientação para os produtos infere em um aumento do número de produtos, mas mantém o número de insumos constante. A Figura 3 é capaz de ilustrar tais conceitos:

Eixo y: Produto

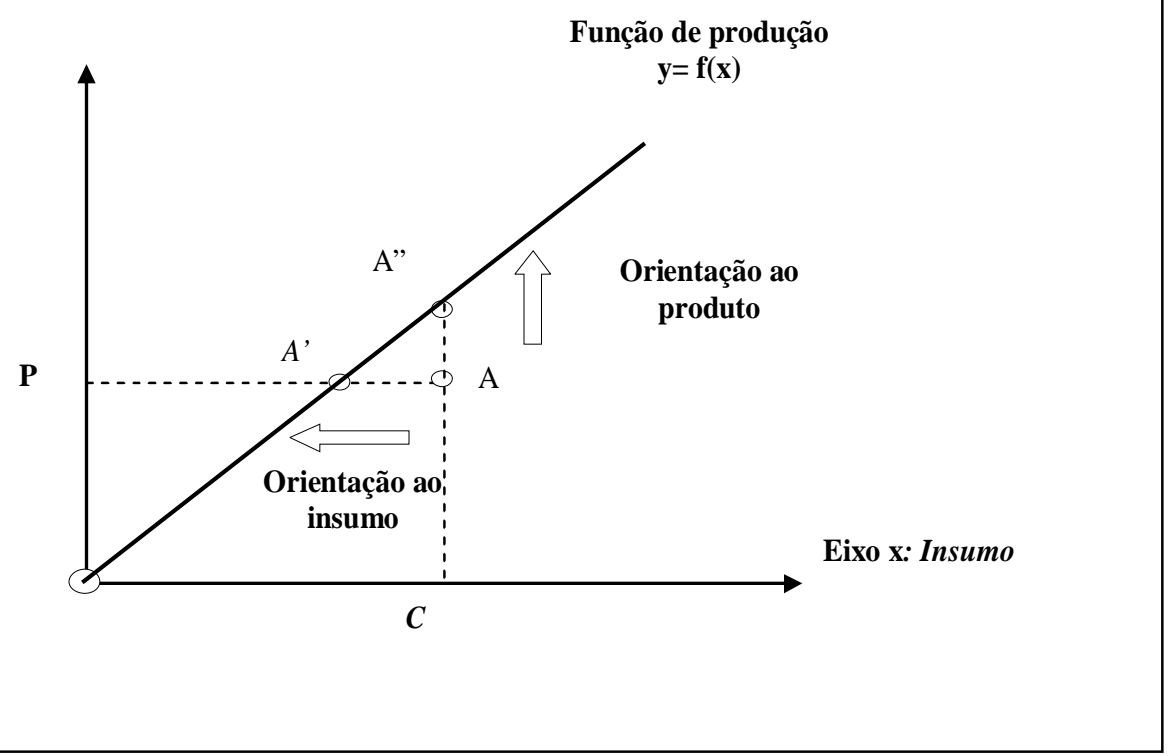

Figura 3 - Modelo CCR de Orientação ao insumo ou ao produto

Fonte: Adaptado de COELLI (1998). 
Assim, essa técnica determina o índice de eficiência de uma DMU, em referência às outras unidades do seu próprio nicho de atuação. Segundo Cooper et al. (2000), a técnica DEA tem origem na Eficiência Pareto-Koopmans, qual afirma que uma organização é completamente eficiente se, e somente se, não for possível aumentar nenhum insumo ou produto sem diminuir algum outro insumo ou produto.

A partir de então, Charnes, Cooper e Rhodes (1978) evoluíram suas pesquisas ao aplicarem múltiplos inputs e outputs, por meio de modelos não-paramétricos denominados DEA com retorno constante de escala, denominado modelo CCR. Tal modelo permite uma avaliação objetiva da eficiência global e identifica possíveis graus de ineficiência das DMU's (CASA NOVA, 2002).

Para se trabalhar com modelos CCR, deve-se utilizar equações voltadas para programação linear, sempre considerando uma função objetivo - a qual deve ser otimizada, e suas devidas restrições. A seguir, demonstra-se um modelo CCR primal orientado ao input.

$M A X=\sum_{i=1}^{m} u_{i} \cdot y_{i 0}$

Sujeito a:

$\sum_{j=1}^{n} v_{j} \cdot x_{j 0}=1$

$\sum_{i=1}^{m} u_{i} \cdot y_{i k}-\sum_{j=1}^{n} v_{j} \cdot x_{j k} \leq 0$, para $k=1,2, \ldots z$

$u_{i}$ e $v_{j} \geq 0$

Sendo:

$u_{\mathrm{i}}=$ peso calculado para o produto $\mathrm{i}$;

$v_{\mathrm{j}}=$ peso calculado para o input $\mathrm{j}$;

$x_{\mathrm{jk}}=$ quantidade do input $\mathrm{j}$ para unidade $\mathrm{k}$;

$y_{\mathrm{ik}}=$ quantidade do produto i para unidade $\mathrm{k}$;

$x_{\mathrm{j} 0}=$ quantidade do input $\mathrm{j}$ para unidade em análise;

$y_{\mathrm{j} 0}=$ quantidade do produto i para unidade em análise; 
$\mathrm{z}$ = número de unidades em avaliação;

$\mathrm{m}=$ número de tipos de produtos;

$\mathrm{n}=$ número de tipos de input; $e$

Banker et al. (1984) propuseram uma nova modelagem para a técnica DEA ao eliminar a necessidade de se obter rendimentos constantes de escala, fato este que deu origem ao modelo BCC, de retorno variável de escala. Tal modelo propõe uma distinção entre ineficiências técnicas e de escala. Estima a eficiência técnica pura, à uma dada escala de operações, e identifica nas DMU's possíveis ganhos de escala (CASA NOVA, 2002).

As equações descrevem um modelo BCC primal orientado aos inputs, com sua função objetivo e suas devidas restrições.

$M A X P O=\sum_{i=1}^{m} u_{i} \cdot y_{i 0}+u$

Sujeito a:

$\sum_{j=1}^{n} v_{j} \cdot x_{j 0}=1$

$\sum_{i=1}^{m} u_{i} \cdot y_{j k}+u-\sum_{j=1}^{n} v_{j} \cdot x_{j k} \leq 0$, para $k=1,2, \ldots z$

$u_{i} e v_{j} \geq 0$

Sendo:

$u_{\mathrm{i}}=$ peso calculado para o produto $\mathrm{i}$;

$v_{\mathrm{j}}=$ peso calculado para o input $\mathrm{j}$;

$x_{\mathrm{jk}}=$ quantidade do insumo $\mathrm{j}$ para unidade $\mathrm{k}$;

$y_{\mathrm{ik}}=$ quantidade do produto i para unidade $\mathrm{k}$;

$x_{\mathrm{j} 0}=$ quantidade do insumo $\mathrm{j}$ para unidade em análise;

$y_{\mathrm{j} 0}=$ quantidade do produto i para unidade em análise;

$\mathrm{z}$ = número de unidades em avaliação;

$\mathrm{m}=$ número de tipos de produtos; 
$\mathrm{n}=$ número de tipos de inputs;

$\mathrm{u}=$ coeficiente de retorno a escala; $\mathrm{e}$

Como qualquer outra técnica, na análise por envoltória de dados existe alguns procedimentos básicos e essenciais são requeridos quando se possui a intenção de se aplicar a técnica DEA. Thanassoulis (2001) afirma que tais procedimentos consistem em:

- As organizações - DMU's devem ser homogêneas, o que se faz necessário que as unidades analisadas realizem tarefas similares e busquem objetivos semelhantes;

- As variáveis devem passar por uma análise de correlação;

- As DMU's devem realizar suas atividades transformadoras dentro de um mesmo ambiente mercadológico; e

- As variáveis (inputs e outputs) devem ser as mesmas para todas as DMU's sob análise, diferenciando apenas em grau de intensidade.

Eventualmente, pode ocorrer o caso de duas DMU's operarem de forma eficiente à um ponto de serem combinadas para assim se obter uma DMU composta - DMU virtual, pois não existe na realidade. Assim, constata-se que a técnica DEA procura sempre atingir o nível ideal de eficiência, seja em uma DMU real ou virtual.

Gomes et al. (2004) citam em seu trabalho a ressalva de que se deve evitar o uso de um modelo que englobe grande número de variáveis sem relação de causalidade. Diversos autores indicam que a relação estabelecida entre as variáveis deve ser entre 4 a 5 vezes superior à quantidade de DMUs, principalmente em casos que se possui a intenção de realizar um benchmarking entre as DMU's. Cooper et al. (2000) definem que o número de DMU's deve ser, pelo menos, três vezes maior que a quantidade de insumo $m$ e produtos $s$. Com base em tais pressupostos, a Expressão 8 define a relação entre a quantidade de variáveis e o tamanho da amostra - quantidade de DMU's.

$n \geq \max \{m \times s ; 3(m+s)\}$

Sendo:

$n=$ número de DMUS; 
$m=$ quantidade de inputs;

$\mathrm{s}=$ número de outputs.

Tratando-se da abrangência da técnica DEA, Dyson et al. (2001) ressalvam algumas constata algumas limitações, que podem ser listadas como a seguir:

- A possibilidade de um número maior de unidades atingirem o desempenho máximo aumenta conforme o crescimento do número de variáveis;

- Para toda e qualquer técnica não-paramétrica, é inviável formular hipóteses de base estatística;

- Devido ao fato de ser uma técnica que depende da alimentação de dados exógenos, a analise é sensível a ruídos, tais como erros de medição ou valores extremos (outliers);

- A técnica DEA analisa o desempenho relativo. Esta converge de forma lenta para o desempenho absoluto, devido ao fato de se basear em dados observados, ao invés de buscar o ótimo supremo e absoluto.

Como já citado, uma região tida como eficiente se fizer render seu output ao máximo, a partir de uma determinada quantidade de inputs utilizados. Há também uma compensação entre unidades eficientes e ineficientes. As unidades eficientes realizam um papel compensador para as DMU's ineficientes, uma vez utilizadas como parâmetro para as demais (FARRELL, 1957).

Tal avaliação demonstra a necessidade de as variáveis de input e output representarem fenômenos do contexto real. Como exemplo, para calcular a eficiência dos sistemas produtivos é necessário que as organizações identifiquem as principais variáveis atuantes no sistema que se pretende analisar.

\subsubsection{Cálculo da fronteira invertida e índice combinado}

A fronteira invertida, segundo Soares de Mello et al. (2005), surgiu da necessidade de solucionar situações de empate entre DMU's que eram classificadas como 100\% eficientes. Segundo Almeida, Mariano e Rebeletto (2006), situações de empate são bastante comuns 
nesses modelos. Segundo Lins e Meza (2000), esses empates são frutos da possibilidade de as DMUs, poderem ser eficientes atribuindo peso nulo a vários multiplicadores, fato este que consistiu por algum tempo em um dos principais problemas do DEA. O uso da fronteira invertida veio preencher esta lacuna e auxiliar na questão de desempatar as DMU's 100\% eficientes.

Diante desta necessidade, foi desenvolvido um índice que realizar um desempate entre as DMU's eficiente e apresentar qual, dentre as analisadas, seria a unidade mais eficiente. De acordo com o conceito de fronteira invertida, a DMU mais eficiente seria aquela que conseguir produzir muito de todos os outputs e gastar pouco de todos os inputs. Não existe a necessidade de que a DMU eficiente se destaque em nenhum especificamente. O que a torna eficiente é o desempenho mais equilibrado quando analisada sob as duas perspectivas fronteira clássica e fronteira invertida. A fronteira invertida busca excluir do grupo ocupado pelas DMU's eficientes as unidades consideradas eficientes devido ao desempenho excelente em apenas um único input ou em apenas um único output.

Com a adoção da análise da fronteira invertida se faz possível obter um índice mais fidedigno à realidade, denominado índice combinado e calculado com base nas fronteiras original e invertida. $\mathrm{O}$ índice combinado fornece mais adequadamente a eficiência das unidades consideradas eficientes nos cálculos matemáticos (SOARES DE MELLO et al., 2005).

A fronteira invertida consiste simplesmente em inverter o racional do modelo, transformando outputs em inputs, e os inputs como outputs. Segundo Almeida, Mariano e Rebelato (2007), pode-se sistematizar o cálculo da eficiência pela fronteira invertida por meio dos passos descritos a seguir.

1. Invertem-se os inputs e os outputs;

2. É resolvido o problema de programação linear;

3. Baseado na perspectiva escolhida, procede-se normalmente, seguindo os mesmos passos adotados com a fronteira clássica, para encontrar a eficiência. Será encontrado um valor definido como a Eficiência Pessimista $E_{\text {pess }}$ das DMU's em análise;

4. Inverte-se o valor da eficiência pessimista encontrada da seguinte forma: $1 / E_{\text {pess }}$. Este valor representa um bom indicador de eficiência. 
5. No entanto, pelo fato de ser maior que 1 , faz-se necessária aplicação de um processo para padronizar os dados em um intervalo de zero à um. Uma opção é adotar o maior valor dentre as eficiências encontradas como parâmetro e aplicá-lo como denominador para a eficiência de todas as DMU's. Assim, obtém-se o índice de eficiência da fronteira invertida $E_{f i}$.

A Figura 4 apresenta um exemplo de uma fronteira invertida comparada com uma fronteira clássica para um modelo BCC.

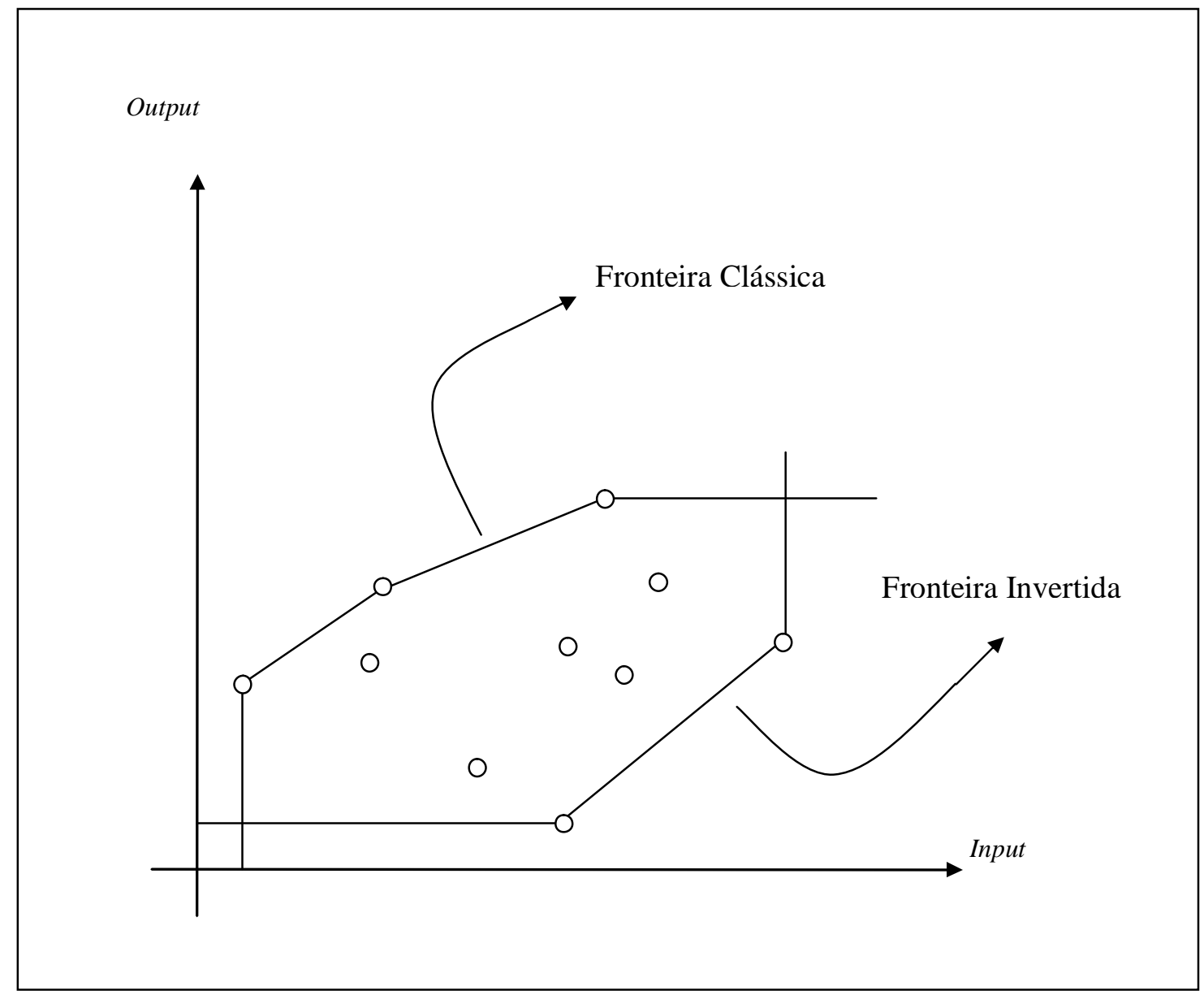

Figura 4 - Fronteira Clássica e Fronteira Invertida

Fonte: Almeida, Mariano e Rebelatto (2007)

Assim, o índice combinado de eficiências da fronteira clássica e da fronteira invertida é capaz de fornecer uma visão de eficiência na qual a DMU eficiente deve ter um bom desempenho nos quesitos em que é a melhor dentre as unidades analisadas, mas sem ter um mau desempenho nos critério em que esta for tida como a pior. $O$ índice de eficiência 
combinada é obtido pela média aritmética entre os dois índices de eficiência.

\subsubsection{Seleção de variáveis}

Além do já difundido teste para avaliar o grau de correlação entre as variáveis de input e output, esta pesquisa utilizará o realizará o método proposto por Norman e Stoker (1991) denominado Stepwise - passo a passo. O método se fundamenta em um par de input-output essencial, calcula o score de eficiência das DMUs em análise com base neste par, e em seguida, determina os coeficientes de correlação de todas as demais variáveis com estes scores. Para dar seqüência a inclusão de mais variáveis, seja ela input ou output, as demais variáveis são gradativamente consideradas no modelo, em ordem decrescente do módulo do coeficiente de correlação.

O método Stepwise predispõe informações que classificam a variável candidata como input ou output, além de estabelecer critérios distintos para a seleção de todas as variáveis contempladas pelo modelo. O resultado da realização deste método é a incorporação de variáveis que venham a propiciar um melhor ajuste das DMUs à fronteira delineada. Em contrapartida, variáveis que não possuam impacto suficiente para alterar significativamente os escores de eficiência também serão identificadas e excluídas do modelo.

De acordo com Lins e Meza (2000), variáveis tidas como elegíveis ao modelo devem ser acrescentadas, e assim define-se o cenário que atingirá a maior eficiência média. A seleção é encerrada ao se adicionar variáveis que não incrementam de forma significativa a eficiência média do modelo.

Este procedimento de seleção das variáveis foi adotado como procedimento para se chegar nos resultados e está descrito detalhadamente na seção que discorre sobre o método utilizado.

\subsection{Aplicações no setor de seguros}

As diversas aplicações da técnica DEA podem ser encontradas nos trabalhos desenvolvidos por pesquisadores como: BANKER et al. (1984) e CHIRIKOS e SEAR (2000) aplicaram DEA para avaliar a eficiência relativa de hospitais; ABBOTT e DOUCOULIAGOS (2003) avaliaram universidades; THANASSOULIS e DUSTAN (1996), escolas; WARD et al. (1997) e CURKOVIC (2003) realizaram o experimento de aplicar a técnica em empresas de manufatura.

Dentro do setor de seguros, existem diversas publicações que utilizam a técnica DEA 
para solucionar problemas dos mais variados tipos. Os assuntos mais comumente discutidos são voltados para a análise da eficiência dos serviços oferecidos.

Cummins et al. (1999) propuseram um modelo para resolver o problema de cálculo da eficiência em operações de fusões e aquisições de empresas, sob o escopo de quão benéfica essas operações são para as partes envolvidas. Este autor realizou sua pesquisa com base em dados de diversos tipos de eficiência do setor de seguros de vida dos Estados Unidos, no período de 1988 a 1995, utilizando DEA. Como resultado, a pesquisa concluiu que as empresas que possuíam uma eficiência considerada como de bom desempenho refletiam de fato em boas opções de corporações para se realizar processos de fusão e/ou aquisição.

Segundo Yang (2005), os dois assuntos mais importantes abordados pela técnica DEA dentro do setor de seguros são voltados para avaliação dos produtos ofertados e avaliação dos investimentos realizados com os fundos de reservas. Seu trabalho, voltado para o mercado de seguros canadense, estudou o desenvolvimento de um modelo de dois estágios, que utiliza a técnica de análise por envoltória de dados para avaliar de forma integrada as performances da produção de serviços e das operações de investimento das reservas técnicas, considerando o comprometimento mútuo entre estas duas operações. Como resultados, Yang observou que as empresas que desempenharam um papel competente em ambas as instâncias operacionais e de mercado de capitais obtiveram um resultado para o score de eficiência.

Tone e Sahoo (2005) aplicaram a técnica DEA com o intuito de examinar o desempenho de empresas prestadoras de serviços de seguros de vida na Índia. Obtiveram o resultado de que existe um caráter de efetiva heterogeneidade dentro das DMUs, variante no tempo e entre as unidades, simultaneamente.

Também procurando explorar a técnica DEA, Kao e Hwang (2006), investigaram a decomposição de um processo de produção de serviços das empresas de seguros de Taiwan em duas etapas - análise operacional e análise financeira, nas quais os outputs do primeiro estágio servem como inputs para a segunda etapa. Os resultados obtidos com este trabalho comprovaram que analisar o universo de empresas seguradoras sob dois escopos diferentes operacional e financeiro, apresenta scores de eficiência diferentes, se comparados com a pontuação oriunda da análise das mesmas unidades considerando indicadores mistos.

Já Yao et al. (2007) ressalvam que a China, mesmo possuindo $22 \%$ da população mundial, dispõe de apenas 3,7\% do total de prêmios arrecadados no mundo, e por isso propõe em seu trabalho calcular scores de eficiência das maiores companhias de seguros da China, e 
identificar fatores determinantes para seus estados de eficiência ou ineficiência. Com este estudo, chegou-se ao resultado de que os fatores determinantes para um eventual estado de eficiência estão mais voltados para espectos econômico-financeiros que para aspectos operacionais. Este fato embasa-se no fato já citado de que o resultado do negócio de seguros privados está diretamente ligado à aplicação das reservas das empresas no mercado de capitais.

Com base em conclusões similares como a disposta logo anteriormente, esta pesquisa busca aplicar DEA em um conjunto de empresas que possuam características em comum, além de pertencerem à um mesmo setor e exercerem atividades semelhantes.

Assim, o trabalho se beneficiará da técnica de análise por envoltória de dados ao utilizá-la para elaborar um ranking das empresas seguradoras atuantes em território nacional. Uma das questões a serem respondidas é: São as empresas de desempenho uniformes na maioria das variáveis consideradas mais eficientes que as empresas que obtiveram desempenhos excelentes e alguns poucos indicadores?

O capítulo a seguir explora a segunda técnica utilizada neste trabalho, denominada de Redes Neurais Artificiais. 


\section{CAPÍTULO 3 - REDES NEURAIS ARTIFICIAIS}

Este capítulo apresenta e discute os principais aspectos da técnica de Redes Neurais Artificiais. Ao longo de seu desenvolvimento, serão explorados conceitos gerais, aplicações, histórico de evolução e, de uma maneira mais completa, as particularidades da arquitetura de rede que será aplicada neste trabalho.

\subsection{Modelos Neurais Artificiais}

A literatura pertinente ao campo da Pesquisa Operacional demonstra diversos métodos matemáticos que podem ser utilizados na solução de problemas não lineares e na otimização de seus resultados. Existe uma gama de procedimentos paramétricos para analisar dados, tratá-los e, a partir daí, extrair as informações necessárias para a solução de problemas e/ou a tomada de decisão. Dentre os métodos existentes, pode-se mencionar:

- Método de Box-Jenkings: estudo da evolução de uma ou mais variáveis ao longo do tempo e representação de modelos comportamentais por meio do inter-relacionamento entre as variáveis denominadas dependentes e independentes (GUJARATI, 2000);

- Análise Multivariada: técnica estatística que estuda o relacionamento das variáveis que compõem arranjos matriciais e que tem como aplicação relevante a criação e análise de clusters;

- Modelos Heterocedásticos ARCH-GARCH - modelo dos mínimos quadrados: ferramentas que se adaptam de acordo com o comportamento da hipótese estatística de variância constante nos dados de uma variedade de amostras de uma população (ENGLE, 2001).

Entretanto, quando se aprofunda o estudo de métodos como referidos acima, constatase que mesmo diante da obtenção de resultados palpáveis e coerentes, eles apresentam alguns entraves operacionais como a dificuldade de se desenvolver modelos estatísticos complexos, a existência de hipóteses restritivas a serem postas à prova, e, sobretudo, a dificuldade de 
compreensão por aqueles que não são especialistas no assunto, mas que demandam por resultados que tais métodos podem fornecer.

Existem duas abordagens tradicionais para a determinação da eficiência de uma unidade produtiva, segundo Farrell (1957): a abordagem paramétrica e a abordagem nãoparamétrica (BUTTON; WEYMAN-JOHNES, 1992; LINS; MEZA, 2000; SOUZA, 2003).

Os modelos paramétricos podem ser definidos como modelos descritos a partir da expressão linear, dados seus coeficientes (GILLEN; LALL, 1997; SOARES MELLO et al., 2005).

Os modelos não-paramétricos são caracterizados como modelos que não apresentam coeficientes e dispõem os dados apenas na fase posterior à resolução do problema. Tais modelos se baseiam em programação matemática e têm o objetivo de construir fronteira de produção (SENGUPTA,1989). Uma vantagem do método não-paramétrico consiste na sua flexibilidade, já que se adapta a sistemas com entradas variadas e delimita um número menor de restrições voltadas para o método de solução (GILLEN e LALL, 1997).

Algumas das diferenças pertinentes entre os dois modelos são delineadas abaixo:

- Modelos paramétricos não utilizam dimensões restritas, nem cumprem premissas para a aplicação de algumas arquiteturas de redes neurais;

- Modelos paramétricos não têm restrição quanto ao tamanho da amostra;

- Os dados de modelos paramétricos podem ter baixa ou alta correlação para ser interpretado, o que influi diretamente na interpretação do resultado;

- Modelos não-paramétricos podem trabalhar com um variado montante de atributos de entrada;

- Modelos não-paramétricos podem trabalhar com reduzidas amostras de dados, sem perder qualidade na análise dos resultados;

Segundo Silva et al. (2004), atualmente, há uma demanda crescente por estudos sobre métodos que utilizem arquiteturas de processamento paralelas e adaptativas, com o objetivo de incrementar a performance dos modelos de solução de problemas. Redes neurais artificiais se encaixam em tal perfil demandado, visto que possuem, dentre seus diversos atributos, a capacidade intrínseca de operar em paralelo, a relativa simplicidade de serem implantadas em 
ambiente computacional e o alcance de altas taxas de computação mediante elementos simples de processamento.

A principal diferença entre abordagens estatísticas convencionais e redes neurais consiste em que as redes neurais não estabelecem hipóteses ou suposições sobre a distribuição ou propriedades dos dados. Assim, sem pré-julgamentos, a rede tende a ser mais útil em situações práticas. Modelos neurais também abordam problemas não lineares e fornecem uma considerável precisão diante da modelagem com base em dados complexos ou ainda incompletos. Existem vários tipos de redes, cada uma com diferentes objetivos, arquitetura e algoritmo de aprendizagem (SMITH e GUPTA, 2000).

Os modelos neurais são capazes de realizar a aproximação de qualquer função contínua e também são capazes de generalizar os resultados obtidos para dados não utilizados, mas que possam vir a ser inseridos no modelo. Portanto, modelos neurais podem produzir respostas coerentes e adequadas para uma diversidade de dados, ainda que não utilizados durante a fase de treinamento (FAUSETT, 1994; HAYKIN, 1994; BISHOP, 1995).

\subsection{Definição de Redes Neurais Ariticiais}

De acordo com Mehrotra (1997) e Chester (1993), redes neurais artificiais são técnicas computacionais que apresentam um modelo matemático análogo à estrutura neural dos seres vivos, adquirindo assim conhecimento mediante experiências. São modelos computacionais inspirados no cérebro humano e que possuem a capacidade de aquisição e manutenção do conhecimento. Consistem em um conjunto de unidades de processamento análogos ao neurônio biológico, que se interligam mediante a troca de sinais, também análoga à sinapse biológica.

Dentre as características distintivas dos modelos neurais computacionais apresentadas na literatura existente, as principais são as seguintes:

- Capacidade de aprender por meio de exemplos;

- Capacidade de adaptação;

- Agrupamento e organização de dados;

- Tolerância à falhas;

- Auto-organização;

- Capacidade de generalização. 
Portanto, as redes neurais artificiais podem ser compreendidas como um sistema projetado para modelar problemas complexos lineares ou não lineares, com base no funcionamento do cérebro humano. A rede artificial é normalmente implantada utilizando-se componentes eletrônicos ou é simulada por programação em um computador digital (HAYKIN, 2001).

Dentre as propriedades circunscritas por redes neurais artificiais, merecem destaque a não-linearidade e a capacidade de aprendizado. A não-linearidade é a propriedade atribuída aos modelos neurais devido ao comportamento não-linear dos neurônios da rede, devido ao fato de grande parte dos problemas possuírem caráter não linear. Exemplos desses problemas podem ser atribuídos à solução de problemas voltados para reconhecimento de voz e memórias associativas, aplicações bem difundidas no assunto. A capacidade de aprendizado representa a capacidade da rede de aprender sobre os dados por ela manipulados durante um período de treinamento.

\subsection{Evolução Histórica}

As redes neurais artificiais surgiram da evolução dos estudos em Pesquisa Operacional e configuram um sub-ramo da Inteligência Artificial que, como já mencionado anteriormente, se dispõe a simular, em um ambiente computacional, o comportamento do cérebro humano. Segundo Kohonen (1987), modelos neurais análogos ao comportamento do cérebro humano eram inicialmente propostos como alinhados às teorias psicológicas e pesquisas neurofisiológicas. Mas foi a partir da pesquisa desenvolvida por McCulloch e Pitts (1943) que se começou a fundamentar com uma maior precisão o alinhamento entre computação e modelos neurais.

McCulloch e Pitts (1943) sugeriu a construção de uma máquina inspirada no cérebro humano, denominada Psychon, e que se baseava em um modelo matemático (artificial) do neurônio biológico. Os frutos da pesquisa de McCulloch e Pitts voltaram-se mais para a descrição de um modelo artificial de um neurônio e a apresentação de suas capacidades computacionais, deixando em segundo plano as técnicas de aprendizado.

Portanto, a literatura é unânime em considerar como marco inicial dos estudos sobre modelos computacionais baseados em sistemas neurais o trabalho de McCulloch e Pitts, publicado em 1943. Neste trabalho, os autores apresentaram o primeiro modelo de neurônio 
artificial baseado em modelagem matemática para simular o comportamento do neurônio biológico. Tal modelo representa até hoje a principal ferramenta utilizada nas arquiteturas de redes neurais artificiais disponíveis.

De acordo com Hebb (1949), em "The Organization of Behaviour" foi proposto uma lei de aprendizagem específica para as sinapses dos neurônios. A partir de então, passou-se a buscar um modelo capaz de proporcionar similar capacidade de aprendizado às redes neurais artificiais.

Em 1951, Marvin Minsky construiu o primeiro neurocomputador, denominado Snark. Essa unidade não estava apta a executar qualquer função de processamento de informação pertinente, mas tinha bom desempenho na atividade de ajuste de pesos sinápticos, e serviu de parâmetro para as pesquisas que a sucederam. Já Farley e Clark (1954), apresentaram modelos para respostas aos estímulos adaptativos em redes aleatórias, o que significou uma evolução neste campo do conhecimento.

No ano de 1956, ocorreu a difundida reunião no Darthmouth College, que marcou o fim da Era Romântica da pesquisa sobre redes neurais artificiais e deu início à Era Barroca (BARRETO, 1997). Em tal evento, foi identificada a potencialidade dos modelos neurais em ambiente computacional e surgiram os dois paradigmas cultuados pela Inteligência Artificial. O primeiro deles consiste na Inteligência Artificial Simbólica que se propõe a simular o comportamento inteligente humano, desconsiderando os mecanismos pelo qual a inteligência biológica se apóia - capacidade e eficiência relativa do cérebro. O segundo paradigma, a Inteligência Artificial Conexionista, afirma que, uma vez construído um sistema que simule a estrutura do cérebro, este se mostra inteligente e, assim, capaz de errar, aprender e assimilar informações.

Posteriormente, Rosenblatt (1958) apresentou o primeiro neurocomputador a obter sucesso efetivo, denominado Mark I Perceptron, que dispunha de uma rede neural de duas camadas de neurônios capazes de aprender de acordo com a lei de Hebb. Em seguida vieram os trabalhos de Widrow e Hoff (1960), Caianiello (1961) e de Steinbuch (1961) que agregaram valor às pesquisas realizadas até então sobre o assunto. Contemporaneamente, foi desenvolvido por Widrow em 1962 a modelagem Adaptive Linear Element - Adaline, um tipo de processamento neural que possui uma lei de aprendizado eficaz e que é bastante usada até os dias de hoje. Tanto o Perceptron quanto o Adaline se baseiam no aprendizado supervisionado por correção de erros, forma de aprendizagem difundida entre diversas arquiteturas de modelos neurais e bastante aplicada atualmente. 
Tais publicações parcialmente explicam o considerável número de trabalhos e aplicações em computação neural em torno da década de 60. Porém, vale ressaltar que as limitações tecnológicas limitavam o ritmo do avanço das pesquisas sobre o assunto objeto deste trabalho.

Minsky e Papert (1969) publicaram o livro intitulado "Perceptrons: An Introduction to Computational Geometry", no qual demonstraram matematicamente que a rede proposta anteriormente por Rosenblatt (1958) não era capaz de distinguir padrões linearmente separáveis, como a solução de questões envolvendo o impasse OU-EXCLUSIVO. A obra desses autores funcionou como uma barreira para o ritmo em que as pesquisas em redes neurais artificiais vinham evoluindo, uma vez que questionou os fundamentos que embasavam as teorias existentes. Tal fato encerrou a Era Barroca e deu início a denominada Era das Trevas, que duraria até meados de 1981.

Como próximo evento relevante, tem-se o surgimento de um modelo de rede criado por John Hopfield, que operava de uma maneira diferente dos modelos oriundos do Perceptron. A proposta de Hopfield consistiu em uma rede com conexões recorrentes e de comportamento baseado na competição entre os neurônios e de aprendizado não supervisionado. Este modelo definiu as propriedades associativas de uma classe de redes neurais com fluxo de dados multidirecional e comportamento dinâmico (HOPFIELD, 1982).

Nos anos de 1986 e 1987 atinge-se o auge da era contemporânea, com o surgimento de contribuições relevantes como os trabalhos de Rumelhart, Hinton e Williams, Hopfield, Kohonen, dentre outros. A partir desses construtos, descobriu-se como treinar as redes neurais mediante o uso do algoritmo Back Propagation, proposto inicialmente por Paul Werbos em 1974, em sua dissertação para a obtenção do título de Ph.D na Universidade de Harvard.

Para solucionar o problema OU-EXCLUSIVO que havia ofuscado o modelo Perceptron, em 1986 foram desenvolvidas as redes multicamadas. Nesta, seria utilizado o algoritmo Back Propagation uma vez melhor fundamentado por Rumelhart, Hinton e Williams. Tal algoritmo solucionou diversos problemas de aprendizado surgidos ao longo da evolução da neurocomputação e veio a se tornar o algoritmo de aprendizagem mais popular para o treinamento de arquiteturas Perceptrons de múltiplas camadas.

Outros modelos pertinentes que contribuírem para o estado da arte da neurocomputação foram os modelos de Kohonen e os modelos Adaptative Ressonance Theory - ART. O modelo dos Mapas Auto-Organizáveis de Kohonen, ou ainda redes Self Organized 
Maps - SOM, permite o aprendizado competitivo por meio da auto-organização da rede neural ao criar os mapas de atributos auto-organizáveis. O modelo ART foi concebido por Gail Carpenter e Stephen Grossberg e possui um aprendizado do tipo não-supervisionado, criando clusters dos padrões aprendidos. Tal modelo teve diversas versões posteriores, entre elas versões do tipo semi-supervisionado e com uso de conceitos de lógica nebulosa (FuzzyART).

Desde a década de 80, modelos neurais computacionais vêm ganhando popularidade e estão cada vez mais sendo utilizados em sistemas de apoio à decisão. Suas áreas de atuação variam desde filosofia, passando por estatística, reconhecimento de sinais, previsões e engenharia de uma forma geral. Em 1987, ocorreu a primeira conferência de redes neurais em tempos modernos, a International Conference on Neural Networks - IEEE. Formou-se também International Neural Networks Society - INNS e, como decorrência desse evento, foi fundado o INNS Journal.

Atualmente, os estudos em redes neurais artificiais encontram-se em estado avançado de evolução e um vasto campo de pesquisa pode se beneficiar de suas realizações. Existe uma vasta gama de arquiteturas, ferramentas de softwares e bibliografia informativa que auxiliam o processo de solução de problemas cada vez mais complexos, aumentando a eficiência do processo de tomada de decisão por parte das pessoas, organizações e países.

\subsection{Possíveis Aplicações}

Kohonen (1988) cita algumas áreas passíveis de aplicações da técnica de redes neurais artificiais. A primeira delas representa a possibilidade de se reconhecer padrões dentro de uma amostra. A rede atribui um padrão de entrada a uma das várias classes pré-definidas. Tais aplicações possibilitam o reconhecimento de imagens, bastante difundido na medicina, assim como análises de concessões de crédito.

Outra aplicação para modelos neurais consiste em se definir clusters ou categorias de agrupamento. O modelo explora semelhanças entre os padrões e agrupa os similares em classes. Tal aplicação é utilizada para data mining, compressão de dados e, também, para problemas particulares de reconhecimento de padrões. Este trabalho se propõe a utilizar essa aplicação de modelos de redes neurais artificiais para agregar valor ao campo do conhecimento no qual está inserido. 
Quando utilizado como aproximador de funções, o modelo neural tem a tarefa de encontrar uma estimativa " $y$ " de uma função desconhecida "f”. O aproximador de funções neural tem aplicação em diversos problemas de modelagem científica e de engenharia, de uma forma geral. Já problemas de previsão e estimação usufruem de modelos neurais que possuem como tarefa prever o fator " $x$ " futuro fora do domínio de uma determinada função, com base em um conjunto de exemplos.

O Quadro 1 apresentado a seguir, enumera um conjunto de exemplos de aplicação das redes neurais artificiais para a solução de problemas de previsão no campo das finanças:

\begin{tabular}{|c|c|c|}
\hline ANO & TRABALHO & OBJETO DE ESTUDO \\
\hline 1990 & Schoneburg (1990) & $\begin{array}{c}\text { Cotação dos preços das ações no mercado alemão para empresas } \\
\text { como a Basf, Commerzbank, e Mercedes. }\end{array}$ \\
\hline 1992 & Chakraborty et al. (1992) & $\begin{array}{c}\text { Preço da farinha de trigo na cidade de Buffalo, Minneapolis e } \\
\text { Kansas. }\end{array}$ \\
\hline 1999 & Ormoneit (1999) & Cotação dos derivativos no mercado alemão. \\
\hline 2005 & Enke e Thawonwong (2005) & Índice S\&P 500. \\
\hline 2005 & Teräsvirta et al.(2005) & Índices de preço ao consumidor para países do G7. \\
\hline 2006 & Andreou et al. (2006) & Índice S\&P 500. \\
\hline 2006 & Bodyanskiy e Popov (2006) & $\begin{array}{l}\text { Volatilidade do índice Dow Jones para o retorno industrial } \\
\text { médio. }\end{array}$ \\
\hline 2006 & Haofei et al. (2006) & Preços dos produtos alimentícios na China. \\
\hline 2006 & Hassan et al. (2005) & $\begin{array}{c}\text { Índices de preços para as empresas americanas do setor de } \\
\text { tecnologia. }\end{array}$ \\
\hline 2006 & Huarng e Yu (2006) & Cotações no mercado de ações para Taiwan desde 1991 a 2003. \\
\hline 2006 & Malik e Naserredin (2006) & Preço da cotação do barril de petróleo. \\
\hline 2006 & Pao $(2006)$ & Preço para o mercado europeu de energia elétrica. \\
\hline 2006 & (Xuefeng et al. (2006) & Cotação dos preços em sites populares da China. \\
\hline
\end{tabular}

Problemas de otimização também estão inseridos na abrangência da aplicação dos modelos neurais. Estes podem ser aproveitados quando se pretende minimizar ou maximizar uma função sujeita a um conjunto de restrições. Também são relevantes as aplicações em memórias associativas, onde a técnica de rede neural é capaz de recuperar itens de maneira completa mediante a entrada parcial ou incompleta de dados - recuperação de imagens, bases de dados e identificação de curvas.

De um modo geral, as redes neurais artificiais podem ser aplicadas dentro da ciência econômica em detecção de fraudes em sistemas de crédito, avaliação de bolsas de valores, avaliação de crédito em transações comerciais, dentre outros. De uma ótica gerencial, pode-se usar uma RNA para controlar processos industriais, gerenciar linhas de produção, em planejamento para controle de produção, controle de qualidade e sistemas de apoio à decisão 
(KOSKO, 1992; ZURADA, 1992; SOUCEK, 1991; MORGAN e SCOFIELD, 1991; SIMPSON, 1990).

Como este trabalho se propõe a aplicar a técnica estudada para elaborar uma classificação de empresas a partir em um banco de dados composto por indicadores financeiros, pode-se afirmar que será utilizado o conhecimento sobre redes neurais artificiais no campo financeiro. Wong et al. $(1995,1998,1997,2000)$ realizaram um extenso levantamento de publicações na área de sistemas inteligentes, que utilizam as RNAs, desde 1977, a fim de identificar os principais tipos de problemas em que se aplicam redes neurais artificiais. A representação de finanças como uma área de estudo é expressiva conforme demonstrado na Tabela 2.

\begin{tabular}{cccc}
\hline ANO DE & PERÍODOS & $\mathbf{N}^{\mathbf{0}}$. DE ARTIGOS & REPRESENTAÇÃO DE \\
PUBLICAÇÃO & ANALISADOS & ANALISADOS & FINANÇAS \\
\hline 1995 & $1977-1993$ & 326 & $85,80 \%$ \\
1997 & $1988-1995$ & 213 & $78,90 \%$ \\
1998 & $1990-1996$ & 64 & $98,48 \%$ \\
2000 & $1994-1998$ & 302 & $22,18 \%$ \\
\hline
\end{tabular}

Tabela 2 - Representação da área de finanças nas pesquisas de sistemas inteligentes

\subsection{Construtos de uma Rede Neural Artificial}

\subsubsection{Categorias de Redes Neurais Artificiais}

Kohonen $(1990,1997)$ determinou três categorias para a classificação das RNA`s, com base na arquitetura e no tipo de processamento do sinal empregado. São elas:

- Redes de transferência de sinais: transformam um conjunto de sinais de entrada $\mathbf{x}$ em um conjunto de sinais de saída $\mathbf{y}, f: x \rightarrow y$, onde a transformação $\mathrm{f}$ é paramétrica e definida por funções de base ajustadas por treinamento supervisionado. Exemplos incluem redes neurais de múltiplas camadas (RUMELHART et al., 1986) e redes de base radial - RBF (BISHOP, 1995);

- Redes de transferência de sinais: redes recorrentes, nas quais o padrão de entrada define um estado inicial de atividade e após alguns estados de transição, obtêm-se enfim um estado estável, que é identificado como o resultado da operação. Cabem nesta classificação as redes de Hopfield (HOPFIELD e TANK, 1986); 
- Redes Neurais Competitivas: todos os neurônios recebem entradas iguais, de uma forma generalizada. Os neurônios vizinhos competem entre si via interações laterais. Cada neurônio, ou ainda cada grupo destes, desenvolve-se de forma adaptativa em detectores de padrões diferentes, que opera como um decodificador de diferentes domínios do espaço vetorial de entrada. De uma forma geral, são treinadas de forma não supervisionada e denominadas de redes auto-organizáveis. Como exemplos, cita-se o modelo Adaptative Resonance Teory - ART (CARPENTER e GROSSBERG, 19987), e as redes Self Organized Maps - SOM (KOHONEN, 1982; 1997).

\subsubsection{Analogia entre o neurônio computacional e o neurônio biológico}

O sistema nervoso que compõe os seres humanos é formado por um vasto conjunto de células denominadas neurônios. Os neurônios são responsáveis pelo funcionamento do corpo humano como um todo, sendo também as unidades realizadoras do raciocínio. Os neurônios se comunicam entre si viabilizado por um fenômeno denominado sinapse, na qual dois neurônios realizam contato e assim transmitem impulsos nervosos mutuamente. Esses impulsos nervosos recebidos dão origem aos neuro-transmissores, que são os verdadeiros transportadores de dados entre os neurônios.

De uma perspectiva analógica, uma rede neural artificial é composta por várias unidades de processamento, também denominadas neurônios. Pesos numéricos, análogos às sinapses, fazem a conexão entre neurônios e assim determinam a forma como o impulso de saída atuará na unidade seguinte ao ser recebido.

Assim, a rede neural artificial é composta por pequenas unidades que simulam o funcionamento de um neurônio. Estas unidades devem funcionar de maneira similar aos neurônios biológicos a partir dos quais foram inspirados, trocando informações mediante a propagação de impulsos.

Um neurônio artificial deve operar sob as características de primeira ordem de um neurônio biológico. De maneira geral, um conjunto de entradas é aplicado ao neurônio artificial, cada uma delas representando a saída de outros neurônios. Cada entrada é multiplicada por um peso correspondente $w_{i j}$, gerando entradas ponderadas, de forma análoga à força das sinapses. Posteriormente, todas estas entradas ponderadas são somadas, obtendose um valor que será então comparado com o valor limite para ativação do neurônio. Caso o 
valor limite de ativação do neurônio seja alcançado, este se ativará. A Figura 5 ilustra um neurônio computacional e seus parâmetros.

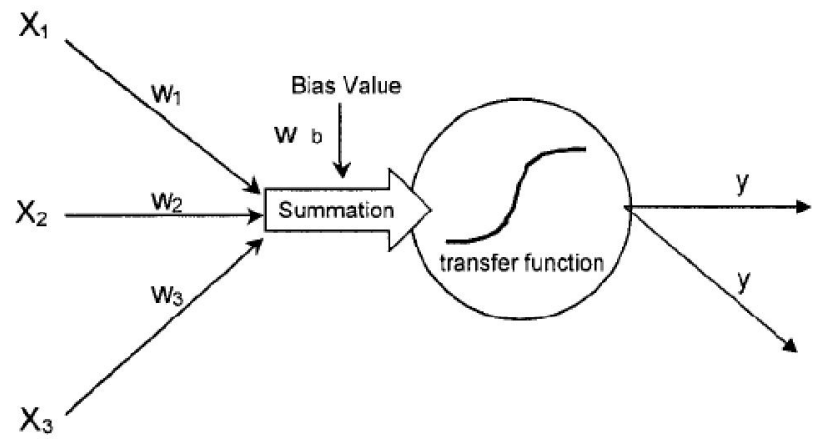

Figura 5 - O neurônio computacional.

Fonte: Adapado de GAMITO et al., (2003).

O neurônio computacional foi originado a partir do neurônio desenvolvido por McCulloch, um dos autores que contribuíram de forma considerável para a evolução da neurocomputação.

\subsubsection{Elementos de uma rede neural}

Uma rede neural pode ser visualizada mediante um conjunto de nós conectados por um conjunto de ligações, uma estrutura distribuída e paralela de processamento de informações. A Figura 6 representa uma rede neural multicamadas genérica.

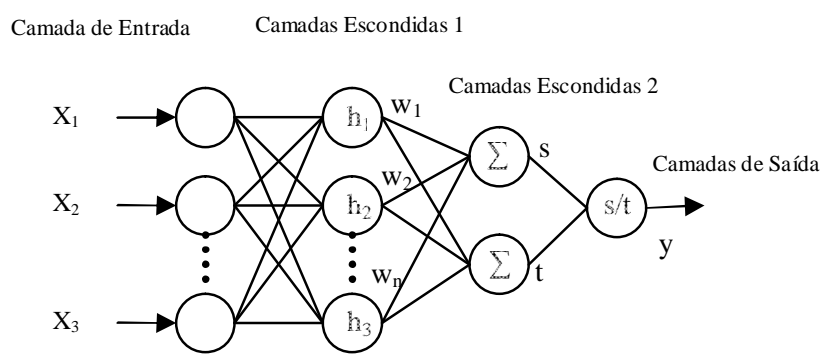

Figura 6 - Rede neural multicamadas: representação genérica.

Fonte: Adaptado de Enke e Thawornwog (2005).

Os elementos de uma rede neural artificial podem ser listados da seguinte forma:

- Nós: são os elementos também denominados de unidades de processamento;

- Conexões da rede: cada conexão funciona como um caminho unidirecional de condução instantânea de impulso entre os nós; e 
- Pesos sinápticos: representadas por vetores $w_{i j}$, que representam a intensidade de interação do nó de posição $i$ com o nó de posição $j$.

O sinal de $w_{i j}$ indica estado de excitação se positivo, ou estado inibitório de dotado de valores negativos, com as seguintes características:

- Cada nó é capaz de receber $n$ conexões de entrada;

- Cada nó pode conectar-se com $n$ outros nós. O sinal emitido para todos esses outros nós é o mesmo;

- Cada nó pode ter uma memória local;

- Cada nó possui um estado de ativação; e

- Os sinais de entrada e de saída de uma rede neural são adquiridos e enviados, via conexões.

Os neurônios se agrupam em camadas, as quais consistem de uma matriz uni ou bidimensional de nós. As camadas podem ter quaisquer configurações geométricas e os nós que as compõem podem se conectar com outros nós da mesma camada ou ainda de camadas diferentes (HAYKIN, 2001).

\subsubsection{Funções de Ativação}

Os neurônios propagam seus sinais de forma seqüencial, de modo que a saída ponderada de uma unidade de processamento representa a entrada na unidade de processamento seguinte. $\mathrm{O}$ sinal transmitido deve ser representativo o suficiente para que a unidade seguinte seja estimulada a continuar transmitindo aquele impulso, senão a transmissão entre as unidades será interrompida..

Para que o neurônio artificial opere de forma similar ao neurônio biológico, se faz necessária a exploração de três parâmetros. São eles estado de ativação, função de ativação e limiar de ativação. $\mathrm{O}$ estado de ativação, que se equivale à freqüência de descarga do neurônio biológico, indica em qual forma os dados de entrada podem estar dispostos para que a rede se 
torne capaz de processá-los. Estes dados podem estar em forma binária (o ou 1), bipolar (-1 ou +1 ), ou ainda em números reais.

A função de ativação é responsável por processar o conjunto de entradas recebidas e o transforma em estado de ativação. É gerado o dado de saída da unidade de processamento quando esta atinge o seu estado de ativação. A ativação do neurônio se dá por meio da aplicação de funções matemáticas das mais diversas operações. A função básica de um neurônio é somar as entradas e retornar uma saída, caso esse valor seja maior que o valor de soma.

Portanto, a função de ativação tem como objetivo processar os sinais provenientes da etapa anterior recebidos por cada neurônio e transformá-los em um estado de ativação neural. Os neurônios artificiais transformam os dados de entrada por meio da aplicação de uma função escalar e geram o valor de ativação que será propagado para a unidade de processamento seguinte.

O limiar de ativação é representado pelo valor oriundo da função de ativação. Este parâmetro determina a dimensão que este valor deve ter para que o neurônio inicie ou não sua atividade. Se o valor do limiar não for suficiente para estimular o neurônio a iniciar suas atividades, este permanecerá inoperante.

Existe a necessidade de se limitar os valores de saída da rede e de se determinar um valor para o limiar de ativação que seja parâmetro para que o neurônio selecione a propagação ou não-propagação do sinal adiante, usam-se funções que não sejam iguais à função identidade. Ao se usar uma função identidade ou ainda uma função linear a unidade não realizará o processamento de seu dado de entrada, pois a unidade de processamento se anulará. Portanto, cabe à técnica de redes neurais artificiais uma característica estritamente experimental, na qual o uso de diferentes funções de ativação irá gerar diferentes sinais de saída possibilitando assim a escolhe daquela que melhor se ajustar ao modelo e apresentar os resultados mais coerentes.

Na Figura 7, o sinal NET é processado pela função de ativação F que transforma o dado de entrada na informação de saída da unidade processadora e assim atinge o estado de ativação exigido pelo neurônio. 


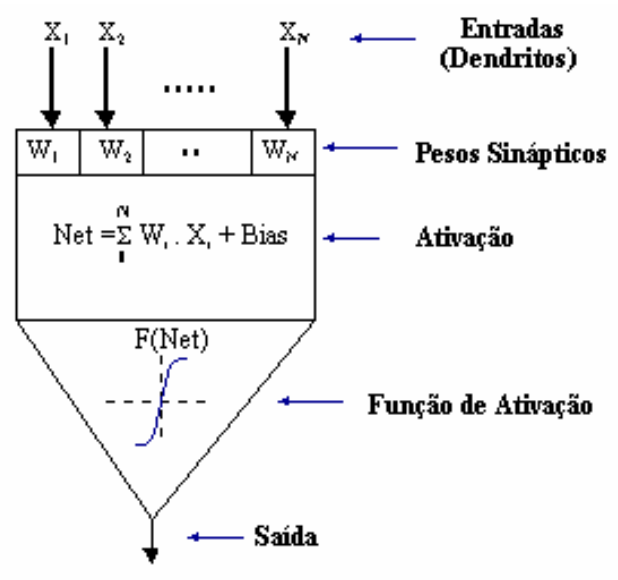

Figura 7 - Representação de um neurônio artificial Fonte: Osório e Bittencourt (2000), p. 02.

A função de ativação pode assumir diversas formas, sejam elas uma simples função linear, uma função degrau ou ainda uma função que simule com uma maior precisão as características não lineares do neurônio biológico.

Se a função $\mathrm{F}$ for uma função linear, a saída do neurônio é resultado da seguinte expressão:

$S A I ́ D A=K \times N E T$

Sendo:

$\mathrm{K}=$ constante

Em outra instância, se F for representada por uma função degrau, tem-se a saída por:

SAÍDA $=1$ se NET $>L$

[12]

$S A I ́ D A=0$ se $N E T \leq L$

Sendo:

$\mathrm{L}=$ limiar do neurônio artificial (constante)

Existem funções não lineares que representam modelos neurais com uma maior similaridade ao neurônio biológico. Tais funções impedem que a saída gerada assuma valores excedentes aos valores limites da rede, normalmente menores que os valores de NET. A 
função mais comum e que se encaixa nessa classificação é a função logística sigmoidal, uma função diferenciável e crescente e bastante utilizada quando se usa números reais. Pode-se representar uma função logística sigmoidal pela seguinte expressão matemática:

$F(x)=1 /\left(1+e^{-\beta \mu}\right)$

Dentro da nomenclatura disposta no neurônio artificial acima, pode-se representar a função por:

$S A I ́ D A=1 /\left(1+e^{-n e t}\right)$

A Tabela 3 traz uma explanação geral das funções utilizadas para o treinamento de redes neurais. A escolha da função de ativação é uma etapa bastante importante do processo de elaboração de um modelo neural, e uma boa escolha depende pertinentemente da experiência do pesquisador. Para cada função existe um conseqüente comportamento adotado pelos dados e também uma forte conexão com a natureza do problema que se propõe a resolver. 


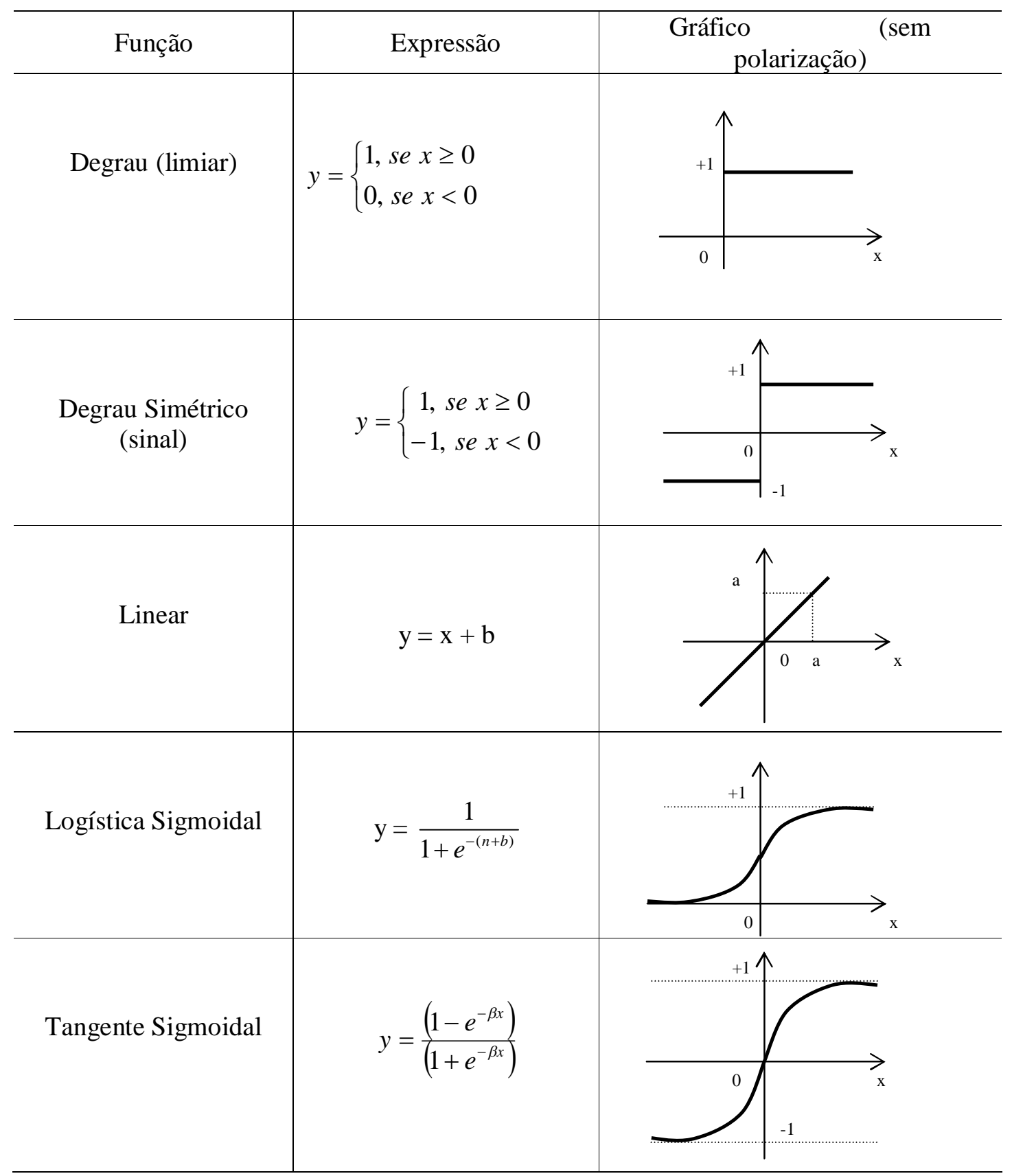

Tabela 3 - Funções de ativação

Entretanto, mesmo com diversos mecanismos para tentar se aproximar ao máximo do neurônio biológico, o neurônio artificial se difere quanto à incapacidade de se considerar atrasos de tempo extrínsecos ao sistema, pois as entradas geram saídas instantaneamente (HEBB, 1949; CARPENTER e GROSSBERG, 1987). 


\subsubsection{Arquitetura vrs. Topologia}

A arquitetura de uma rede neural artificial representa a maneira como os neurônios estão organizados, e está fortemente relacionada com o algoritmo utilizado para treinar e testar a rede.

De acordo com o problema que se pretende determinar uma solução, as arquiteturas de modelos neurais podem ser compostas por algumas estruturas genéricas ou ainda compostas por estruturas particulares, voltadas para funções específicas.

Segundo Haykin (2001), as estruturas genéricas são as conexões entre as unidades de processamento e o arranjo entre as camadas de neurônios da rede - topologia. Braga et al. (2000) afirmam que os atributos básicos de um processamento neural são o padrão de propagação do sinal, o padrão de manutenção da sua topologia e a conectividade da rede.

Para efeito deste trabalho, a arquitetura representa relação direta com o algoritmo utilizado para treinar a rede, enquanto que a topologia está relacionada à quantidade de neurônios, camadas, entre outros parâmetros.

Os neurônios que compõem uma determinada arquitetura apresentam conexões que fazem com que o sinal de processamento se propague ao longo da rede. Os neurônios podem estar conectados por ligações ascendentes ou descendentes. As conexões ascendentes ligam o neurônio em operação à unidade de processamento posterior. Já as conexões descendentes fazem a ligação do neurônio em operação com os neurônios da etapa anterior de propagação, que podem ser exemplificadas pela retroação do erro obtido ao se comparar o valor da saída desejada com o valor da saída obtido. O exemplo descrito representa uma das fases integradas ao algoritmo Backpropagation, desenvolvido e publicado por Rumelhart, Hinton e Williams em seu famoso trabalho publicado em 1986, denominado Learning representations by backpropagation errors.

Existem diversas arquiteturas de redes neurais. De maneira freqüente, surgem novas arquiteturas e arquiteturas já difundidas são reinventadas sob uma diferente perspectiva. $\mathrm{O}$ trabalho utilizará uma arquitetura específica de rede neural - os mapas auto-organizáveis de Kohonen - como será explora mais adiante. 


\subsubsection{Formas de aprendizagem}

O aprendizado de uma rede neural artificial consiste em um complexo processo no qual os parâmetros livres da rede se ajustam de acordo com as condições do ambiente e dos dados de variáveis que alimentam o modelo. O tipo de aprendizagem varia de acordo com a maneira pela qual os parâmetros são alterados.

Existem dois tipos básicos de treinamento para redes neurais artificiais. Um deles é representado pelo aprendizado supervisionado, no qual existe uma relação conhecida entre pares de estímulos. O outro método denominado não-supervisionado tem como característica a aprendizagem autônoma. O treinamento não-supervisionado é obtido por meio do ajuste da rede até uma resposta estável, para um determinado padrão de entrada. Além dos métodos já citados, existe o aprendizado por reforço, o qual pode ser classificado com uma variação do método supervisionado.

Os mecanismos de aprendizagem se baseiam em algoritmos. Estes algoritmos são desenvolvidos com a inspiração no funcionamento de sistemas vivos ou sistemas físicos em geral, como já citado quando foi feita a analogia entre o neurônio biológico e o computacional.

\subsubsection{Aprendizagem supervisionada}

$\mathrm{Na}$ aprendizagem supervisionada, a rede funciona como um sistema de entrada e saída (input-output). Ao receber uma entrada com vetor $x^{\mu}$ a rede emite um vetor $y^{\mu}$. A simbologia $\mu$, em x, representa o número do padrão de entrada. Já em y, $\mu$ consiste no número do padrão de saída associada ao padrão de entrada $x$.

A aprendizagem de tal sistema funciona mediante a alimentação da rede neural com uma seqüência suficientemente representativa de exemplos $x^{\mu}$ como entradas, e saídas desejadas $y^{\mu}$. Para cada entrada, existe uma saída desejada $y^{\mu}$. O sistema compara a saída real, obtida mediante o processamento do dado de entrada, com a saída desejada, obtendo assim o parâmetro de ajuste dos pesos sinápticos.

Para uma melhor distinção, utiliza-se a notação $\left(y^{\mu}\right)^{\prime}$ para a saída obtida e $y^{\mu}$ para a saída desejada. Assim, $\left(y^{\mu}\right)^{\prime}$ pode ser tida como uma estimativa de $y^{\mu}$. Em alguns casos, os dados $\left(x^{\mu}, y^{\mu}\right)$ usados no treinamento de uma rede podem ser representados por uma função 
$y^{\mu}=f\left(x^{\mu}\right)+n i$, sendo $n i$ um vetor ruído aleatório, agente compensador de distorções nos resultados.

\subsubsection{Aprendizagem auto-organizável (não-supervisionada)}

$\mathrm{Na}$ aprendizagem não-supervisionada, a rede se modifica de acordo com as resposta referentes às entradas $x^{\mu}$, sem considerar nenhum valor de saída $y^{\mu}$. Embora pareça arbitrária e sem objetivo, esta categoria de treinamento é deveras importante e bastante utilizada. Aplicações relevantes podem ser observadas em aplicações para agrupamentos de padrões, ou ainda em restauração de imagens baseadas em padrões de referência previamente treinados.

Neste tipo de treinamento, não se dispõe de uma saída desejada para ser associada a cada estímulo de entrada. Segundo Haykin (2001), redes auto-organizáveis, utilizadas neste estudo, utilizam este tipo de aprendizado.

Durante o aprendizado não-supervisionado, diversos estímulos de entrada são apresentados à rede, que os organiza por associação. Ao ser apresentado à rede, o padrão de entrada recebe a orientação de qual classe este pertence, com base em suas características dispostas. Caso a rede não seja capaz de associar o padrão de entrada a nenhuma classe existente, uma nove será gerada para então ocorrer a sua classificação, o que torna este tipo de aprendizado aplicável em sistemas classificadores (DE AZEVEDO et al., 2000).

Como este trabalho utiliza uma rede neural concebida a partir mapas autoorganizáveis, serão enfatizadas, no tópico seguinte, será explorado o conceito de autoorganização.

\subsubsection{Regras de Aprendizagem}

As regras de aprendizagem difundidas na literatura são de caráter generalizado e algumas das mais conhecidas são provenientes da famosa regra de Hebb (1949). Muitos pesquisadores focam a modelagem de aprendizado biológico como seu objetivo principal, enquanto outros experimentam maneiras particulares de simular a maneira pela qual natureza processa o aprendizado. 
Grande parte das redes neurais artificiais propostas utilizam as seguintes regras: Regra de Hebb (1949), Regra Delta (WIDROW, 1960), Regra ou Modelo de aprendizagem de Kohonen (1982), Regra Retro Propagação do Erro (RUMELHART et al., 1986), Regra de Aprendizagem por Reforço (KLOPF, 1988), Regra de Aprendizagem por CooperaçãoCompetição (GROSSBERG, 1976; KOHONEN, 1982).

\subsubsection{Auto-Organização}

Diversas arquiteturas de redes neurais se baseiam na auto-organização para solucionar uma ampla gama de problemas. Como exemplos, existem a arquitetura denominada Mapa Auto-Organizável de Kohonen (KOHONEN, 1982, 1990, 1997), o aprendizado competitivo proposto por Rumelhart e Zipser (1985), as redes ART (Arquiteture Ressonancy Theory) proposta por Carpenter e Grossberg (1987), o modelo de Willshaw e Von Der Malsburg (1976) e o modelo de Linsker do sistema visual dos mamíferos (LINSKER, 1986).

Dentre uma vasta gama de possíveis aplicações dos princípios da auto-organização, as mais difundidas são voltadas para a compressão de dados, extração de características, préprocessamento para uma rede neural supervisionada, reconhecimento de padrões, entre outras.

Matematicamente, têm-se a auto-organização definida por:

$I^{\prime}: R^{n} \rightarrow R^{m}$ na qual I' representa o conjunto de funções de ativação

$\left(X^{P}, O^{p}\right)$ como conjunto de exemplos $\left(X^{p} \rightarrow\right.$ entradas; $O^{p} \rightarrow$ saídas $)$

$O^{p}=F\left(X^{p}\right)$ havendo apenas $X^{p} \rightarrow$ utiliza-se a auto-organização

Kohonen (1988) afirma que a auto-organização tem os seguintes princípios:

- Modificações nos pesos sinápticos tendem a se estender para as sinapses bem sucedidas que conectam o neurônio vencedor;

- A limitação de recursos leva à competição entre sinapses e, com isso, à seleção das sinapses que crescem mais vigorosamente às custas das outras;

- As modificações em pesos sinápticos tendem a cooperar com outras sinapses, formando vizinhança, apesar da competição global; 
- Ordem e estrutura nos padrões de informação representam informação redundante, adquirida pela rede neural na forma de conhecimento, que é um pré-requisito necessário para a aprendizagem auto-organizada.

Segundo Debrun et al. (1996), processos auto-organizados têm sido estudados nas mais diversas áreas. Na maioria dos casos, o conceito de auto-organização está associado ao incremento do fator organização (ordem) de um sistema, sem que o princípio organizador seja extrínseco ao sistema ou um elemento privilegiado dentro dele.

Por sua vez, Costa (1999) aponta como características básicas de processos autoorganizáveis as seguintes:

- Processos auto-organizados são processos coletivos, onde unidades que fazem parte deste coletivo competem por recursos limitados. Devido à chance de sucessos semelhantes, têm-se a inexistência de hierarquias ou de elementos privilegiados;

- O processo é parcialmente autônomo em relação às suas condições iniciais e se desenvolve por meio de um trabalho de si sobre si;

- A forma final não é resultante passiva do processo. Esta possui uma identidade, entretanto, não-determinística;

- Flutuações nos estados dos elementos podem gerar uma força assimétrica que leve os elementos a um estado maior de organização.

A definição conceitual de auto-organização aplicada a redes neurais artificiais está diretamente ligada ao aprendizado não-supervisionado que infere nas arquiteturas cabíveis. Quando comparado ao treinamento supervisionado, que ocorre a partir de conjuntos rotulados de padrões, nos quais o rótulo define a categoria do padrão que está sendo inserido no sistema, a única informação disposta por sistemas de aprendizagem não-supervisionada (autoorganizáveis) são os próprios padrões, sem rótulos. Assim, as relações entre os padrões devem ser determinadas automaticamente.

Entretanto, é importante diferenciar os objetivos em ambos os casos - aprendizagem supervisionada e não-supervisionada. Em treinamentos supervisionados, o objetivo é maximizar a generalização do sistema na fase de execução em relação aos novos padrões que 
serão alimentados na fase de teste da rede, fase seguinte ao treinamento. Já treinamentos nãosupervisionados têm o objetivo de buscar a estrutura desconhecida do conjunto de padrões. Ao invés de ajustar os parâmetros com o objetivo de minimizar o erro computado entre as saídas obtidas e as saídas desejadas como ocorrem em treinamentos supervisionados, procurase relações implícitas de semelhanças e diferenças a partir da competição entre as unidades de processamento (COSTA, 1999).

\subsection{Mapas Auto-Organizáveis de Kohonen}

Esta dissertação optou por utilizar mapas auto-organizáveis para solucionar o problema de pesquisa apresentado. Sabe-se que as arquiteturas que usufruem de treinamento não-supervisionado consideram de forma mais apropriada à necessidade de se ajustar a complexidade da rede neural em função da natureza do problema abordado, o que já não se aplica com o mesmo ênfase nas redes que atuam sob a perspectiva do treinamento supervisionado.

Os mapas auto-organizáveis de Kohonen contêm duas camadas. A primeira camada, denominada camada de entrada, é responsável pela recepção dos padrões. A segunda camada, denominada de camada de Kohonen, possui o papel de processar os dados de entrada.

O número de neurônios na primeira camada deve ser igual ou superior à quantidade de categorias dos padrões de entrada. No caso desta pesquisa, existem seis categorias, já citadas no capítulo anterior - Prêmios Ganhos, Rentabilidade do Patrimônio Líquido Médio, Margem Operacional, Endividamento, Sinistralidade e Independência Financeira. O número de nós da camada de Kohonen deve ser igual ou superior ao número de classes a serem aprendidas.

Assim, os padrões de entrada $x^{\mu} \in R^{N}$, contendo um dos $n$ sinais de entrada $\left(x_{1}^{\mu}, x_{2}^{\mu}, \ldots, x_{n}^{\mu}\right)$, podem ser classificados em $\mathrm{k}$ classes. Então, deve-se estruturar um mapa de Kohonen composto por uma camada de entrada e camada de Kohonen contendo respectivamente $n$ e $k$ neurônios.

Haykin (2001) define o conceito de 'mapa auto-organizável' como sendo a capacidade de formação de um mapa topográfico dos padrões de entrada, no qual as localizações espaciais dos neurônios são indicativas das características estatísticas intrínsecas contidas nos padrões de entradas. 
De um modo geral, mapas auto-organizáveis buscam transformar, adaptativamente e de maneira topologicamente ordenada, um padrão de sinal incidente de dimensão arbitrária em um mapa discreto (HAYKIN, 2001). Um dos principais atributos do mapa autoorganizável de Kohonen consiste em, por meio de um algoritmo não-supervisionado, aproximar a densidade de probabilidade dos dados de entrada simultaneamente à redução da dimensionalidade, com o objetivo de preservar ao máximo as relações topológicas entre os dados (KOHONEN, 1982).

Mapas auto-organizáveis tiveram relevantes aplicações no campo da biologia e da neurofisiologia, por meio de trabalhos como o estudo de Zeki (1993), que criou mapas para processar a orientação de segmentos de reta e mapas de cores para a visão e o estudo de Hubel e Wiesel (1962), que utilizou micro-eletrodos no córtex visual de gatos.

Como aplicação em ramos da economia e finanças, pode-se citar o trabalho de Bialoskorski Neto et al. (2006), que utilizou uma SOM de Kohonen para avaliar, sob uma perspectiva sócio-econômica, um grupos de unidades cooperativas.

\subsubsection{Aprendizado Competitivo}

O aprendizado competitivo tem como objetivo fazer com que neurônios se especializem em estímulos apresentados de forma não-supervisionada. Assim, nenhuma informação sobre a classe do estímulo apresentado é usada no processo de ajustes dos pesos sinápticos. Todos os neurônios recebem o mesmo conjunto de entradas e assim competem com todos os outros neurônios ao seu redor, por meio de conexões laterais. As conexões laterais podem ser inibitórias (negativas) ou positivas, em casos de auto-alimentação.

O princípio básico do aprendizado competitivo consiste na quantização vetorial, que aproxima a função densidade de probabilidade do sinal de entrada, por meio de um conjunto finito de vetores de referência. A função densidade de probabilidade é utilizada para apresentar a distribuição de probabilidade aplicada a variáveis aleatórias contínuas.

No treinamento competitivo, os neurônios competem entre si para serem ativados, e por conseqüência, apenas um neurônio de saída, ou um neurônio por grupo, está ativado em um determinado instante de tempo. Tal neurônio é denominado neurônio vencedor.

Segundo Rumelhart e Zipser (1985), existem três regras básicas de aprendizado competitivo. São elas: 
- O conjunto de neurônios dispõe da mesma função de ativação e se diferencia inicialmente apenas pela distribuição aleatória dos pesos sinápticos, que farão com que os neurônios reajam de maneira diferente para um dado conjunto de padrões;

- Os vetores de pesos que conectam neurônios entre as camadas de entrada e a de saída são limitados;

- Deve haver um mecanismo que permita aos neurônios competir pelo direito de responder a um dado subconjunto de entradas. Ao final do processo de competição, apenas um neurônios estará ativo (regra do winner-takes-all).

A regra do winner takes all, ou seja, "vencedor leva tudo", funciona por meio do uso de conexões laterais inibitórias entre os neurônios, idéia inicialmente proposta por Rosenblatt (1958).

Entretanto, as regras citadas não são únicas e absolutas e as condições são maleáveis e podem ser estendidas ou ainda desconsideradas. Em certos casos, existem condições nas quais se podem considerar mais de um neurônio como vencedor para um determinado padrão ou ainda dispensar a normalização dos pesos citada nas regras acima.

A Figura 8 servirá de ilustração para uma melhor compreensão do aprendizado competitivo. A partir da introdução de um vetor $\mathbf{x}$ normalizado $((\|x\|=1)$ à camada de entrada da rede, cada neurônio $O_{i}, i=1,2, \ldots, k$, da camada de saída irá adotar um valor de ativação. $\mathrm{O}$ neurônio vencedor $c$ será o neurônio que apresenta a ativação máxima, ou seja, a maior similaridade com o padrão apresentado. Segundo Kohonen (1993), as conexões laterais podem ser utilizadas em um processo dinâmico de competição, para assim inibirem os outros neurônios. Ao final do processo, apenas um neurônio, $c$, permanecerá ativo. Uma das diversas formas de se realizar tal processo seria saturar o neurônio vencedor em 1, por exemplo, enquanto todas as outras unidades de processamento são desativadas por aquele padrão. 


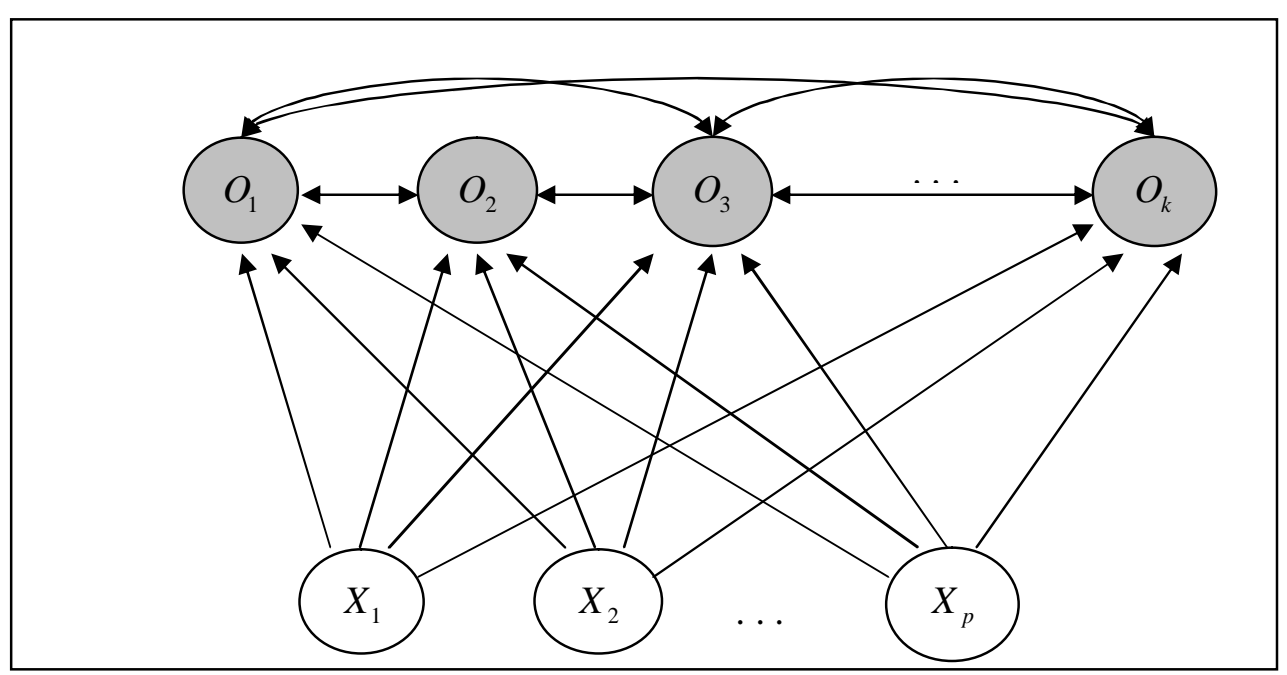

Figura 8 - Rede neural competitiva simples

No aprendizado competitivo, o ajuste da média dos vetores é restrito ao neurônio vencedor $c$, a cada apresentação de um padrão. O neurônio vencedor é, portanto, a unidade de processamento que dispõe do conjunto de pesos mais semelhantes ao padrão apresentado. Segundo um critério de distância entre x e $m_{i}, d\left(x, m_{i}\right)$, o vencedor $c$ é identificado pela expressão:

$d\left(x, m_{c}\right)=\min _{i}\left\{d\left(x, m_{i}\right)\right\}$

A adaptação dos pesos sinápticos aplica-se apenas sobre o neurônio vencedor $c$, por meio da expressão a seguir:

$\Delta m_{c}(t+1)=\alpha(t) \cdot\left[x(t)-m_{c}(t)\right]$

Para todos os neurônios restantes, $i=1, \ldots, k, i \neq c, \Delta m_{i}(t+1)=0$. A taxa de aprendizagem $\alpha(t)$ pode ser uma função decrescente e monotônica, limitada em $0<\alpha(t)<1$. Essa regra reproduz o efeito de deslocamento dos pesos do neurônio vencedor na direção do padrão x, ilustrado pela Figura 9. 


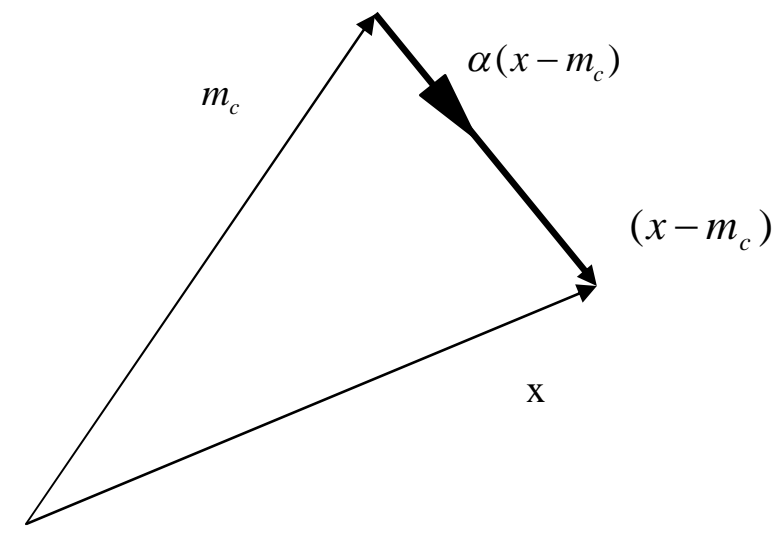

Figura 9 - Atualização dos pesos em uma rede neural competitiva

\subsubsection{Estrutura Básica de uma rede SOM}

Mapas auto-organizáveis funcionam por meio de um algoritmo relativamente simples, e são tidos como uma ferramenta aplicada a diversos softwares para a visualização de dados.

Um mapa auto-organizável possui duas camadas de neurônios, sendo elas a camada de entrada e a camada de saída. As entradas da rede são vetores dispostos no espaço, ndimensional. Cada neurônio $i$ da rede dispõe também de um vetor, também disposto no espaço, e de composição $w_{j}=\left[w_{j 1}, w_{j 2}, \ldots, x_{j m}\right]^{T}$. Os neurônios da camada de saída se conectam aos neurônios adjacentes mediante relações de vizinhança. Em uma situação bidimensional, por exemplo, pode-se ilustrar com a Figura 10 abaixo uma rede SOM de tamanho $6 \times 5$, e dimensionalidade de entrada $\mathrm{p}=3$.

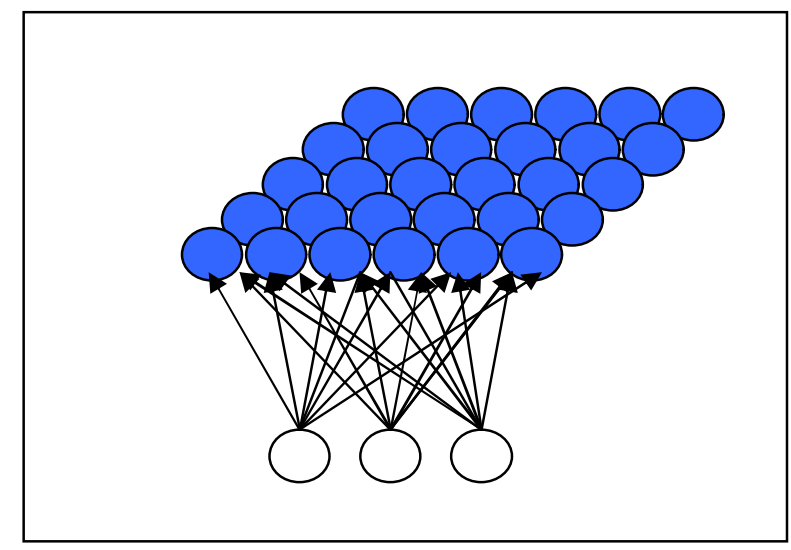

Figura 10 - Rede SOM de tamanho 6x5, e dimensionalidade de entrada $\mathrm{p}=3$. 
Regularmente, os dados de aplicações em uma rede SOM são multidimensionais. Tal fato dificulta a compreensão das relações que os dados de entrada dispõem entre si. O mapa auto-organizável implementa uma projeção não-linear de um espaço de dados de atributos, geralmente superior a um espaço bidimensional, em um conjunto discreto de neurônios, normalmente dispostos na forma de um ou mais vetores - matriz. Segundo Kohonen (1993), relações estatísticas complexas e não-lineares entre os dados são transformadas em relações geométricas simples, baseadas em medidas de dimensão. Por sua vez, o mapa autoorganizável é obtido matematicamente por regressão recursiva e não-paramétrica (KOHONEN, 1997).

Haykin (2001) cita que o principal objetivo do mapa auto-organizável é transformar um padrão de sinal incidente de dimensão arbitrária em um mapa discreto uni- ou bidimensional e, assim, realizar esta transformação adaptativa de uma maneira topologicamente ordenada. Segundo Leung et al. (2004), os dois objetivos principais de mapas auto-organizáveis são reduzir a dimensionalidade dos dados, na medida em que simultaneamente tenta preservar as relações métricas e topológicas do espaço de entrada. Embora alguns autores contestem estes dois objetivos, considerando-os antagônicos, esta pesquisa os adotara como premissas.

A dimensionalidade do mapa é obtida a partir das relações de vizinhança entre os neurônios. Outra característica que se pode extrair de uma rede SOM treinada é a aproximação da função densidade de probabilidade dos dados.

Como tal arquitetura preserva as relações topológicas, informações semelhantes são mapeadas em neurônios próximos, com possibilidade de serem mapeadas nos mesmos neurônios, o que caracteriza a quantização ou agrupamento do espaço de entrada. Já as relações de vizinhança entre os neurônios, estabelecidas ao longo do processo de treinamento, tornarão possível a união posterior dos neurônios que respondem a estímulos semelhantes em conjuntos de neurônios. A partir de tal julgamento, inicia-se a formação de clusters, que é o processo proposto para se atingir o objetivo desta pesquisa.

A Figura 11 representa um diagrama de uma grade de neurônios regularmente adotada como mapa discreto auto-organizável. Todos os neurônios da grade estão conectados com todos os nós da camada de entrada. Pode-se observar que a grade representa uma estrutura 
alimentada de forma adiante - feedfoward, com uma única camada computacional de neurônios arranjados em linhas e colunas.

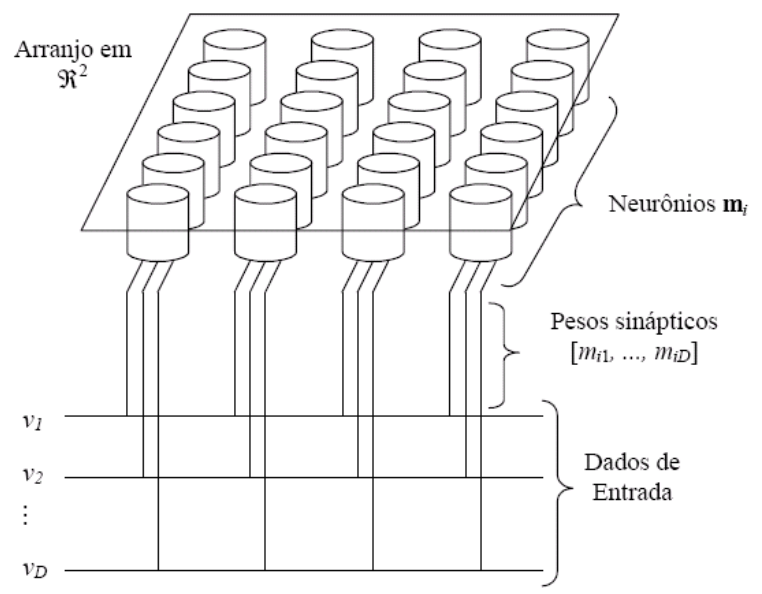

Figura 11 - Grade de neurônios Fonte: Haykin (2001)

Cada padrão de entrada que é introduzido à rede está relacionado a uma região específica, que possui um ponto de atividade contra a indução ao repouso. A localização e a natureza deste foco dependem da natureza do padrão de entrada. Por isso, via de regra todos os neurônios devem ser expostos a um número suficiente dados referente a um padrão de entrada, para garantir que o processo de auto-organização se torne devidamente treinado.

Um mapa auto-organizável é gerado por meio de um algoritmo, que se inicia seu funcionamento com a atribuição de pesos sinápticos da grade. A literatura, de uma forma geral, afirma que uma maneira de se iniciar tal processo consiste em atribuir valores pequenos e obtidos de forma aleatória, para que assim nenhum viés seja imposto ao mapa. Após iniciar a grade, se iniciam três processos básicos e essenciais para a formação do mapa autoorganizável.

O primeiro processo denomina-se competição. Nesse estágio, os neurônios da rede calculam os valores de uma determinada função discriminante para cada padrão de entrada. Essa função discriminante fornece a base para a competição entre os neurônios, pois a unidade de processamento que obtiver o maior valor resultante da função será denominada como o vencedor.

Supõe-se que $m$ representa a dimensão do espaço de entrada de dados e que um padrão de entrada em forma de vetor selecionado de modo aleatório seja representado por 
$x=\left[x_{z}, x_{2}, \ldots, x_{m}\right]^{T}$. O vetor peso sináptico de cada neurônio tem a mesma dimensão que o espaço de entrada. Adota-se também que o vetor de pesos de um determinado neurônio seja representado por $w_{j}=\left[w_{j 1}, w_{j 2}, \ldots, x_{j m}\right]^{T}$, e $j=1.2 \ldots l$, com 1 sendo o número total de neurônios da grade.

Vale ressaltar que cada nó da camada de entrada possui um peso fixo $w_{e}=1$, para não alterar os valores de cada padrão recebido. Entretanto, cada neurônio $j$ da camada de Kohonen tem $i$ pesos $w_{i j}$ associado a este.

Com o objetivo de encontrar a melhor interação entre vetor de entrada $\mathbf{x}$ e o vetor de pesos sinápticos $\mathbf{w}$, devem-se comparar os produtos internos $w_{j}^{T} x$, para $j=1.2 \ldots . l \mathrm{e}$ selecionar o que obtiver o maior resultado. Ao se selecionar o neurônio com o maior produto interno $w_{j}^{T} x$, definir-se-á a localização na qual a vizinhança topológica dos neurônios excitados deve ser centrada. Haykin (2001) ressalva que o critério para achar tal resultado é recorrente ao cálculo da minimização da distância euclidiana entre os vetores $\mathbf{x}$ e w. Sendo o índice $i(\mathrm{x})$ para identificar o neurônio que melhor se combina com o vetor de entrada $\mathbf{x}$, determina-se i(x) por meio da Expressão 18.

$$
i(x)=\arg \min \left\|x-w_{j}\right\|, j=1,2, \ldots, l
$$

Assim, define-se o processo competitivo que ocorre entre os neurônios componentes de uma rede SOM. De acordo com a Expressão 16, $i(\mathrm{x})$ identifica a identidade $i$ do neurônio vencedor.

O segundo processo essencial na formação de um SOM denomina-se cooperação. Nessa etapa, o neurônio vencedor define a localização espacial de uma vizinhança topológica de neurônios excitados, o que serve de arcabouço para a cooperação das unidades processadoras vizinhas. Kohonen (1982) afirma que um neurônio ao disparar impulsos em estado de ativação tende a excitar de uma maneira mais intensa aqueles que estão ao seu redor que àqueles que se encontram mais distantes da unidade ativada.

Assim, a vizinhança topológica ao redor do neurônio vencedor $i$ diminui gradativamente com o aumento da distância entre o neurônio vencedor e os demais (LO et al., 1991, 1993; RITTER et al., 1992). Sendo $h_{j, i}$ a vizinhança topológica concentrada no neurônio vencedor $i$, nela deve estar contido um conjunto de neurônios excitados e um 
neurônio qualquer dessa vizinhança é representado por $j$. Não obstante, $d_{i j}$ representa a distância lateral entre o neurônio vencedor $i$ e o neurônio excitado $j$.

Para que a vizinhança topológica $h_{j, i}$ seja uma função da distância $d_{i j}$, duas premissas devem ser consideradas.

- Simetria na região $h_{j, i}$ em relação ao ponto máximo, obtido por $d_{i j}=0$. Obviamente, a distância entre o neurônio vencedor, que possui o valor máximo, e ele mesmo será sempre zero;

- $h_{j, i}$ possui amplitude decrescente com o aumento de $d_{i j}$, tendendo a zero para $d_{i j} \rightarrow \infty$. Sem essa premissa, não há convergência.

Haykin (2001) propõe a definição de $h_{j, i}$ por meio da função gaussiana representada pela Expressão 19 a seguir.

$h_{j, i(x)}=\exp \left(-\frac{d_{j, i}^{2}}{2 \sigma^{2}}\right)$

O parâmetro $\sigma$ representa a largura efetiva da vizinhança topológica, e mede o grau de participação dos neurônios não-vencedores no processo de aprendizagem. Assim, a influência de cada neurônio vencedor é mais ampla no centro de sua região e se dissipa ao longo do aumento da distância. A Figura 12 traça a curva referente á Expressão 17. 


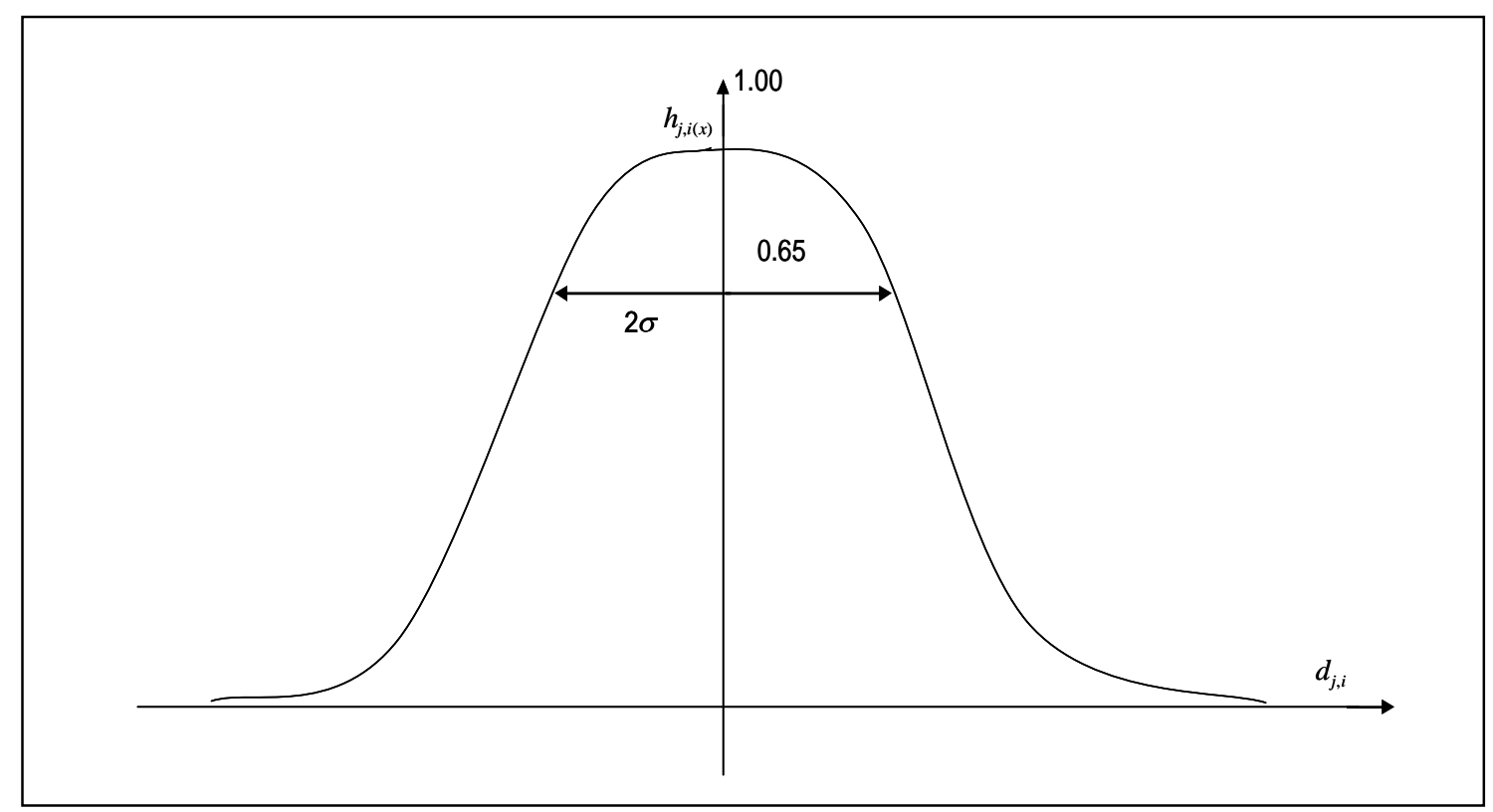

Figura 12 - Gráfico de uma função gaussiana

Buscando manter a cooperação entre unidades de processamento vizinhas, faz-se necessário que a vizinhança $h_{j, i}$ dependa da distância lateral $d_{j, i}$ entre o neurônio vencedor $i$ e o neurônio excitado $j$ no espaço de saída, no lugar de ser dependente de alguma medida de distância no espaço de entrada. É necessário que a função tenha processado o dado de entrada para ocorrer a comparação.

O último estágio necessário para a formação do mapa auto-organizável é o da adaptação sináptica, que permite aos neurônios excitados aumentarem seus valores individuais da função discriminante em relação ao padrão de entrada de ajustes nos pesos sinápticos. Para que um mapa seja auto-organizável, é preciso que o vetor de pesos sinápticos $w_{j}$ do neurônio $j$ da grade se ajuste em relação ao vetor de entrada $\mathbf{x}$. Portanto, tem-se $w_{j}$ como o vetor de peso sináptico do neurônio $j$ e $g(y)$ como uma função escalar positiva da resposta $y_{j}$. Como premissa para esta etapa, deve-se adotar para a função $g(y)$ é que seu termo constante seja zero para se adotar:

$g(y)=0$, para $y_{j}=0$

A partir de tal pressuposto, o vetor de peso sináptico do neurônio $j$ é ajustado conforme a Expressão 21 abaixo:

$\Delta w_{j}=\eta y_{j} x-g\left(y_{j}\right) w_{j}$ 
Na expressão acima, o termo $\eta$ representa a taxa de aprendizagem do algoritmo em uso. O termo $\eta y_{j} x$ representa o termo denominado hebbiano - proveniente das teorias propostas por Hebb (1949). O segundo termo, $g\left(y_{j}\right) w_{j}$ consiste no termo de esquecimento, que modifica o que foi proposto originalmente o algoritmo proposto por Hebb.

Acompanhando o desenvolvimento proposto por Haykin (2001), procura-se satisfazer a expressão 22 por meio da escolha de uma função linear para $g(y)$ como se segue:

$$
g\left(y_{j}\right)=\eta y_{j}
$$

A Expressão 22 pode ser simplificada se:

$$
y_{j}=h_{j, i(x)}
$$

Aplicando as Equações 22 e 23 na Expressão 20, obtém-se:

$$
\Delta w_{j}=\eta h_{j, i(x)}\left(x-w_{j}\right)
$$

Com o uso de todas as equações acima e considerando a defasagem no tempo discreto, tendo-se um vetor de peso sináptico $w_{j}(n)$, referente ao neurônio $j$ no instante de tempo $n$, o vetor de peso atualizado $w_{j}(n+1)$ no tempo $(n+1)$ é definido por (KOHONEN, 1982; RITTER et al., 1992, KOHONEN, 1997):

$$
w_{j}(n+1)=w_{j}(n)+\eta(n) h_{j, i(x)}(n)\left(x-w_{j}(n)\right)
$$

Assim, torna-se possível modificar o vetor peso sináptico $w_{i}$ do neurônio vencedor $i$ em direção ao vetor de entrada $\mathbf{x}$. Conforme são apresentados os padrões de entrada para treinamento, os vetores de pesos sinápticos tendem a seguir a distribuição dos vetores de entrada, conseqüência da atualização dos pesos dos neurônios vizinhos. Assim, neurônios adjacentes tendem a ter pesos sinápticos semelhantes. 


\section{CAPÍTULO 4 - MÉTODO DE PESQUISA E PLANEJAMENTO DO EXPERIMENTO}

O método e as técnicas a serem empregados nesta pesquisa científica estão adequados com a delimitação e a natureza do problema proposto, motivada pela necessidade de resolver questões concretas e objetivando investigar, comprovar ou ainda rejeitar possibilidades e conclusões inapropriadas.

A abordagem quantitativa denota quantificar dados, nas formas de coleta de informações, utilizando recursos e técnicas estatísticas para garantir a precisão dos resultados, evitando distorções de análise e interpretações (OLIVEIRA, 1999).

O presente trabalho científico também enfoca a pesquisa descritiva para o estabelecimento de seu marco teórico e conceitual, com base em seu objetivo primordial: a descrição das características de determinado fenômeno, ou a verificação da relação entre variáveis, empregando técnicas voltadas para a matemática e estatística (GIL, 1991).

Assim, a metodologia utilizada é classificada como pesquisa descritiva, pois segundo Rudio (1978), está interessada em descobrir e observar fenômenos, procurando descrevê-los, classificá-los e interpretá-lo. Este autor também afirma que a pesquisa descritiva deseja conhecer a natureza do fenômeno estudado, sua composição, processos que o constituem ou que nele se realizam. Tais características se aplicam adequadamente nesta situação.

No entanto, a pesquisa realizada também possui caráter exploratório, pois fornecerá dados para identificação dos principais vantagens que podem ser obtidas com o incremento eficiente de processos decisórios, ao se aplicar as técnicas propostas - DEA e RNA à uma determinada população de empresas.

Apoiando-se em redes neurais artificiais e técnica de análise por envoltória de dados, o trabalho pretende obter resultados que venham contribuir para a comunidade científica e para todos os stakeholders relacionados com o setor de seguros privados. Envolve duas das onze subáreas da Engenharia de Produção: a) Engenharia Econômica - visto que a pesquisa procura incrementar a credibilidade de rankings de empresas que compõem um específico setor da 
economia com base em dados econômico-financeiros, e ; b) Pesquisa Operacional, por utilizar as técnicas propostas.

O desenvolvimento do trabalho ocorreu ao longo de quatro etapas. A primeira etapa consistiu em uma revisão bibliográfica, mediante a consulta em livros e periódicos, ambos nacionais e internacionais. Para a realização desta etapa, a revisão da literatura se balizou nas colocações de Cervo e Bervian (1983): evitar uma possível duplicidade de pesquisa e a repetição de falhas ocorridas em pesquisas anteriores; determinar a contribuição da pesquisa para seu devido campo de conhecimento; e obter fundamentação teórica para desenvolver o restante do trabalho.

A segunda etapa, denominada de estudo exploratório, corroborou as técnicas a serem utilizadas por esta pesquisa, assim como o estabelecimento de um banco de dados para as aplicações das técnicas propostas. Procurou-se também estabelecer as possíveis contribuições desta pesquisa para com a literatura pertinente. A fase seguinte, delimitada por um estudo descritivo, objetivou estudar e descrever as características e propriedades existentes do setor sob estudo e também das técnicas a serem utilizadas - redes neurais artificiais e análise por envoltória de dados (CERVO; BERVIAN, 1983).

As três primeiras etapas estão dispostas ao longo dos capítulos sobre o setor de seguros e sobre as técnicas a serem utilizadas. Já a quarta e última etapa, que caracteriza-se pela análise dos dados e dos resultados obtidos, encontra-se no capítulo 5, de Resultados Obtidos. Nesta fase todas as informações coletadas nas fases anteriores sobre as técnicas, metodologias e sobre o setor de seguros foram utilizadas para a elaboração dos rankings propostos pelo objetivo deste trabalho.

\subsection{Dados da pesquisa}

Segundo Sampieri et al. (1991), após a seleção do tipo de pesquisa a ser adotada, deve-se proceder a coleta de dados pertinentes às variáveis envolvidas na investigação e de informações sobre as técnicas e ferramentas a serem utilizadas.

Os dados utilizados na pesquisa foram retirados de uma base de dados que se encontra no site da Fundação Getúlio Vargas (www.fgv.br). Nesta base de dados, encontram-se informações contábeis, financeiros e operacionais das 100 maiores seguradoras do país. O ranking do setor de seguros realizado elaborado anualmente, e que servirá de parâmetro comparativo para esta dissertação, é estabelecido com base em indicadores econômico- 
financeiros das empresas que compõem o setor. O estudo que esta dissertação adota como parâmetro selecionou as empresas que obtiveram o melhor resultado de desempenho econômico-financeiro no exercício de 2006.

\subsubsection{O ranking original}

A seleção de empresas utilizadas pela base de dados considerada lista as unidades de negócio que se destacaram no mercado sob estudo, baseada no desempenho das componentes em relação a seis indicadores de origem financeiro-contábil. A Fundação Getúlio Vargas publica anualmente uma classificação das empresas componente do setor de seguros privados. Em sumas gerais, o trabalho em questão atribui pesos a cada indicador, e assim - por meio de uma multiplicação direta entre pesos versus desempenho - estabelece-se a ordenação. Este fato permite ressaltar a seguinte questão: O quão subjetiva pode consistir a análise da revista? Assim, a colocação final das empresas é determinada pela sua classificação em cada indicador ponderada por parâmetros atribuídos pelos autores a cada um dos seis indicadores propostos.

Esta pesquisa visualiza a oportunidade de se reduzir o fator de subjetividade ao elaborar um ranking mediante as técnicas estudadas - redes neurais artificiais e análise por envoltória de dados.

O primeiro indicador considerado pelos pesquisadores foi o montante de Prêmios Ganhos. Tal indicador representa o market share da empresa perante seu segmento de atuação e pode ser estabelecido por meio da Expressão 26 seguinte:

Pr êmios ganhos $=$ Pr êmios Retidos - Variação das Provisões de Pr êmios

Seu julgamento é estabelecido mediante a relação de que quanto mais alto for o seu valor em termos absolutos, melhor para a empresa que o dispõe. O trabalho original atribuiu a este indicador o peso 3,00.

O segundo indicador que fundamenta o ranking original é denominado Rentabilidade do Patrimônio Líquido Médio, adotado em valores relativos (\%). Esse indicador é definido pela mensuração do retorno final dos acionistas em relação ao capital próprio da instituição e seu valor é determinado pela Expressão 27 abaixo:

Re ntabilidade do PL médio $(\%)=\frac{\text { Lucro Líquido }}{\text { Patrimônio Líquido }} \times 100$

A classificação escalar deste indicador é tida pela relação de quanto maior o 
percentual, melhor será a contribuição deste indicador para a classificação final da empresa. A ponderação atribuída à Rentabilidade do Patrimônio Líquido foi de 2,50 pontos.

Na seqüência, o terceiro parâmetro construtor do ranking é a Margem Operacional, que representa a margem operacional de lucro com a atividade seguradora. Esse indicador estabelece a relação entre o montante gerado pela atividade principal da empresa e o montante que ela recolhe por meio do faturamento de prêmios ganhos. A Expressão 28 a seguir determina, em valores percentuais, o valor da Margem Operacional:

$$
M \arg \text { em Operacional }=\frac{\text { Re sultado Operacional de Seguros }}{\text { Pr êmios Ganhos }} \times 100
$$

Assim como os dois primeiros, esse indicador é interpretado como quanto maior o seu valor, maior sua influência para a obtenção de uma melhor colocação no ranking. O peso atribuído para fins de cálculo da média ponderada dos seis indicadores foi estabelecido em 1,00 ponto.

O quarto indicador, atribuído de uma ponderação de 1,00 ponto é denominado Endividamento. Esse índice mede todo o montante que a empresa deve a terceiros em devidas proporções a seu capital próprio, baseado no patrimônio líquido. Seu julgamento refere-se a quão menor o seu valor, melhor para a corporação que o dispõe. A Expressão 29 expõe a sua composição:

$$
\text { Endividamento }=\frac{(P C+P E L P-P T)}{P L}
$$

Na qual:

$\mathrm{PC}=$ Passivo Circulante;

PELP = Passivo Exigível a Longo Prazo;

$\mathrm{PT}=$ Provisões Técnicas; $\mathrm{e}$

PL = Patrimônio Líquido

Miller (2006) ressalta que, referente ao quarto indicador, existe uma relação ótima entre capital próprio e capital de terceiros e que este índice varia para cada corporação, individualmente. Essa relação fundamenta-se no conceito de Custo Médio Ponderado de Capital, que aponta o grau ideal que uma empresa deve possuir com o objetivo de maximizar seus resultados e alavancar capital para outras iniciativas.

O penúltimo indicador consiste na Sinistralidade. Este quantifica a representatividade dos gastos com sinistros e com as principais despesas correntes diante do montante de prêmios ganhos. Adota o caráter de quão menor for o seu valor, maior será o benefício a uma 
boa posição da empresa no ranking. A Expressão 30 demonstra sua formulação:

Sinistralidade $=\frac{\text { Sinistros Re tidos }}{\text { Pr êmios Ganhos }}$

Assim, a Sinistralidade indica o nível de comprometimento dos prêmios com as indenizações a segurados. Este indicador recebeu como ponderação o valor de 1,00 pontos, de acordo com o julgamento dos autores do ranking.

Por último, tem-se o indicador chamado Independência Financeira, que mede a relação entre recursos próprios e o total de recursos da empresa. É obtido pela Expressão 31 a seguir. Quanto maior o quociente de Independência Financeira, melhor colocada estará a empresa. Entretanto, existe um grau ótimo de endividamento, determinado pelo custo médio ponderado de capital (COPELAND et al., 1995).

IndependênciaFinanceira $=\frac{\text { Patrimônio Líquido }}{\text { Ativo Total }}$

Os dados utilizados em ambas as técnicas foram os mesmos que constam no banco de dados disposto no site da Fundação Getúlio Vargas citado acima. O período selecionado de análise se deve ao exercício de 2006 ser o último ano a ser publicado quando se teve a iniciativa de realizar esta pesquisa, sendo assim o período mais recente até então.

Para a aplicação das duas técnicas, foram consideradas todas as unidades de negócio que constam na publicação original, pois realizam as mesmas atividades com os mesmos propósitos, além de estarem trabalhando dentro das mesmas condições de mercado e de estarem sujeitas às mesmas variáveis.

Seguindo o objetivo de se aplicar a técnica de análise por envoltória de dados e de redes neurais de forma a se verificar como as empresas estão posicionadas em ordem de eficiência em suas atividades, esta pesquisa considera todo o universo de empresas seguradoras no país, uma vez que se tem a intenção de se comparar os rankings gerados por meio das técnicas exploradas com o ranking original. Vale ressaltar o fato de não existir nenhuma empresa do setor com características que a classifique como componente outlier, não se fez necessário a exclusão de nenhuma empresa componente do banco de dados original.

Como ferramenta para viabilizar o uso das técnicas propostas, foram utilizados os softwares Frontier Analyst para a técnica DEA, e o software Matlab para redes neurais. Ambos são sistemas bastante difundidos no meio acadêmico e trabalham com uma considerável gama de dados. 
No entanto, o banco de dados considerado para esta pesquisa e que pode ser visto no Anexo A, se encontrava inicialmente em estado bruto, com dados em diferentes ordens de escala e sem nenhum indício de comportamento adequado à possíveis distribuições estatísticas. No entanto, para que os dados estivessem ajustados de forma correta para serem apresentados ao software Frontier Analyst e que se encaixassem na função de ativação adotada pelo modelo neural, foi necessário que os mesmos passassem por um processo de padronização.

Assim, adotou-se a distribuição de dados dos indicadores considerados e foi realizado o seguinte processo de padronização para cada distribuição (indicador), ao longo das cem DMU's presentes na análise:

$$
x_{\text {padronizado }}=\frac{x-x_{\text {menor }}}{\max \left(x-x_{\text {menor }}\right)}
$$

Após a padronização, obtiveram-se todos os dados dentro do intervalo entre zero e um, e pode-se então iniciar a aplicação por Análise por Envoltória de Dados e Redes Neurais Artificiais.

\subsection{Aplicação da técnica DEA}

Como premissa inicial para a aplicação da técnica DEA, verificou-se a condição estabelecida por Cooper et al (2000) e exposta anteriormente, obtendo-se $100 \geq \max \{3 \times(3+3)\} \therefore 100 \geq 18$. Portanto, a quantidade de variáveis e de DMUs satisfaz tal condição.

Como ponto de partida, a aplicação considerou a possibilidade de utilizar os dois modelos: CCR e BCC. O ranking destas empresas foi analisado por meio da aplicação da técnica DEA, com o intuito de gerar um parâmetro de comparação entre os rankings gerados por esta pesquisa e o ranking oriundo da base de dados. Esta avaliação identificou qual modelo se ao conjunto de dados de modo a obter o melhor resultado possível. Para contemplar todas as possibilidades, foram gerados modelos com os diferentes tipos de retornos - constantes e variáveis, e orientado para os dois objetivos - minimização de inputs ou maximização de outputs.

Com base nestes sistemas, surge o seguinte questionamento: Um determinado modelo - CCR ou BCC, uma vez orientados ora para minimização dos inputs, ora para 
maximização dos outputs, apresenta rankings iguais? Em linha com este questionamento, Almeida, Mariano e Rebeletto (2006) comprovaram que as empresas eficientes são iguais em ambas as orientações, e que as unidades ineficientes são similares nas duas orientações.

Ao longo da aplicação dos modelos propostos por meio da utilização do software Frontier Analyst 3.2, respostas para esses questionamentos foram encontradas e podem ser observadas ao longo desta seção e também na seção que explora os resultados obtidos. Diante das possibilidades de modelos e orientações, e considerando que a fonte de onde foram retirados os dados adotou algumas ponderações para os indicadores elaborados, o método para aplicação da técnica de Análise por Envoltória de dados escolhido contemplou uma comutação de modelos - BCC e CCR, orientações - minimização de inputs ou maximização de outputs, e de presença ou ausência de pesos. A comutação de modelos pode ser observada na figura 13 a seguir:

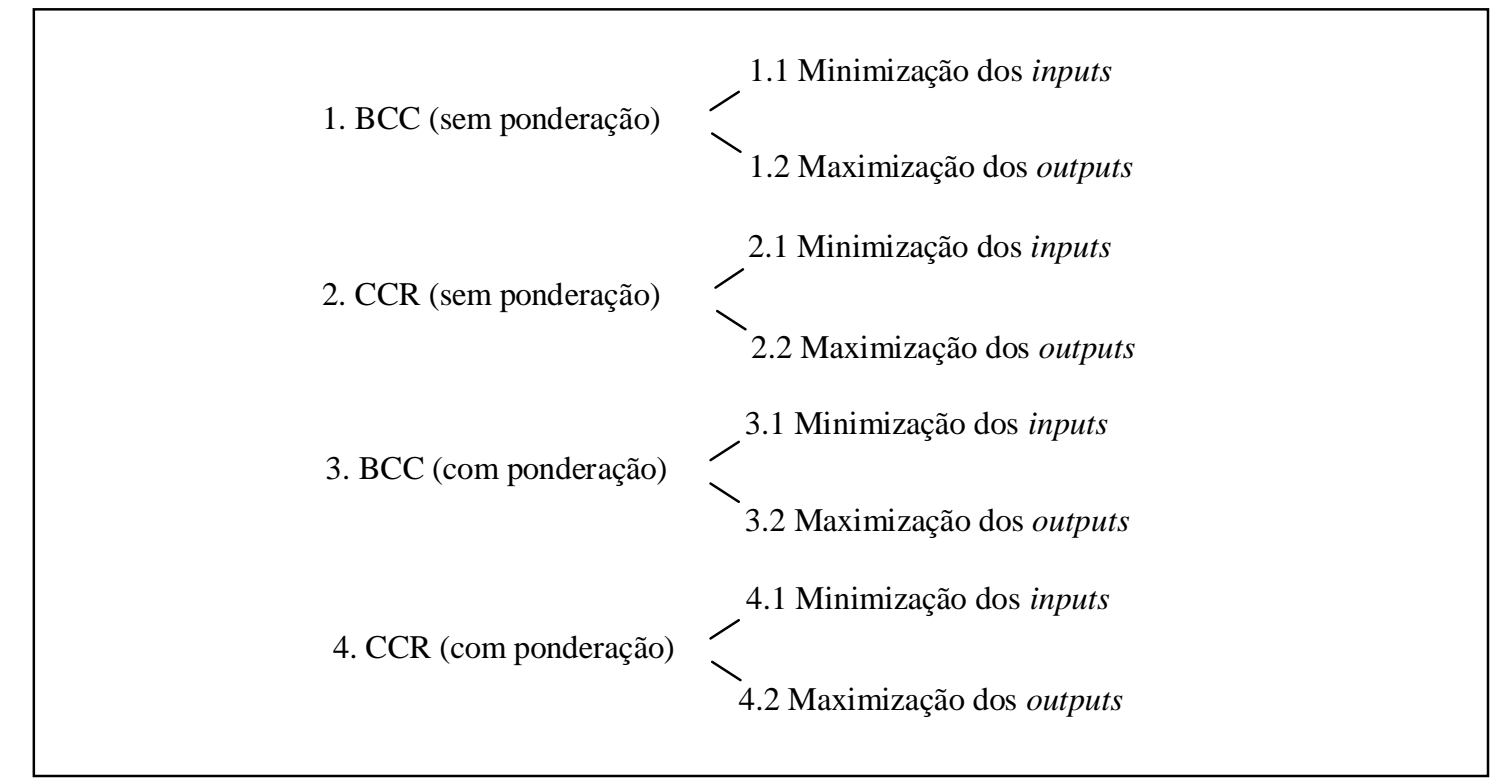

Figura 13 - Modelos DEA considerados na análise

Além das combinações entre tipos de retornos, orientações e presença ou ausência de ponderações, foi adotada inicialmente uma combinação de variáveis com o objetivo de mapear o comportamento do modelo de acordo com a presença ou ausência de algumas variáveis. As combinações de variáveis foram realizadas conforme segue: 


\begin{tabular}{|l|}
\hline \multicolumn{1}{|c|}{ Modelo } \\
\hline Completo \\
\hline Sem Sinistralidade \\
\hline Sem Independência Financeira \\
\hline Sem Endividamento \\
\hline Sem Rentabilidade do patrimônio Líquido \\
\hline Sem Margem Operacional \\
\hline Sem Prêmios Ganhos \\
\hline Sem Endividamento, Margem Operacional e Premios Ganhos \\
\hline Sem Margem Operacional e Premios Ganhos \\
\hline Sem Independência Financeira, Margem Operacional e prêmios Ganhos \\
\hline Sem Endividamento, Independência Financeira e Prêmios Ganhos \\
\hline Sem Endividamento, Independência Financeira e Margem Operacional \\
\hline
\end{tabular}

Quadro 2 - Combinação de variáveis para o ajuste do modelo

Para todos os modelos considerados foram geradas as fronteiras invertidas, baseadas nos dados referentes à fronteira pessimista, com o objetivo de eliminar eventual empate de DMU's eficientes. Segundo Almeida, Mariano e Rebelatto (2007), a fronteira invertida auxilia na seleção da DMU mais eficiente dentre as DMU's consideradas eficientes, elegendo como a unidade mais eficiente aquela que conseguir ter um desempenho mais equilibrado, maximizando a produção de todos os outputs, minimizando a utilização de todos os inputs. $\mathrm{O}$ processo para criação da fronteira invertida se sucedeu da seguinte forma:

1. Os inputs sinistralidade, Independência Financeira e Endividamento foram considerados como outputs, e os outputs Rentabilidade do Patrimônio Líquido, Margem Operacional e Prêmios Ganhos foram tidos como inputs;

2. Todas as combinações de modelos foram geradas;

3. A partir dos modelos gerados, os resultados forneceram os scores de eficiência, que no caso da inversão de outputs e inputs, é denominada eficiência pessimista $E_{\text {pess }}$;

4. Inverteu-se o valor da eficiência pessimista encontrada: $1 / E_{\text {pess }}$;

5. Em seguida, os dados foram normalizados dividindo os evento de cada distribuição pelo evento de maior valor, obtendo-se índice de eficiência da fronteira invertida $E_{f i}$.

Posteriormente, foram calculados os índices combinados para cada modelo, e assim obtiveram-se inicialmente oito resultados de classificação. O índice combinado é obtido pela média aritmética dos scores de eficiência da fronteira clássica e da fronteira invertida.

Essa primeira análise tornou possível responder o questionamento de como as variáveis dos modelos se comportam quando orientadas para diferentes objetivos - 
minimização dos inputs ou maximização dos outputs. Tratando-se de modelos com retornos variáveis de escala - BCC, pode-se observar que houve variação na eficiência média da fronteira clássica de eficiência, mas a quantidade de DMU's presentes nesta fronteira foram as mesmas, independente da orientação. Quanto aos modelos de retornos constantes de escala CCR, os resultados foram exatamente os mesmos, independente da orientação.

\begin{tabular}{|c|c|c|c|c|}
\hline \multicolumn{5}{|l|}{ Eficiência Média } \\
\hline Modelo & CCR input & CCR output & BCC input & BCC output \\
\hline Completo & $72,50 \%$ & $72,50 \%$ & $79,77 \%$ & $85,53 \%$ \\
\hline Sem Sinistralidade & $51,24 \%$ & $51,24 \%$ & $60,10 \%$ & $85,04 \%$ \\
\hline Sem Independência Financeira & $62,92 \%$ & $62,92 \%$ & $72,02 \%$ & $82,35 \%$ \\
\hline Sem Endividamento & $46,16 \%$ & $46,16 \%$ & $52,77 \%$ & $79,49 \%$ \\
\hline Sem Rentabilidade do patrimônio Líquido & $67,82 \%$ & $67,82 \%$ & $77,80 \%$ & $81,14 \%$ \\
\hline Sem Margem Operacional & $68,01 \%$ & $68,01 \%$ & $78,95 \%$ & $77,54 \%$ \\
\hline Sem Prêmios Ganhos & $67,76 \%$ & $67,76 \%$ & $75,77 \%$ & $83,85 \%$ \\
\hline Sem Endividamento, Margem Operacional e Premios Ganhos & $37,90 \%$ & $37,90 \%$ & $45,17 \%$ & $62,50 \%$ \\
\hline Sem Margem Operacional e Premios Ganhos & $63,41 \%$ & $63,41 \%$ & $75,05 \%$ & $75,59 \%$ \\
\hline Sem Independência Financeira, Margem Operacional e prêmios Ganhos & $55,74 \%$ & $55,74 \%$ & $67,81 \%$ & $74,40 \%$ \\
\hline Sem Endividamento, Independência Financeira e Prêmios Ganhos & $1,01 \%$ & $1,01 \%$ & $6,36 \%$ & $75,19 \%$ \\
\hline Sem Endividamento, Independência Financeira e Margem Operacional & $13,17 \%$ & $13,17 \%$ & $15,34 \%$ & $63,51 \%$ \\
\hline
\end{tabular}

Tabela 4 - Eficiência média dos modelos

\begin{tabular}{|c|c|c|c|c|}
\hline \multicolumn{5}{|c|}{ Quantidade de DMU's eficientes } \\
\hline Modelo & CCR input & CCR output & BCC input & BCC output \\
\hline Completo & 18 & 18 & 25 & 25 \\
\hline Sem Sinistralidade & 11 & 11 & 24 & 24 \\
\hline Sem Independência Financeira & 8 & 8 & 11 & 11 \\
\hline Sem Endividamento & 7 & 7 & 11 & 11 \\
\hline Sem Rentabilidade do patrimônio Líquido & 15 & 15 & 20 & 20 \\
\hline Sem Margem Operacional & 16 & 16 & 22 & 22 \\
\hline Sem Prêmios Ganhos & 12 & 12 & 20 & 20 \\
\hline Sem Endividamento, Margem Operacional e Premios Ganhos & 3 & 3 & 4 & 4 \\
\hline Sem Margem Operacional e Premios Ganhos & 10 & 10 & 17 & 17 \\
\hline Sem Independência Financeira, Margem Operacional e prêmios Ganhos & 5 & 5 & 12 & 11 \\
\hline Sem Endividamento, Independência Financeira e Prêmios Ganhos & 1 & 1 & 4 & 4 \\
\hline Sem Endividamento, Independência Financeira e Margem Operacional & 2 & 2 & 4 & 4 \\
\hline
\end{tabular}

Tabela 5 - Quantidade de DMU's eficientes dos modelos

Observou-se que o modelo BCC orientado para a maximização dos outputs apresentou o melhor desempenho em ambos os parâmetros, com 85,53\% de eficiência média, e vinte e cinco DMU's eficientes.

Em seguida, foi realizada uma análise de correlação para avaliar a correlação entre as posições ocupadas por todas DMU's no ranking original da Revista Conjuntura Econômica e no ranking oriundo da aplicação da técnica DEA. A partir da análise de correlação também pôde-se comparar o comportamento dos rankings oriundos das aplicações que consideraram a ponderação da base de dados original e das aplicações que não consideraram os pesos propostos. 


\begin{tabular}{|c|c|c|c|c|}
\hline \multicolumn{5}{|c|}{ Coeficiente de Correlaçào } \\
\hline Modelo & CCR input & CCR output & BCC input & BCC output \\
\hline Completo & 0,4895 & 0,4895 & 0,5022 & 0,5037 \\
\hline Sem Sinistralidade & 0,3697 & 0,3697 & 0,4084 & 0,5057 \\
\hline Sem Independência Financeira & 0,2872 & 0,2872 & 0,3194 & 0,3842 \\
\hline Sem Endividamento & 0,6074 & 0,6074 & 0,5818 & 0,5281 \\
\hline Sem Rentabilidade do patrimônio Líquido & 0,5738 & 0,5738 & 0,4934 & 0,4896 \\
\hline Sem Margem Operacional & 0,5892 & 0,5892 & 0,5345 & 0,3975 \\
\hline Sem Prêmios Ganhos & 0,1686 & 0,1686 & 0,1917 & 0,2831 \\
\hline Sem Endividamento, Margem Operacional e Premios Ganhos & 0,4419 & 0,4419 & 0,3451 & 0,2215 \\
\hline Sem Margem Operacional e Premios Ganhos & 0,3174 & 0,3174 & $-0,1103$ & 0,2253 \\
\hline Sem Independência Financeira, Margem Operacional e prêmios Ganhos & $-0,0608$ & $-0,0608$ & $-0,1918$ & 0,0620 \\
\hline Sem Endividamento, Independência Financeira e Prêmios Ganhos & 0,0029 & 0,0029 & 0,0885 & 0,1931 \\
\hline Sem Endividamento, Independência Financeira e Margem Operacional & 0,8818 & 0,8818 & 0,7427 & 0,3856 \\
\hline
\end{tabular}

Tabela 6 - Coeficiente de correlação DEA versus Base de Dados sem ponderação

\begin{tabular}{|c|c|c|c|c|}
\hline \multicolumn{5}{|c|}{ Coeficiente de Correlaçào } \\
\hline Modelo & CCR input & CCR output & BCC input & BCC output \\
\hline Completo & 0,4895 & 0,4895 & 0,5022 & 0,5037 \\
\hline Sem Sinistralidade & 0,3697 & 0,3697 & 0,4084 & 0,5057 \\
\hline Sem Endividamento & 0,6074 & 0,6074 & 0,5818 & 0,5281 \\
\hline Sem Rentabilidade do patrimônio Líquido & 0,5738 & 0,5738 & 0,4934 & 0,4896 \\
\hline Sem Margem Operacional & 0,5892 & 0,5892 & 0,5345 & 0,3975 \\
\hline Sem Endividamento, Margem Operacional e Premios Ganhos & 0,4419 & 0,4419 & 0,3451 & 0,2215 \\
\hline Sem Margem Operacional e Premios Ganhos & 0,3174 & 0,3174 & $-0,1103$ & 0,2253 \\
\hline Sem Independência Financeira, Margem Operacional e prêmios Ganhos & $-0,0608$ & $-0,0608$ & $-0,1918$ & 0,0620 \\
\hline Sem Endividamento, Independência Financeira e Prêmios Ganhos & 0,0029 & 0,0029 & 0,0885 & 0,1931 \\
\hline Sem Endividamento, Independência Financeira e Margem Operacional & 0,8818 & 0,8818 & 0,7427 & 0,3856 \\
\hline
\end{tabular}

Tabela 7 - Coeficiente de correlação DEA versus Base de Dados com ponderação.

Nesta análise, os modelos BCC que não contemplaram a variável Endividamento apresentaram os maiores coeficientes correlação dentre os considerados. No entanto, o estudo defrontou a seguinte questão. O que seria mais interessante a se considerar: o modelo BCC orientado para a maximização dos outputs completo, com eficiência média de 85,83\%, 25 DMU's eficientes e coeficiente de correlação igual à 0,5037 , ou o modelo BCC orientado para a maximização dos outputs sem a variável Endividamento, com 79,49\% de eficiência média, 11 DMU's eficientes e coeficiente de correlação $0,5818 ?$

Diante das constatações realizadas até este momento, optou-se por abrir mão do maior coeficiente de correlação dentre os obtidos para ganhar em eficiência média e quantidade de DMU's eficientes. Esta decisão se apóia ainda no fato de a diferença entre os coeficientes de correlação ser consideravelmente sutil.

Outro importante aspecto que pôde ser observado por meio da análise dos modelos gerados foi que a incorporação dos pesos considerados pela publicação original não exerceu influência alguma na análise. Os resultados obtidos com ponderação foram exatamente iguais aos resultados obtidos aos resultados oriundos das análises sem considerar os pesos propostos 
pela Revista Conjuntura Econômica. Isto se explica pela razão de apenas dois dos indicadores considerados no modelo apresentarem ponderação maior que 1,0 (um), sendo estes Rentabilidade do Patrimônio Líquido e Prêmios Ganhos. Assim, tratando-se de modelos de otimização, a variação escalar dos valores mantém a mesma sensibilidade quando considerada dentro de um mesmo universo de dados. Portanto, o peso para tal indicador poderia representar um valor qualquer, que o comportamento dos dados de todos os indicadores em conjunto seria o mesmo.

Dando continuidade à busca pelo modelo que melhor se adequasse à aplicação, foi elaborada a tabela a seguir, que informa quantidade de posições iguais, ou seja, a quantidade de DMU's que ocuparam a mesma posição em ambas as classificações - DEA versus Revista Conjuntura Econômica.

\begin{tabular}{|l|c|c|c|}
\hline \multicolumn{2}{|c|}{ Posições iguais - DEA versus Revista Conjuntura Econômica } \\
\hline Modelo & CCR input & CCR output & BCC input \\
\hline BCC output \\
\hline Completo & 1 & 1 & 1 \\
\hline Sem Sinistralidade & 3 & 3 & 1 \\
\hline Sem Independência Financeira & 2 & 2 & 1 \\
\hline Sem Endividamento & 2 & 2 & 1 \\
\hline Sem Rentabilidade do patrimônio Líquido & 5 & 5 & 2 \\
\hline Sem Margem Operacional & 2 & 2 & 2 \\
\hline Sem Prêmios Ganhos & 2 & 1 \\
\hline Sem Endividamento, Margem Operacional e Premios Ganhos & 2 & 3 \\
\hline Sem Margem Operacional e Premios Ganhos & 1 & 1 & 2 \\
\hline Sem Independência Financeira, Margem Operacional e Prêmios Ganhos & 2 & 0 & 1 \\
\hline Sem Endividamento, Independência Financeira e Prêmios Ganhos & 2 & 2 & 1 \\
\hline Sem Endividamento, Independência Financeira e Margem Operacional & 2 & 2 & 1 \\
\hline
\end{tabular}

Tabela 8 - Posições iguais DEA versus Base de Dados

A tabela de posições semelhantes apresenta a quantidade de eventos coincidentes ao se comparar cada intervalo de dezena do ranking oriundo do estudo realizado pela Fundação Getúlio Vargas e do ranking oriundo da técnica DEA.

\begin{tabular}{|c|c|c|c|c|}
\hline \multicolumn{5}{|c|}{ Posições semelhantes - DEA versus Revista Conjuntura Econômica } \\
\hline Modelo & CCR input & CCR output & BCC input & BCC output \\
\hline Completo & 14 & 14 & 14 & \begin{tabular}{|l|l}
20 \\
\end{tabular} \\
\hline Sem Sinistralidade & 17 & 17 & 16 & 18 \\
\hline Sem Independência Financeira & 14 & 14 & 10 & 14 \\
\hline Sem Endividamento & 24 & 24 & 27 & 19 \\
\hline Sem Rentabilidade do patrimônio Líquido & 21 & 21 & 15 & 16 \\
\hline Sem Margem Operacional & 19 & 19 & 19 & 16 \\
\hline Sem Prêmios Ganhos & 12 & 12 & 13 & 17 \\
\hline Sem Endividamento, Margem Operacional e Premios Ganhos & 18 & 18 & 16 & 18 \\
\hline Sem Margem Operacional e Premios Ganhos & 16 & 16 & 6 & 9 \\
\hline Sem Independência Financeira, Margem Operacional e prêmios Ganhos & 7 & 7 & 8 & 9 \\
\hline Sem Endividamento, Independência Financeira e Prêmios Ganhos & 10 & 10 & 7 & 14 \\
\hline Sem Endividamento, Independência Financeira e Margem Operacional & 76 & 76 & 36 & 17 \\
\hline
\end{tabular}

Tabela 9 - Posições semelhantes DEA versus Base de Dados sem ponderação

Nesta última análise, o desempenho dos modelos também foi melhor nas opções de modelos de retornos variáveis de escala com orientação para a maximização de outputs. 
Assim, com todos estes passos realizados objetivando mapear o comportamento do modelo perante a presença e/ou ausência de algumas variáveis, determinou-se então que, para se obter um retrato da realidade que se objetiva atingir, o modelo mais indicado seria o de retornos variáveis de escala, e com orientação para a maximização dos outputs. Esta escolha se deveu aos seguintes motivos:

1. Os dados não se comportam de forma linear, e por isso o retorno constante atribuído ao modelo CCR não pode ser aplicado ao caso; e

2. Ao se analisar os indicadores considerados, entende-se que os objetivos de empresas da natureza de seguradoras esteja mais voltado para a maximização dos resultados do que para a minimização da utilização de seus recursos. Com base no argumento que as empresas seguradoras enriquecem por meio da aplicação de suas reservas no mercado financeiro, entende-se que elas procuram a maximização de suas riquezas ante a redução do uso de recursos. Daí a orientação para a maximização das saídas.

Uma vez definido o modelo com base nos ajustes e simulações realizadas, optou-se por utilizar o modelo BCC orientado para a maximização dos outputs. Para garantir que estavam sendo contempladas todas as variáveis de forma correta, realizou-se o a seleção das variáveis pelo procedimento denominado Stepwise.

\subsubsection{Seleção das variáveis}

As variáveis consideradas nos modelos desenvolvidos foram os mesmos indicadores utilizados pela publicação original que estabeleceu o ranking de empresas componentes do setor de seguros privados. Esta decisão foi tomada procurando dar uma maior credibilidade à comparação entre as três propostas de ranking - original da revista, oriundo da aplicação DEA e oriundo da rede neural.

É importante notar que os indicadores levados em consideração para a criação do ranking são obtidos de dados contábeis, presentes na Demonstração de Resultados do Exercício, em Balanços Patrimoniais das empresas e em relatórios operacionais.

Plocket (1991) afirma que a composição dos indicadores torna-se mais importante ao destacar quais variáveis influenciam em um dado modelo econômico. Os indicadores adotados por esta pesquisa utilizam dados que influenciam o ramo de negócio em seus 
direcionamentos futuros - montante de ativos, faturamento, endividamento, patrimônio líquido entre outros. As variáveis que compõem os indicadores apresentam efeitos sensíveis nas tomadas de decisões e apresentam obscuras informações, se analisadas de forma individual, não destoando das tradicionais análises contábeis.

Dentre as diversas possibilidades que a utilização de indicadores propicia, Horn (1990) ressalta que os indicadores podem identificar aspectos como:

- Informações apresentada em uma série no tempo ou um ponto no tempo;

- Comparação entre componentes estruturais, entendida para efeito deste trabalho como, por exemplo, comparação entre departamentos de uma mesma unidade;

- Comparação entre diferentes entidades, entendida para esta pesquisa como comparação entre diferentes empresas.

Por fim, cabe mencionar que um sistema de indicadores tem o papel de delimitar o caminho percorrido pela unidade avaliada, demonstrando seu comportamento em um determinado instante, e facilitar a avaliação da viabilidade de se atingir os objetivos e metas pré-estabelecidos. Esta pesquisa propõe a utilização dos indicadores descritos anteriormente como dados de alimentação às técnicas utilizadas, com o objetivo de incrementar a acurácia dos resultados frutos de suas análises.

Norman e Stoker (1991) desenvolveram o procedimento para seleção de variáveis denominado Stepwise - passo à passo, com o objetivo de obedecer ao princípio de máxima relação causal entre inputs e outputs. O método se fundamenta em um par de input-output essencial, calcula o score de eficiência das DMU's em análise com base neste par, e em seguida, determina os coeficientes de correlação de todas as demais variáveis com estes scores. Para dar seqüência à inclusão de mais variáveis, seja ela input ou output, as demais variáveis são gradativamente adicionadas no modelo.

Em alguns casos, algumas variáveis contribuem pouco para a eficiência média do modelo. Sendo assim, uma vez identificadas podem ser retiradas no modelo, com base na avaliação da eficiência média da fronteira de eficiência clássica.

Assim, para cada possível combinação de variáveis, foram gerados diferentes modelos BCC com orientação para maximizar outputs, e a partir destes, foram levantadas informações sobre a eficiência média da fronteira clássica, a quantidade de DMU's eficientes e o coeficiente de correlação, com base na seguinte sistemática: 
1. Foram definidas como variáveis essenciais do modelo a sinistralidade como input essencial e rentabilidade do patrimônio líquido como output essencial;

2. Foram estabelecidas todas as possibilidades de combinações de variáveis, considerando as seguintes restrições: a) as variáveis essenciais devem estar sempre presentes nas combinações; e b) A técnica DEA necessita de pelo menos três variáveis para ser válida;

3. Foi calculado para todas as possibilidades a fronteira de eficiência clássica, a fronteira invertida de eficiência, o índice combinado e a eficiência média da fronteira clássica;

4. Gradativamente foram sendo adicionadas ao modelo as demais variáveis consideradas no estudo;

5. Para cada nova variável incorporada na análise, foi determinada a fronteira de eficiência clássica, a fronteira invertida de eficiência, o índice combinado e a eficiência média da fronteira clássica de eficiência;

Assim, além dos modelos gerados no passo anterior com o intuito de se identificar qual tipo de retorno e orientação deveriam ser utilizados, foram gerados mais quinze modelos diferentes com objetivo de identificar o comportamento do modelo BCC orientado para a maximização dos outputs dentro do procedimento Stepwise. 


\begin{tabular}{|c|c|c|c|c|}
\hline \multicolumn{5}{|c|}{ BCC max Outputs } \\
\hline Variáveis & \begin{tabular}{|c|}
$\begin{array}{c}\text { Eficiência } \\
\text { Média }\end{array}$ \\
\end{tabular} & \begin{tabular}{|c|} 
DMU's \\
Eficientes \\
\end{tabular} & $\begin{array}{l}\text { Correlação de } \\
\text { Pearson }\end{array}$ & $\begin{array}{l}\text { Correlação de } \\
\text { Spearman }\end{array}$ \\
\hline 1.Todas & $85,53 \%$ & 25 & 0,5037 & 0,5037 \\
\hline $\begin{array}{l}\text { 2.Sinistralidade, Independência Financeira e } \\
\text { Rentabilidade do PL }\end{array}$ & $62,50 \%$ & 4 & 0,2215 & 0,2215 \\
\hline $\begin{array}{l}\text { 3.Sinistralidade, Independência Financeira, } \\
\text { Endividamento e Rentabilidade do PL }\end{array}$ & $75,59 \%$ & 17 & 0,2253 & 0,2253 \\
\hline $\begin{array}{l}\text { 4.Sinistralidade, Independência Financeira, } \\
\text { Endividamento e Rentabilidade do PL, Margem } \\
\text { Operacional }\end{array}$ & $83,85 \%$ & 20 & 0,2831 & 0,2831 \\
\hline 5. Sinistralidade Endividamento Rentabilidade do PL & $74,40 \%$ & 11 & 0,0620 & 0,0620 \\
\hline $\begin{array}{l}\text { 6. Sinistralidade Rentabilidade do PL Margem } \\
\text { Operacional }\end{array}$ & $75,19 \%$ & 4 & 0,1931 & 0,1931 \\
\hline 7.Sinistralidade Rentabilidade do PL Prêmios Ganhos & $63,51 \%$ & 4 & 0,3856 & 0,3856 \\
\hline $\begin{array}{l}\text { 8.Sinistralidade Rentabilidade do PL Margem } \\
\text { Operacional Prêmios Ganhos }\end{array}$ & $76,74 \%$ & 6 & 0,4634 & 0,4634 \\
\hline $\begin{array}{l}\text { 9.Sinistralidade Independência Financeira } \\
\text { Rentabilidade do PL Margem Operacional } \\
\end{array}$ & $77,71 \%$ & 7 & 0,2343 & 0,2343 \\
\hline $\begin{array}{l}\text { 10. Sinistralidade Independência Financeira } \\
\text { Rentabilidade do PL Prêmios Ganhos }\end{array}$ & $64,88 \%$ & 8 & 0,4698 & 0,4698 \\
\hline $\begin{array}{l}\text { 11. Sinistralidade Endividamento Rentabilidade do PL } \\
\text { Margem Operacional }\end{array}$ & $80,88 \%$ & 14 & 0,0247 & 0,0247 \\
\hline $\begin{array}{l}\text { 12.Sinistralidade Endividamento Rentabilidade do PL } \\
\text { Prêmios Ganhos }\end{array}$ & $75,53 \%$ & 14 & 0,3124 & 0,3124 \\
\hline $\begin{array}{l}\text { 13.Sinistralidade Endividamento Rentabilidade do PL } \\
\text { Margem Operacional Prêmios Ganhos }\end{array}$ & $82,35 \%$ & 17 & 0,3842 & 0,3842 \\
\hline $\begin{array}{l}\text { 14. Sinistralidade Independência Financeira } \\
\text { Rentabilidade do PL Margem Operacional Prêmios } \\
\text { Ganhos }\end{array}$ & $79,49 \%$ & 11 & 0,5281 & 0,5281 \\
\hline $\begin{array}{l}\text { 15.Sinistralidade Independência Financeira } \\
\text { Endividamento Rentabilidade do PL Prêmios Ganhos }\end{array}$ & $77,54 \%$ & 22 & 0,3975 & 0,3975 \\
\hline
\end{tabular}

Tabela 10 - Modelos BCC orientado para a maximização dos outputs para Stepwise

Além da correlação de Spearman, foi calculado também o coeficiente de correlação de Pearson. O coeficiente de correlação de Spearman é bastante utilizado para verificar o grau de correlação entre grandezas ordinais, e por isso foi considerado como uma alternativa ao $R$ de Pearson, quando neste último não se enquadra em distribuições normais.

O coeficiente de correlação de Spearman é calculado por meio da seguinte expressão:

$$
R=1-\frac{6 \sum_{i=1}^{n} d_{i}^{2}}{n\left(n^{2}-1\right)}
$$

No entanto, pode-se observar que, sendo o coeficiente de Spearman igual ao coeficiente de Pearson, os dados das distribuições podem ser representado por curvas normais. 
Diante dos resultados obtidos com o procedimento Stepwise, confirmou-se o que se havia levantado na etapa de ajuste do modelo: a melhor opção dentro das possibilidades seria o modelo BCC orientado para a maximização dos outputs, contemplando todas as variáveis apresentadas.

\subsection{Aplicação de Redes Neurais Artificiais}

Dando seqüência ao que foi proposto como solução para o problema de pesquisa, aplicou-se a técnica de Redes Neurais Artificiais para se estabelecer um ranking que classificasse as empresas do setor de seguros privados por meio de uma técnica matemática não-paramétrica. Os indicadores considerados foram os mesmos considerados pela Revista Conjuntura Econômica em sua publicação citada anteriormente, e também os mesmos considerados pela aplicação da técnica de Análise por Envoltória de dados.

Em poucas palavras, e com o objetivo de fornecer uma noção geral de como a rede neural operou ao longo dos experimentos, pode-se descrever processo da seguinte forma. Estabeleceram-se duas empresas fictícias. Uma empresa fictícia foi tida como ideal, considerando o seu desempenho dentro dos seis indicadores. A outra foi estabelecida com base no pior desempenho possível. A partir de então, todas as demais - empresas componentes do banco de dados - foram comparadas, por meio do cálculo da distância euclidiana em um espaço de seis dimensões, com as empresas fictícias de melhor e pior desempenho. A que mais se aproximou da empresa ideal, e que mais se distanciou da de pior desempenho, foi classificada como primeiro lugar do ranking, e assim sucessivamente.

Dois fatos enfatizam a redução da subjetividade obtida por esta aplicação. O primeiro está relacionado à técnica utilizada. Redes neurais artificiais trata-se de uma técnica nãoparamétrica. O segundo fato encosta-se sobre a rede neural escolhida para aplicação, os mapas auto-organizáveis de Kohonen. Este tipo de arquitetura pertence ao grupo das redes que possuem um padrão de treinamento não-supervisionado, o que significa que as informações de saída obtidas com a técnica não são comparadas com um grupo de saída pré-estabelecido para o modelo, deixando aberta toda e qualquer possibilidade de resultado.

A seguir, o método para esta aplicação será descrito em todas as suas minúcias. Será detalhada a maneira como a técnica de redes neurais artificiais foi utilizada com o objetivo de obter um ranking de empresas que compõem o setor de seguros privados. 


\subsubsection{Desenvolvimento da Rede Neural}

A primeira iniciativa alinhada à obtenção dos resultados, assim como na aplicação da técnica DEA, foi dada com o processo de padronização dos dados. Os dados retirados diretamente da publicação referência foram tratados de forma que estes se encaixassem em um intervalo entre zero e um.

Assim, obteve-se a distribuição de dados dentro de um intervalo adequado às funções que foram usadas posteriormente no método, sem alterar a distribuição dos mesmos no espaço.

Em seguida, deu-se início à elaboração de um programa no software Matlab para se viabilizar obtenção de um ranking de empresas por meio do uso de um mapa auto-organizável de Kohonen. Para isso, foi utilizada a tool box do Matlab voltada para a aplicação de redes neurais. As linhas de código do programa podem ser encontradas no anexo B.

Um ponto importante que deve ser ressaltado refere-se à quantidade de casas decimais dos dados. Ao normalizar dados com dimensões escalares variadas, o banco de dados encaixou-se em um intervalo entre zero e um com vasta quantidade de casas decimais. $\mathrm{O}$ software Matlab considera um determinado número de casas decimais, de acordo com as funções que estão sendo utilizadas. Foram necessários alguns testes para que os dados normalizados pudessem ser alimentados no programa sem que nenhuma informação importante sobre os eventos fosse desperdiçada.

Assim, a matriz de dados normalizados em um arquivo do $M S$ Excel foi inserida no programa por meio da criação da variável $P$. Foi necessário definir a matriz transposta de dados para que o programa pudesse reconhecer as informações da maneira correta - as variáveis nas linhas e padrões nas colunas da matriz. Cada linha foi transformada em um vetor de seis dimensões que caracteriza as informações das empresas analisadas com base nos indicadores considerados.

Diante da orientação dos indicadores - quanto maior/menor, melhor, estabeleceu-se as variáveis $W_{\text {melhor }}$ como sendo $W_{\text {melhor }}=[1,1,1,0,0,1]$ o vetor representante de uma empresa fictícia com desempenho ideal em todos os indicadores considerados, e $W_{\text {pior }}=[0,0,0,1,1,0]$ como o vetor representante de uma empresa fictícia com o desempenho. 
Em seguida, foram calculados os valores máximos e mínimos dentro de cada distribuição - passo este que já havia sido realizado anteriormente no processo de padronização dos dados. Este passo se faz necessário para que a rede conheça a amplitude de dados com que está tratando. Estes valores calculados nesta etapa servirão como informações para iniciar os parâmetros da rede dentro do mapa auto-organizável, inseridas na programação por meio da variável $P R$ - parâmetros da rede.

Outros parâmetros também foram definidos neste estágio. Para o número de neurônios, um parâmetro importante para o modelo, foi considerado a quantidade de cem unidades processadoras, devido ao fato de a amostra conter informações de cem empresas diferentes. Os neurônios foram dispostos de forma linear, e não como via de regra o Matlab define, como sendo quadrática e de dimensão 5 x 8. Assim, inicialmente, a topologia da camada de neurônios foi definida como linear, com dimensão de 1 x 100. A quantidade de neurônios foi inserida no sistema por meio da variável $D i$.

Um ponto importante a se esclarecer sobre o comportamento da rede SOM aplicada neste trabalho é relacionado à forma como o neurônio vencedor se relaciona com os neurônios vizinhos. As formas mais difundidas nas aplicações, segundo Haykin (2001), são: a) influência hexagonal; b) influência quadrática e; c) influência linear.

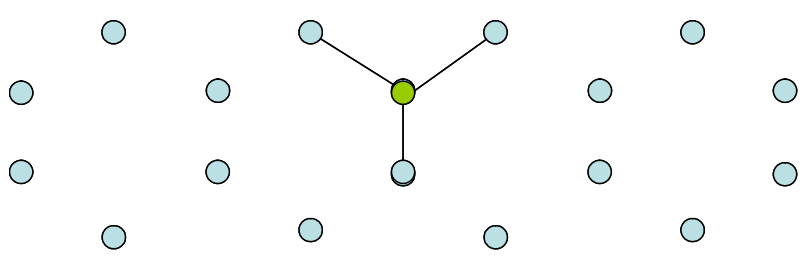

Figura 14 - Influência hexagonal

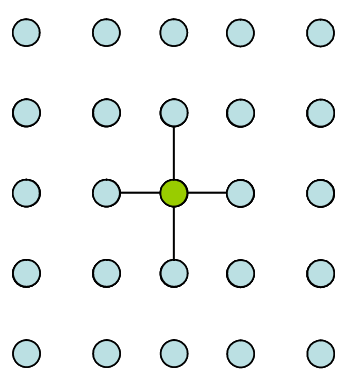

Figura 15 - Influência quadrática 
Figura 16 - Influência quadrática

Com o intuito de se obter o resultado a partir de um mapa topográfico amplo de neurônios, e também baseado na intenção de se treinar a rede da melhor forma possível, a forma escolhida de relacionamento do neurônio vencedor - o primeiro neurônio ativado em cada iteração, em sua vizinhança foi a hexagonal, que possibilita uma maior possibilidade de comunicação entre as unidades processadoras. Consequentemente, a função de treinamento escolhida para a aplicação foi a denominada HEXTOP, função componente da toolbox de redes neurais do Matlab, e inserida na programação por meio da variável TFCN - Topology Function.

Após definida a forma como o neurônio influenciaria sua vizinhança e a função do treinamento, apresentou-se ao programa a função que define a distância de atualização entre neurônio vencedor e seus vizinhos. Existem duas possibilidades: a função LINK DIST, que atualiza os pesos dos neurônios vizinhos simplesmente pelo fato de existir uma conexão com os mesmos, e a função DIST, que atualiza simplesmente pelo cálculo da distância linear. A função escolhida foi a LINK DIST, inserida no sistema por meio da variável DFCN-Distance Function. Esta escolha fundamenta-se no fato de estarmos trabalhando em seis dimensões, o que inviabiliza o cálculo da distância linear, e também na intenção de se atualizar o maior número de neurônios possíveis, obtendo um maior dinamismo da rede.

Cabe neste momento afirmar que para o cálculo da distância, foi considerada a expressão que define o cálculo da distância euclidiana.

$$
d(A, B)=\sqrt{\sum\left(x_{i}(A)-x_{i}(B)\right)^{2}}
$$

A taxa de aprendizagem da fase de ordenação atribuída à variável $O L R$ - ordering phase learning rate, e a taxa de aprendizagem da fase de especialização denominada TLR turning phase learning rate, foram incluídas como parâmetros da rede. As taxas de aprendizagem de ambas as fases - ordenação (treinamento) e especialização (convergência) foram definidas em valores abaixo do que o proposto pelo próprio algoritmo do Matlab, em razão de se ter a intenção de obter uma rede bem treinada. A taxa de aprendizado funciona como o passo em que a rede evolui em direção ao seu padrão de convergência adequado. Uma 
taxa de aprendizagem baixa indica que a rede caminhará mais lentamente em direção ao seu goal. No entanto, ao atingir seu goal, pode-se afirmar que a rede foi mais bem treinada que se tivesse sido adotada uma taxa de aprendizagem maior.

Já para atualização da vizinhança na fase de especialização, que pode ser também chamada de fase de convergência, a distância padrão inicial entre neurônios foi tida como 1 . Representado pela variável TND - turning phase neighborhood distance, este parâmetro representa apenas como os neurônios estão disposto antes de os dados serem alimentados no modelo e o algoritmo iniciado.

Abaixo segue um resumo com os parâmetros já apresentados anteriormente, e com mais alguns aspectos característicos da rede:

- Topologia: hexagonal;

- Função de treinamento: HEXTOP;

- Quantidade de neurônios: 100;

- Taxa de aprendizado (fase de treinamento): 0,05 (default: 0,9);

- Passos de ordenação (fase de especialização): 3000

- Taxa de aprendizagem (fase de convergência): 0,005 (default: 0,02);

- Distância padrão inicial entre neurônios: 1.

Neste momento valem duas ressalvas. A primeira envolve o fato de que os parâmetros todos da rede são interdependentes, e que esta relação não é genérica, e sim válida para o modelo em discussão. A segunda, mas não menos importante, afirma que existe um ponto de inversão, no qual reduzir a taxa de treinamento da rede não traz mais benefícios para o modelo. Para esta aplicação, esse ponto localizou-se entre 0,03 e 0,045.

Após definido os parâmetros descritos anteriormente, foi dado o comando ao algoritmo para criar a rede neural propriamente dita.

De acordo com a fundamentação teórica realizada, a rede escolhida para esta aplicação foi a rede SOM. Para definir esta escolha dentro da programação, entrou-se com o comando 
no Matlab denominado NEWSOM, seguido por todos os parâmetros definidos anteriormente: $n e t=N E W S O M(P R, D i, T F C N, D F C N$, OLR, OSTEPS $, T L R, T N D)$.

É válido afirmar que, mesmo sendo definidos parâmetros como a quantidade de neurônios, sua disposição ao longo do mapa auto-organizável e distância inicial, a distribuição dos neurônios considerando as características individuais é aleatória. Isso quer dizer que um determinado neurônio, com características particulares, pode ocupar posições espaciais diferentes em simulações distintas. Exemplificando, o neurônio mais próximo da origem dos eixos pode receber o título de "neurônio 11" em uma simulação, e o título de "neurônio 54" em outra. Isso faz com que, ao se utilizar o mesmo programa alimentado pelos mesmos dados, os resultados finais podem ser diferentes.

Com base nesta possibilidade, após padronizar os dados e terminar a etapa de programação, foi simulado os resultados obtidos por algumas vezes e calculado o coeficiente de correlação entre eles. Após seis simulações, obteve-se um modelo altamente correlacionado entre suas simulações. Isso significa que a rede já estaria bem treinada e que independente das vezes que se iniciassem a disposição aleatória dos neurônios, os resultados seria bastante similares.

\begin{tabular}{|l|c|c|c|c|c|c|}
\hline & Sim. I & Sim. II & Sim. III & Sim. IV & Sim. V & Sim. VI \\
\hline Simulação I & 1,0000 & 0,9655 & 0,9612 & 1,0000 & 0,9031 & 0,9597 \\
\hline Simulação II & 0,9655 & 1,0000 & 0,9575 & 0,9655 & 0,9059 & 0,9561 \\
\hline Simulação III & 0,9612 & 0,9575 & 1,0000 & 0,9612 & 0,8882 & 0,9441 \\
\hline Simulação IV & 1,0000 & 0,9655 & 0,9612 & 1,0000 & 0,9031 & 0,9597 \\
\hline Simulação V & 0,9031 & 0,9059 & 0,8882 & 0,9031 & 1,0000 & 0,8889 \\
\hline Simulação VI & 0,9597 & 0,9561 & 0,9441 & 0,9597 & 0,8889 & 1,0000 \\
\hline
\end{tabular}

Tabela 11 - Correlação entre simulações da Rede Neural

Com a Rede Neural ajustada, pode-se finalmente variar o último parâmetro. O número de épocas, que representa o número de iterações que o modelo realiza, foi inicialmente definido em 3.000. No entanto, observou-se que ao manter o número de épocas abaixo de 5.000 impactava-se no coeficiente de correlação do modelo. Assim, por meio de mais simulações, avaliou-se o comportamento da quantidade de épocas considerando dois parâmetros: tempo de convergência e grau de correlação. 


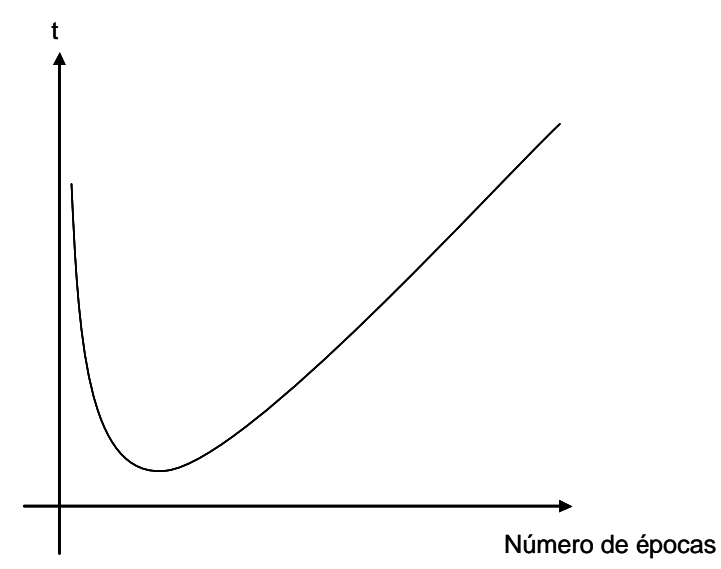

Figura 17 - Número de épocas versus Tempo de Convergência

Ao se considerar o número de épocas e o tempo de convergência, observou-se que com 7.000 épocas, já se obteve um tempo de convergência do modelo elevado para uma aplicação enxuta como esta, e um coeficiente de correlação 0,67. Com 9.000 épocas o modelo continuou com um tempo de convergência elevado, mas obteve-se um considerável incremento no grau de correlação, que atingiu 0,94. Já com 11.000 épocas, aumentou ainda mais o tempo de convergência, mas não houve nenhum aumento no coeficiente de correlação.

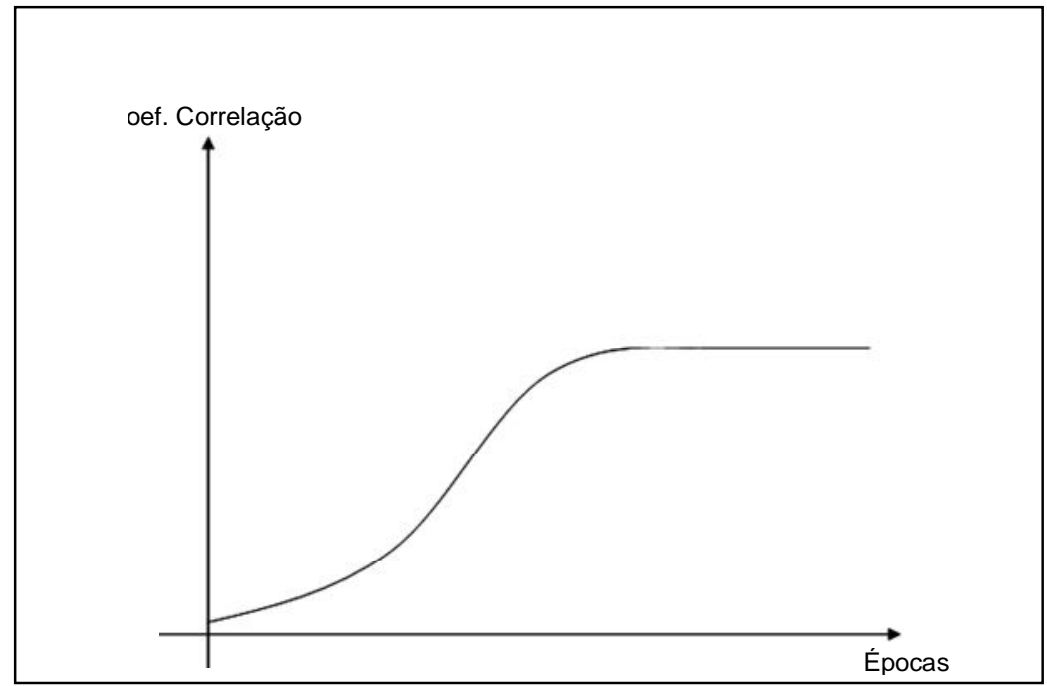

Figura 18 - Número de iterações versus Tempo de Convergência

Assim, chegou-se ao modelo tido como o mais adequado para classificar as empresas que compõem o banco de dados. A análise dos rankings obtidos foi descrita na seção Análise dos Resultados Obtidos. Nela, foi discorrido sobre o ranking oriundo das aplicações e analisado o comportamento das empresas entre os três rankings considerados - revista, DEA e RNA. 


\section{CAPÍTULO 5 - ANÁLISE DOS RESULTADOS OBTIDOS}

Por meio da aplicação da técnica de Análise por Envoltória de Dados e de Redes Neurais Artificiais, o trabalho chegou à resultados relevantes que contribuem para a elaboração de um ranking para o setor de seguros privados, sob uma perspectiva sinérgica de aproveitar os aspectos bem sucedidos de cada técnica aplicada, juntamente com aspectos apresentados pela base de dados consideradas neste trabalho.

A seguir serão apresentados e discutidos os resultados obtidos com a aplicação de DEA e RNA. No entanto, algumas ressalvas sobre o trabalho publicado pela Fundação Getúlio Vargas são exploradas, com o objetivo de se fundamentar ainda mais a metodologia utilizada.

\subsection{O ranking original}

O ranking original, divulgado anualmente desde 1999, é publicado por uma instituição com tradição em estudos sobre finanças e economia, a Fundação Getúlio Vargas. Adotado como ranking oficial pelo órgão regulador do setor, a Superintendência de Seguros Privados SUSEP, a publicação serve de orientação para stakeholders correlacionados com o setor de seguros privados, desde consumidores, funcionários do setor, empresas de uma forma geral e investidores ávidos por oportunidades de investimentos promissoras.

Vale deixar estritamente esclarecido que este trabalho não tem a intenção de criticar ou julgar a classificação que foi tida como referência. A idéia é encontrar possíveis formas de se contribuir com uma publicação que já conquistou seu espaço no meio acadêmico com base em seu respaldo de competência e contribuição para todos aqueles que usufruem de suas informações. O que se pretende com este trabalho é identificar maneiras de estruturar e adequar uma metodologia para elaboração de rankings que seja fundamentada em técnicas estruturadas, além de fazer uso dos conhecimentos específicos por parte dos pesquisadores. 
No entanto, alguns pontos podem ser levantados quanto ao método utilizado pelos pesquisadores Borges (2007) e Bueno (2006). Um importante aspecto a ser avaliado é a variação de indicadores e pesos ao longo do ano. Na publicação do mesmo ranking, mas no ano de 2006, os indicadores não foram os mesmos em sua totalidade. Houve também uma considerável variação nos pesos adotados para cada indicador.

\begin{tabular}{|l|c|l|c|}
\hline \multicolumn{2}{|c|}{2006} & \multicolumn{2}{c|}{ 2007 } \\
\hline \multicolumn{1}{|c|}{ Variáveis } & Peso & \multicolumn{1}{c|}{ Variáveis } & Peso \\
\hline Prêmios Ganhos & 1,50 & Prêmios Ganhos & 3,00 \\
\hline Rentabilidade do PL & 2,00 & Rentabilidade do PL & 2,50 \\
\hline Margem Operacional & 1,00 & Margem Operacional & 1,00 \\
\hline Sinistralidade & 1,00 & Endividamento & 1,00 \\
\hline Indice Combinado & 1,50 & Sinistralidade & 1,00 \\
\hline Independência Financeira & 1,00 & Independência Financeira & 1,00 \\
\hline
\end{tabular}

Tabela 12 - Comparação entre variáveis e pesos dos indicadores

Essa variação de parâmetros de julgamento abre margem para questionamentos como:

- Em 2006, no lugar de Endividamento, foi considerada a variável Índice Combinado, que mede o quanto gastos com sinistros e principais despesas representam em relação aos Prêmios Ganhos. Se o Índice Combinado exerceu um papel importante na ordenação das empresas ao possuir um peso de 1,50, por que não foi considerado na análise de 2007?

- Prêmios ganhos, que pode ser entendido também como um indicador do market share das empresas, dobrou de representatividade em apenas um ano, ao sair de um peso igual a 1,50 para 3,00. Mesmo diante das alterações macroeconômicas sofridas pelo setor, será que a alteração possui força suficiente para dobrar a representatividade desta variável na análise?

Sabe-se que o dinamismo da economia e do ambiente financeiro corporativo impõe mudanças bruscas e a tomada de respostas imediatas às empresas. No entanto, diante de mudanças relativamente importantes em um intervalo de doze meses, acredita-se ser necessária uma maior fundamentação sobre as variações de indicadores e pesos considerados, abordando inclusive os fatos que influenciaram para essas mudanças. Essa fundamentação não foi encontrada em nenhum dos artigos consultados. 
Ressalta-se neste momento que não faz parte dos objetivos deste artigo levantar os motivos que fizeram com que os parâmetros considerados pela Revista Conjuntura Econômica. Questionar os motivos desta variação seria bastante interessante, mas fica como escopo para outra pesquisa.

Um ponto importante que também merece atenção é sobre a influência que a variável Prêmios Ganhos exerce sobre o ranking publicado pela Revista Conjuntura Econômica. Ao analisar-se o ranking publicado pela Revista e compará-lo com o ranking das seguradoras ordenado apenas pela variável Prêmios Ganhos, obtêm-se apenas seis alterações na ordenação das cem unidades analisadas, sem grandes impactos na colocação das mesmas.

\begin{tabular}{|c|c|c|c|c|c|c|c|c|}
\hline 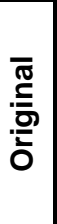 & 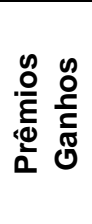 & DMU & 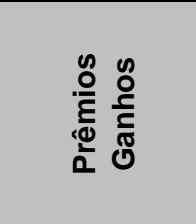 & 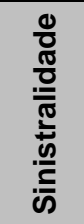 & 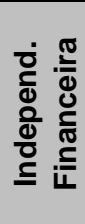 & $\begin{array}{l}\frac{\vec{c}}{0} \\
\frac{E}{J} \\
\frac{0}{0}\end{array}$ & 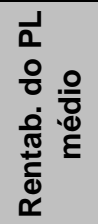 & 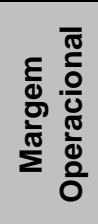 \\
\hline 1 & 1 & Bradesco Saúde & $3.561 .841,00$ & 0,93 & 0,40 & 0,51 & 0,12 & $(4,47)$ \\
\hline 2 & 2 & Porto Seguro & $2.469 .659,00$ & 0,50 & 0,31 & 0,99 & 35,08 & 6,19 \\
\hline 3 & 3 & Bradesco Auto/RE & $2.182 .166,00$ & 0,73 & 0,22 & 0,90 & 17,40 & $(6,84)$ \\
\hline 4 & 4 & Sul América Saúde & $1.939 .619,00$ & 0,74 & 0,53 & 0,33 & 23,70 & 6,46 \\
\hline 5 & 5 & Itaú Seguros & $1.891 .310,00$ & 0,51 & 0,67 & 0,18 & 32,73 & 6,67 \\
\hline 6 & 6 & Unibanco AIG & $1.820 .083,00$ & 0,46 & 0,29 & 1,19 & 22,96 & 4,48 \\
\hline 7 & 7 & Sul América & $1.581 .652,00$ & 0,62 & 0,34 & 0,87 & 8,10 & $(8,10)$ \\
\hline 8 & 8 & Sul América Cia. Seguro Saúde & $1.387 .520,00$ & 0,86 & 0,59 & 0,41 & 18,38 & 5,14 \\
\hline 9 & $\overline{9}$ & Mapfre Vera Cruz & $1.197 .409,00$ & 0,61 & 0,35 & 0,66 & 9,53 & $(0,79)$ \\
\hline 10 & 10 & Aliança do Brasil & $1.194 .353,00$ & 0,35 & 0,18 & 1,90 & 63,64 & 11,73 \\
\hline 11 & 11 & Tokio Marine & $1.135 .982,00$ & 0,63 & 0,35 & 0,54 & 14,57 & $(7,97)$ \\
\hline 12 & 17 & Caixa Seguradora & $962.112,00$ & 0,46 & 0,37 & 0,25 & 11,53 & $(0,74)$ \\
\hline 13 & 12 & AGF Brasil & $954.076,00$ & 0,52 & 0,38 & 0,75 & 41,38 & 24,90 \\
\hline 14 & 13 & BrasilVeículos & $846.076,00$ & 0,55 & 0,27 & 0,89 & 18,14 & $(2,23)$ \\
\hline 15 & 14 & Mapfre Vera Cruz V.P. & $784.243,00$ & 0,61 & 0,21 & 1,25 & 27,07 & 6,56 \\
\hline 16 & 15 & Liberty & $727.196,00$ & 0,47 & 0,22 & 0,74 & 10,43 & $(2,12)$ \\
\hline 17 & 16 & HDI Seguros & $699.630,00$ & 0,62 & 0,24 & 1,09 & 23,89 & $(5,29)$ \\
\hline 18 & 18 & Porto Seguro - Saúde & $609.608,00$ & 0,72 & 0,45 & 0,73 & 40,98 & 9,95 \\
\hline 19 & 19 & Marítima & $550.653,00$ & 0,52 & 0,32 & 0,91 & 13,18 & $(1,88)$ \\
\hline 20 & 20 & $\begin{array}{l}\text { Chubb } \\
\end{array}$ & $466.781,00$ & 0,49 & 0,38 & 0,40 & 15,53 & 1,44 \\
\hline 21 & 21 & HSBC Seguros & $421.804,00$ & 0,40 & 0,68 & 0,22 & 28,44 & 17,20 \\
\hline 22 & 22 & ACE & $407.968,00$ & 0,36 & 0,34 & 0,97 & 21,30 & 3,76 \\
\hline 23 & 23 & COSESP & $371.169,00$ & 0,59 & 0,33 & 0,61 & 8,70 & $(2,46)$ \\
\hline 24 & 24 & Indiana & $333.629,00$ & 0,63 & 0,21 & 0,93 & 20,22 & $(6,11)$ \\
\hline 25 & 25 & Sul América Seguros V.P & $319.342,00$ & 0,64 & 0,07 & 1,51 & $(4,69)$ & $(21,92)$ \\
\hline
\end{tabular}

Tabela 13 - Ranking ordenado apenas por Prêmios Ganhos

A empresa Caixa Seguros, ocupante da décima sétima colocação no ranking original, saltou para a décima segunda posição, empurrando as empresas que ocupavam a décima segunda, décima terceira, décima quarta, décima quinta e décima sexta para uma posição 
abaixo. Essa foi a única alteração ao se ordenar o grupo de empresas por ordem de Prêmios Ganhos.

A ordenação do ranking após a empresa HDI Seguros manteve-se o mesmo se comparado ao ranking original (Anexo A). Por este motivo, a tabela acima apresentou informações até a vigésima quinta posição. A função da tabela acima foi puramente apresentar as empresas que variaram de posição ao comparar o ranking original ao ranking obtido com a ordenação das empresas por Prêmios Ganhos.

Diante da pequena alteração no ranking ao se ordenar as empresas de acordo com o volume de Prêmios Ganhos, surge o seguinte questionamento: seriam as outras variáveis de importância reduzida, ou a forma como todas as seis variáveis foram consideradas é passível de melhoria?

Por meio da aplicação das técnicas propostas neste trabalho, pôde-se comprovar que as outras variáveis possuem um papel importante e devem ser consideradas com bastante cuidado ao se elaborar uma ordenação das empresas. Quesitos como grau de endividamento, independência e rentabilidade do patrimônio líquido possuem um papel importante no diagnóstico da situação financeira de qualquer empresa, independente do setor.

Especialmente falando do setor de seguros privados, a variável Rentabilidade do Patrimônio Líquido tem uma importância bastante considerável. Como se mencionou anteriormente, a fonte de alavancagem de recursos de empresas seguradoras está na aplicação das reservas não gastas com sinistros no mercado financeiro. E, sendo estas aplicações apontadas contabilmente como patrimônio líquido das empresas em seus Demonstrativos de Resultados do Exercício, uma empresa que apresenta uma rentabilidade do patrimônio líquido elevada deve possuir fortes indícios que apontem para boas condições financeiras.

Assim, a seguir, serão analisados os resultados das técnicas de Análise por Envoltória de Dados e Redes Neurais Artificiais considerando todas as variáveis propostas e desconsiderando as ponderações. Segundo os passos desenvolvidos na seção que tratou do método, a melhor opção para os modelos foi a que contemplou todas as variáveis. Também foi demonstrado que a presença dos fatores de ponderação dos indicadores não exerceu influência sobre as análises iniciais. 


\subsection{O ranking via Análise por Envoltória de Dados}

Após realizar uma análise dos modelos, análise esta que contemplou diversas combinações das variáveis consideradas, presença e ausência de ponderação, e adoção do método de seleção de variáveis por Stepwise, chegou-se a conclusão que o melhor modelo e a melhor combinação de variáveis a ser adotado seria o modelo com retornos variáveis de escala - BCC, orientado para maximização dos outputs, e contemplando todas as variáveis presentes na publicação original.

Ao aplicarmos o modelo descrito às variáveis originais, foi obtido o ranking a seguir:

\begin{tabular}{|c|c|c|c|}
\hline $\begin{array}{c}\text { Ranking } \\
\text { DEA }\end{array}$ & Empresa & Score DEA & $\begin{array}{c}\text { Ranking } \\
\text { Revista }\end{array}$ \\
\hline 1 & Safra Vida e Previdência & $100,00 \%$ & 58 \\
\hline 2 & Mapfre Nossa Caixa Vida e Previdência & $95,89 \%$ & 55 \\
\hline 3 & Icatu Hartford & $91,57 \%$ & 27 \\
\hline 4 & Alfa Previdência e Vida & $91,28 \%$ & 83 \\
\hline 5 & Assurant & $89,93 \%$ & 54 \\
\hline 6 & Santander Banespa & $89,69 \%$ & 76 \\
\hline 7 & PanAmericana & $89,29 \%$ & 50 \\
\hline 8 & HDI Seguros & $87,83 \%$ & 17 \\
\hline 9 & Caixa Seguradora & $86,98 \%$ & 12 \\
\hline 10 & Porto Seguro & $86,27 \%$ & 2 \\
\hline 11 & Unimed & $86,14 \%$ & 42 \\
\hline 12 & Safra & $85,38 \%$ & 92 \\
\hline 13 & Aliança do Brasil & $84,67 \%$ & 10 \\
\hline 14 & CONAPP & $84,39 \%$ & 67 \\
\hline 15 & Itaú Seguros & $83,63 \%$ & 5 \\
\hline 16 & Unibanco AIG & $83,51 \%$ & 6 \\
\hline 17 & American Life & $83,39 \%$ & 62 \\
\hline 18 & Notre Dame & $83,09 \%$ & 38 \\
\hline 19 & Banestes & $82,97 \%$ & 49 \\
\hline 20 & \begin{tabular}{|l|} 
MetLife \\
\end{tabular} & $82,89 \%$ & 45 \\
\hline 21 & Sul América Saúde & $82,80 \%$ & 4 \\
\hline 22 & AGF Saúde & $82,37 \%$ & 29 \\
\hline 23 & Bradesco Auto/RE & $82,30 \%$ & 3 \\
\hline 24 & Mapfre Vera Cruz Vida e Previdência & $82,17 \%$ & 15 \\
\hline 25 & Chubb & $81,72 \%$ & 20 \\
\hline 26 & MARES & $81,29 \%$ & 51 \\
\hline 27 & Sul América Seguros de Vida e Previdência & $80,77 \%$ & 25 \\
\hline 28 & Porto Seguro - Saúde & $80,63 \%$ & 18 \\
\hline 29 & ACE & $80,57 \%$ & 22 \\
\hline 30 & HSBC Seguros & $80,42 \%$ & 21 \\
\hline 31 & Unimed Saúde & $79,62 \%$ & 34 \\
\hline 32 & Azul & $79,12 \%$ & 31 \\
\hline 33 & Cardif & $78,60 \%$ & 48 \\
\hline 34 & Federal Vida e Previdência & $78,41 \%$ & 88 \\
\hline 35 & BrasilVeículos & $78,39 \%$ & 14 \\
\hline
\end{tabular}




\begin{tabular}{|c|c|c|c|}
\hline 36 & J. Malucelli & $78,21 \%$ & 73 \\
\hline 37 & Bradesco Saúde & $78,11 \%$ & 1 \\
\hline 38 & AGF Brasil & $78,01 \%$ & 13 \\
\hline 39 & Minas Brasil & $77,95 \%$ & 28 \\
\hline 40 & Zurich & $77,82 \%$ & 47 \\
\hline 41 & Tokio Marine & $77,71 \%$ & 11 \\
\hline 42 & Sinaf & $77,63 \%$ & 71 \\
\hline 43 & Unibanco AIG Saúde & $77,51 \%$ & 39 \\
\hline 44 & Santa Catarina & $77,29 \%$ & 77 \\
\hline 45 & Mapfre Vera Cruz & $77,19 \%$ & 9 \\
\hline 46 & Prudential & $76,55 \%$ & 60 \\
\hline 47 & Sul América & $76,20 \%$ & 7 \\
\hline 48 & Alfa & $76,10 \%$ & 40 \\
\hline 49 & \begin{tabular}{|l|} 
Marítima \\
\end{tabular} & $76,01 \%$ & 19 \\
\hline 50 & Sul América Cia. Seguro Saúde & $75,56 \%$ & 8 \\
\hline 51 & Bradesco Seguros & $75,54 \%$ & 44 \\
\hline 52 & Royal \& Sunalliance & $75,48 \%$ & 36 \\
\hline 53 & Yasuda & $75,32 \%$ & 37 \\
\hline 54 & Liberty & $75,21 \%$ & 16 \\
\hline 55 & Marítima Saúde & $75,12 \%$ & 30 \\
\hline 56 & Indiana & $75,11 \%$ & 24 \\
\hline 57 & COSESP & $74,80 \%$ & 23 \\
\hline 58 & Santander & $74,30 \%$ & 46 \\
\hline 59 & Itauseg Saúde & $74,30 \%$ & 53 \\
\hline 60 & Paraná & $74,30 \%$ & 64 \\
\hline 61 & $\mathrm{BCS}$ & $74,30 \%$ & 86 \\
\hline 62 & Kyoei & $74,30 \%$ & 93 \\
\hline 63 & Salutar Saúde & $74,30 \%$ & 94 \\
\hline 64 & AVS & $74,30 \%$ & 98 \\
\hline 65 & Federal & $74,15 \%$ & 59 \\
\hline 66 & Tokio Marine Brasil & $73,38 \%$ & 32 \\
\hline 67 & Centauro & $72,99 \%$ & 80 \\
\hline 68 & Previdência do Sul & $72,44 \%$ & 52 \\
\hline 69 & Sabemi & $72,35 \%$ & 65 \\
\hline 70 & Sulina & $72,18 \%$ & 63 \\
\hline 71 & SBCE & $72,14 \%$ & 95 \\
\hline 72 & Rural & $72,02 \%$ & 91 \\
\hline 73 & Nobre & $71,90 \%$ & 57 \\
\hline 74 & BrasilSaúde & $71,87 \%$ & 43 \\
\hline 75 & MBM & $71,74 \%$ & 74 \\
\hline 76 & Itaú XL & $70,21 \%$ & 72 \\
\hline 77 & Coface & $69,52 \%$ & 90 \\
\hline 78 & AIG Brasil & $69,44 \%$ & 66 \\
\hline 79 & Gralha Azul & $69,20 \%$ & 70 \\
\hline 80 & Excelsior & $68,66 \%$ & 69 \\
\hline 81 & Generali & $67,74 \%$ & 33 \\
\hline 82 & Java Nordeste & $66,53 \%$ & 89 \\
\hline 83 & Aliança da Bahia & $66,37 \%$ & 61 \\
\hline 84 & \begin{tabular}{|l|} 
Vida \\
\end{tabular} & $66,06 \%$ & 56 \\
\hline 85 & Gente & $65,99 \%$ & 81 \\
\hline 86 & UBF & $65,95 \%$ & 84 \\
\hline 87 & QBE & $65,84 \%$ & 68 \\
\hline 88 & Previmax & $65,76 \%$ & 87 \\
\hline
\end{tabular}




\begin{tabular}{|c|l|r|c|}
\hline 89 & Mutual & $65,68 \%$ & 78 \\
\hline 90 & Gerling Sul América & $65,56 \%$ & 75 \\
\hline 91 & Confiança & $65,13 \%$ & 35 \\
\hline 92 & APS & $64,10 \%$ & 79 \\
\hline 93 & Mapfre Garantias e Crédito & $63,50 \%$ & 96 \\
\hline 94 & Mitsui Sumitomo & $63,48 \%$ & 41 \\
\hline 95 & PQ & $62,40 \%$ & 85 \\
\hline 96 & Metropolitan Life & $59,96 \%$ & 26 \\
\hline 97 & Aurea & $57,94 \%$ & 82 \\
\hline 98 & Brasileira Rural & $56,81 \%$ & 99 \\
\hline 99 & Secreb & $42,05 \%$ & 97 \\
\hline 100 & Euler Hermes Crédito à Exportação & $24,30 \%$ & 100 \\
\hline
\end{tabular}

Tabela 14 - Ranking obtido com a aplicação de DEA

Conforme comparado na tabela acima, os resultados divergiram consideravelmente do ranking original. Esta divergência se dá por causa do seguinte fator. Na aplicação de Análise por Envoltória de Dados, foram considerados todos os indicadores propostos pela revista. No entanto, a participação do indicador Prêmios Ganhos com um peso bastante representativo não ocorreu na utilização do DEA. Na seleção de variáveis por Stepwise, provou-se que a presença de todas as variáveis seria a melhor opção. Assim, a participação uniforme de todas as variáveis afetou diretamente a ordenação das DMU's.

Para explicar com mais detalhes a divergência de rankings, foram escolhidas algumas DMU's para se analisar suas posições. O critério de escolha foi o seguinte: a) Selecionar as três empresas que ocupassem os primeiros lugares no ranking; b) Selecionar as três empresas que ocupassem os últimos lugares do ranking DEA, e; c) Selecionar as cinco empresas que sofreram as maiores variações de posição entre o ranking original e o resultado da aplicação da técnica DEA.

Assim, as unidades selecionadas para uma análise mais detalhada foram:

\begin{tabular}{|c|l|r|r|}
\hline Ranking DEA & \multicolumn{1}{|c|}{ Empresa } & Score DEA & Ranking Revista \\
\hline 1 & Safra Vida e Previdência & $100,00 \%$ & 58 \\
\hline 2 & Mapfre Nossa Caixa Vida e Previdência & $95,89 \%$ & 55 \\
\hline 3 & Icatu Hartford & $91,57 \%$ & 27 \\
\hline 4 & Alfa Previdência e Vida & $91,28 \%$ & 83 \\
\hline 6 & Santander Banespa & $89,69 \%$ & 76 \\
\hline 12 & Safra & $85,38 \%$ & 92 \\
\hline 37 & Bradesco Saúde & $78,11 \%$ & 1 \\
\hline 96 & Metropolitan Life & $59,96 \%$ & 26 \\
\hline 98 & Brasileira Rural & $56,81 \%$ & 99 \\
\hline 99 & Secreb & $42,05 \%$ & 97 \\
\hline 100 & Euler Hermes Crédito à Exportação & $24,30 \%$ & 100 \\
\hline
\end{tabular}

Tabela 15 - Unidades selecionadas para análise 
Observando as características pertinentes às variáveis de cada DMU’s listadas acima, padronizadas em um intervalo de zero a um, têm-se as seguintes informações:

\begin{tabular}{|c|c|c|c|c|c|c|c|c|}
\hline 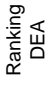 & 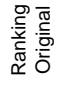 & DMU & $\begin{array}{l}\text { Prêmios } \\
\text { Ganhos }\end{array}$ & $\begin{array}{l}\text { Rentab. do } \\
\text { PL médio }\end{array}$ & $\begin{array}{c}\text { Margem } \\
\text { Operacional }\end{array}$ & Sinistralidade & $\begin{array}{l}\text { Independ. } \\
\text { Financeira }\end{array}$ & Endividamento \\
\hline 1 & 58 & Safra Vida e Previdência & 0,0172 & 0,7075 & 0,7971 & 0,4516 & 0,1593 & 0,0912 \\
\hline 3 & 27 & Icatu Hartford & 0,0819 & 0,6509 & 0,5840 & 0,5704 & 0,1064 & 0,0486 \\
\hline 4 & 83 & Alfa Previdência e Vida & 0,0035 & 0,6641 & 0,6306 & 0,4980 & 0,0001 & 0,1277 \\
\hline 6 & 76 & Santander Banespa & 0,0055 & 0,7859 & 0,8845 & 0,3909 & 0,5147 & 0,1033 \\
\hline 12 & 92 & Safra & 0,0010 & 0,7572 & 0,8243 & 0,3766 & 0,4245 & 0,2128 \\
\hline 98 & 99 & Brasileira Rural & 0,0001 & 0,7348 & 0,9056 & 0,0001 & 0,3002 & 0,5410 \\
\hline 99 & 97 & Secreb & 0,0003 & 0,5724 & 0,6838 & 0,4069 & 0,6240 & 0,1550 \\
\hline 100 & 100 & Euler Hermes Crédito à Exportação & 0,0000 & 0,5323 & 0,4315 & 0,5997 & 0,6592 & 0,1185 \\
\hline
\end{tabular}

Tabela 16 - Características das DMU's escolhidas para análise

Foi analisada cada DMU com base nos dados acima e no julgamento apresentado no método para cada indicador: a) quanto maior, melhor ou; b) quanto menor melhor. Vale ressaltar que nas situações em que os indicadores foram classificados como "quanto maior, melhor", o valor tido como ideal foi igual a 1. E nas situações em que os indicadores foram classificados como "quanto menor, melhor", o valor tido como ideal foi 0. Para facilitar o julgamento, foi calculada a mediana de cada distribuição de dados para cada variável, e chegou-se ao seguinte resultado:

\begin{tabular}{|c|c|c|c|c|c|}
\hline $\begin{array}{c}\text { Prêmios } \\
\text { Ganhos }\end{array}$ & $\begin{array}{c}\text { Rentab. do } \\
\text { PL médio }\end{array}$ & $\begin{array}{c}\text { Margem } \\
\text { Operacional }\end{array}$ & Sinistralidade & $\begin{array}{c}\text { Independ. } \\
\text { Financeira }\end{array}$ & Endividamento \\
\hline 0,0248 & 0,6342 & 0,6462 & 0,6156 & 0,3689 & 0,1520 \\
\hline
\end{tabular}

Tabela 17 - Mediana de cada indicador considerado

Com base nas medianas, classificou-se as DMU's selecionadas com base em cores, sendo o verde como fator positivo e vermelho como fator negativo. Nos três primeiros indicadores, classificados dentro do conceito de "quanto maior, melhor", todos os valores iguais ou maiores que a mediana foram classificados como bons resultados e receberam a cor verde. Os valores que ficaram abaixo da mediana foram classificados como maus resultados e receberam a cor vermelha.

Para os três últimos indicadores, classificados dentro do conceito de "quanto menor, melhor", todos os valores menores ou iguais a mediana foram classificados como bons resultados e receberam a cor verde. Os valores que ficaram acima da mediana foram classificados como maus resultados e receberam a cor vermelha. 


\begin{tabular}{|l|c|c|c|c|c|c|}
\hline \multicolumn{1}{|c|}{ DMU } & $\begin{array}{c}\text { Prêmios } \\
\text { Ganhos }\end{array}$ & $\begin{array}{c}\text { Rentab. } \\
\text { do PL } \\
\text { médio }\end{array}$ & $\begin{array}{c}\text { Marg. } \\
\text { Oper. }\end{array}$ & Sinist. & $\begin{array}{c}\text { Indep. } \\
\text { Financ. }\end{array}$ & Endiv. \\
\hline Safra Vida e Previdência & 0,0172 & 0,7075 & 0,7971 & 0,4516 & 0,1593 & 0,0912 \\
\hline $\begin{array}{l}\text { Mapfre Nossa Caixa Vida } \\
\text { e Previdência }\end{array}$ & 0,0203 & 0,7971 & 0,6887 & 0,4982 & 0,1486 & 0,1064 \\
\hline Icatu Hartford & 0,0819 & 0,6509 & 0,5840 & 0,5704 & 0,1064 & 0,0486 \\
\hline Alfa Previdência e Vida & 0,0035 & 0,6641 & 0,6306 & 0,4980 & 0,0001 & 0,1277 \\
\hline Santander Banespa & 0,0055 & 0,7859 & 0,8845 & 0,3909 & 0,5147 & 0,1033 \\
\hline Safra & 0,0010 & 0,7572 & 0,8243 & 0,3766 & 0,4245 & 0,2128 \\
\hline Bradesco Saúde & 1,0000 & 0,5129 & 0,6305 & 0,7788 & 0,3656 & 0,1520 \\
\hline Metropolitan Life & 0,0881 & 0,0001 & 0,5510 & 0,6500 & 0,1680 & 0,2158 \\
\hline Brasileira Rural & 0,0001 & 0,7348 & 0,9056 & 0,0001 & 0,3002 & 0,5410 \\
\hline Secreb & 0,0003 & 0,5724 & 0,6838 & 0,4069 & 0,6240 & 0,1550 \\
\hline $\begin{array}{l}\text { Euler Hermes Crédito à } \\
\text { Exportação }\end{array}$ & 0,0000 & 0,5323 & 0,4315 & 0,5997 & 0,6592 & 0,1185 \\
\hline
\end{tabular}

Tabela 18 - Comparação as características com as medianas das distribuições

Analisando as três primeiras posições do ranking DEA, observou-se que as empresas obtiveram um bom desempenho na maioria dos indicadores considerados. Esta estabilidade dentro dos parâmetros sugeridos pela Revista Conjuntura Econômica justifica a posição que elas ocupam no ranking gerado por meio de Análise por Envoltória de Dados. Ao se confrontar as classificações - Revista versus DEA, foi observado que a variável Prêmios Ganhos foi o principal fator classificatório no ranking da revista, enquanto a técnica DEA procurou classificar as DMU's com base no desempenho em todas as variáveis de forma equilibrada.

A DMU Safra Vida e Previdência - $1^{\circ}$ no DEA e $58^{\circ}$ na revista - não obteve um bom desempenho na variável Prêmios Ganhos. No entanto, obteve bom desempenho em todas as outras variáveis - Rentabilidade do Patrimônio Líquido, Margem Operacional, Sinistralidade, Independência Financeira e Endividamento. À este desempenho uniforme e positivo na maioria das variáveis é atribuído o primeiro lugar do ranking à esta unidade.

A empresa Mapfre Nossa Caixa Vida e Previdência - $2^{\circ}$ no DEA e $55^{\circ}$ na revista obteve um desempenho similar a empresa que ocupou o topo do ranking. No entanto, devido ao seu desempenho nas variáveis Margem Operacional, Sinistralidade e Endividamento, esta DMU ocupou o segundo lugar na classificação.

Já a DMU Icatu Hartford - $3^{\circ}$ no DEA e $27^{\circ}$ na revista - obteve bom desempenho no indicador Prêmios Ganhos. Em contrapartida, esta empresa prejudicou-se se considerar o indicador Margem Operacional. Seu desempenho nos outros indicadores foi classificado 
como positivo, com valores ficaram próximos das medianas, o que permite afirmar que esta unidade também teve um desempenho regular.

Ao analisar as DMU's que sofreram o maior deslocamento ao se comparar os rankings da revista e obtido por meio de DEA, foi observado que estas obtiveram desempenho ruim em duas ou mais variáveis.

A empresa Alfa Previdência e Vida - $4^{\circ}$ no DEA e $83^{\circ}$ na revista - obteve um desempenho ruim nos indicadores Prêmios Ganhos e Margem Operacional, dois dos três outputs considerados na análise. No entanto, nos outros quatro indicadores, esta DMU obteve um bom desempenho e conseguiu se firmar entre as primeiras colocadas. Sua escalada de posições é atribuída aos resultados nos indicadores Independência Financeira e Endividamento, bem próximos dos valores tidos como ideais (zero).

A unidade Santander Banespa - $6^{\circ}$ no DEA e $76^{\circ}$ na revista - obteve desempenho ruim nas variáveis Prêmios Ganhos e Independência Financeira, mas conseguiu obter um bom resultado em todas as outras variáveis, especialmente na variável Margem Operacional. O desempenho uniforme e positivo nas variáveis Rentabilidade do Patrimônio Líquido, Sinistralidade e Endividamento garantiu o sexto lugar para esta empresa.

A seguradora denominada Safra - $12^{\circ}$ no DEA e $92^{\circ}$ na revista - obteve desempenho ruim nas variáveis Prêmios Ganhos, Independência Financeira e Endividamento. Mas seu desempenho excelente nas variáveis Rentabilidade do Patrimônio Líquido e Margem Operacional garantiu que esta subisse várias posições no ranking obtido pelo uso da Análise por Envoltória de Dados.

Uma observação bastante interessante cabe à análise da DMU Bradesco Saúde - $37^{\circ}$ no DEA e $1^{\circ}$ na revista. Esta empresa ocupou o primeiro lugar na classificação da revista Conjuntura Econômica, mas ao ser analisada com base no resultado da Análise por Envoltória de Dados obteve desempenho desejável em todos os indicadores. Seu desempenho foi excepcional sob a perspectiva de Prêmios Ganhos. Em contrapartida, seu desempenho foi ruim em quatro das cinco variáveis restantes - Rentabilidade do Patrimônio Líquido, Margem Operacional, Sinistralidade e Endividamento. Se analisada a Independência Financeira desta unidade, observa-se que seu desempenho foi bem próximo à mediana, fato que justifica ainda mais o desempenho regular desta DMU. Assim, justifica-se de forma clara e objetiva a queda desta unidade no ranking DEA. 
A DUM Metropolitan Life - $96^{\circ}$ no DEA e $26^{\circ}$ na revista - obteve desempenho ruim em quatro das seis variáveis. Seu bom posicionamento no ranking da revista é atribuído aos seus Prêmios Ganhos. No entanto, seu desempenho péssimo na variável Rentabilidade do Patrimônio Líquido, uma variável importante para a análise, fez com que esta empresa caísse bastante ao se classificar as empresas do setor de seguros privados por meio da técnica de Análise por Envoltória de Dados.

Já as três últimas posições do ranking obtido pela técnica DEA foram bastante similares às últimas posições da revista.

A empresa Brasileira Rural - $98^{\circ}$ no DEA e $99^{\circ}$ na revista - mesmo tendo um bom desempenho em quatro das seis variáveis, ocupou um dos últimos lugares em ambos os rankings. Sua colocação ruim é atribuída ao péssimo desempenho em Prêmios Ganhos e em Endividamento, variável esta em que obteve um dos piores desempenhos dentre todas as empresas analisadas.

A DMU Secreb - $98^{\circ}$ no DEA e $99^{\circ}$ na revista - também obteve desempenho ruim em quatro das seis variáveis. A colocação ruim desta empresa foi atribuída ao desempenho desta unidade na variável Independência Financeira. A Secreb obteve o segundo mais alto valor para este indicador, enquanto seu juízo de valor se firma no conceito de "quanto menor, melhor".

Já a DMU Euler Hermes Crédito à Exportação - $100^{\circ}$ no DEA e $100^{\circ}$ na revista obteve um desempenho ruim em todos os outputs - Prêmios Ganhos, Rentabilidade do Patrimônio Líquido e Margem Operacional. Além disso, considerando a variávem Independência Financeira, essa empresa obteve o maior valor, enquanto seu juízo de valor se firma no conceito de "quanto menor, melhor". Este fato exerceu forte influência para que esta unidade ocupasse o último lugar da classificação.

A seguir estão exemplos de figuras que propõem as melhorias para cada uma das unidades analisadas anteriormente. A intenção é ilustrar como a técnica DEA, sobretudo o software Frontier Analyst, oferece a oportunidade de se identificar os benchmarks e as oportunidades de melhoria para as DMUs não eficientes em um nível de detalhe para cada variável considerada no modelo. 


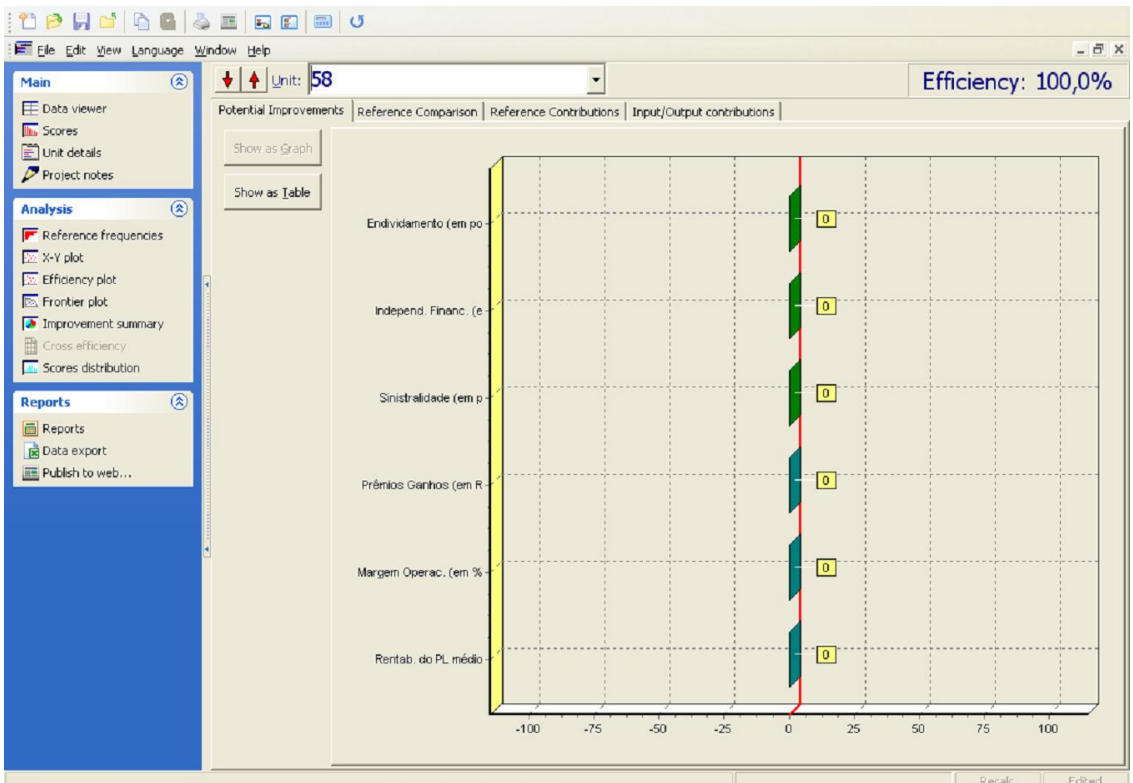

Figura 19 - Recomendações para Safra Vida e Previdência

A figura acima ilustra a situação da empresa que ocupa o primeiro lugar do ranking obtido. Analisando apenas a fronteira clássica, pode-se observar que a DMU em questão, por ocupar o topo da classificação, obteve desempenho excelente e todas as variáveis analisadas, não precisando melhorar em nenhum indicador. No entanto, ao se observar a Figura 20, podese observar que a DMU em questão necessita de ações que venham a melhorar seu desempenho nas variáveis Sinistralidade, Margem Operacional, Rentabilidade do Patrimônio Líquido e, sobretudo, na variável Prêmios Ganhos.

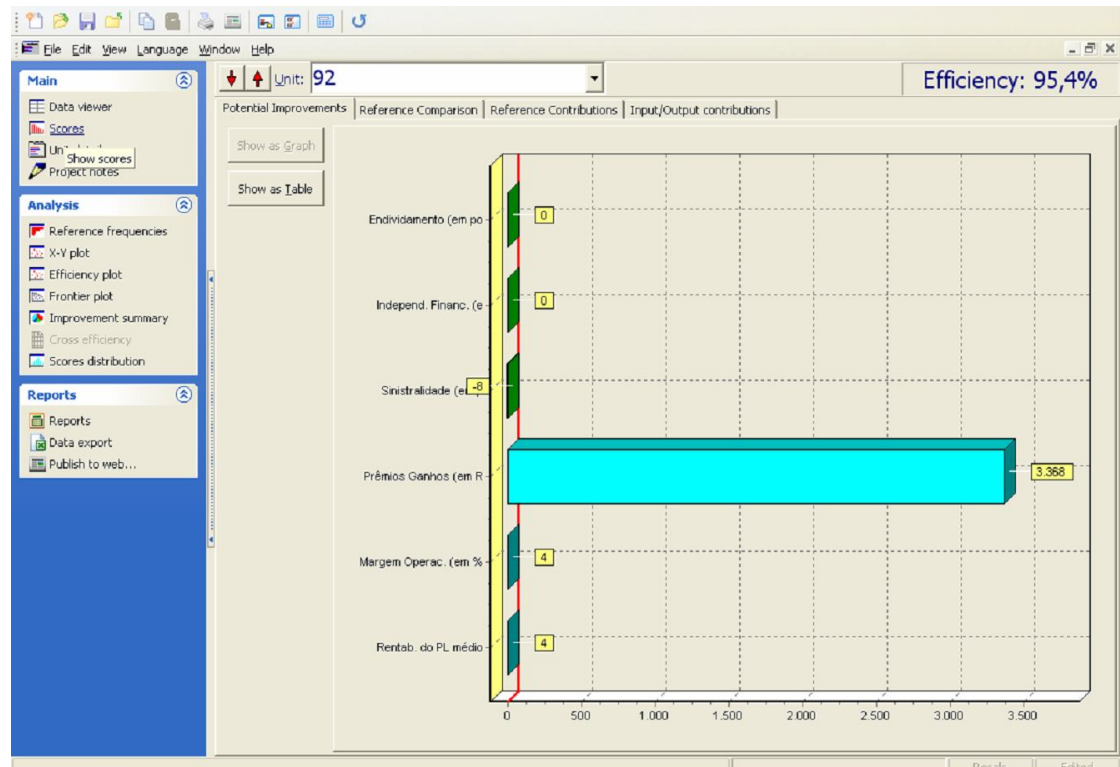

Figura 20 - Recomendações para Safra (Fronteira Clássica) 
O ranking obtido por meio da aplicação de Análise por Envoltória de Dados divergiu bastante do ranking apresentado pela Revista Conjuntura Econômica de Borges (2007). No entanto, esta divergência está bem fundamentada nos argumentos seguintes:

- O método adotado pela revista Conjuntura Econômica priorizou a classificação por Prêmios Ganhos, mesmo utilizando os outros cinco indicadores;

- A variação de indicadores e pesos atribuídos ano à ano expõe a instabilidade da metodologia utilizada;

- A técnica DEA consiste em uma técnica estruturada para avaliar eficiência de processos. Classificando as variáveis como inputs e outputs, é possível avaliar as empresas do setor de seguros privados como processadoras de atividades de negócio, alimentadas com os inputs e que geram como resultado os outputs;

- Ao avaliar o comportamento das DMU's nos indicadores, pode-se entender melhor a razão pela qual algumas empresas que ocuparam boas posições no ranking da revista caíram no ranking DEA, e vice-versa. Esse fato se dá pelo motivo de as empresas que obtiveram boa classificação no trabalho da Fundação Getúlio Vargas não possuírem um desempenho regular em todas as variáveis, fato este essencial para uma boa classificação no ranking obtido por meio da técnica DEA.

Assim, como resultado geral desta aplicação, fica a alternativa de se analisar as empresas do setor de seguros privados por um prisma diferente, utilizando uma técnica estruturada já difundida no meio acadêmico e que reduz o fator de subjetividade implícito em classificações que utilizam como método a ponderação direta.

\subsection{O ranking via Redes Neurais Artificiais}

Em sumas gerais, a aplicação de Redes Neurais artificiais obteve um resultado próximo ao ranking proposto pela revista. Porém, o objetivo inicial do trabalho é elaborar rankings por meio de duas técnicas estruturadas, e não reproduzir o ranking divulgado pela Revista Conjuntura Econômica. Portanto, a proximidade entre os resultados da técnica DEA e de RNA não representa qualidade em relação aos resultados obtidos. O que atribui respaldo aos resultados obtidos é um bom tratamento dos dados e um método bem estruturado. 
Tratando dos resultados obtidos da Rede Neural, o primeiro passo para auferir maiores conclusões foi dado com a associação de cada empresa à um neurônio. Mesmo sendo definida como parâmetro a quantidade de neurônios igual a 100, após a extração dos resultados da rede, observou-se que apenas sessenta e dois neurônios da rede foram associados ás empresas analisadas. Isso quer dizer que apenas sessenta e dois neurônios foram associados às cem empresas, indicando que pelo menos um mesmo neurônio foi associado à mais de uma empresa.

A Tabela 20 apresenta a relação entre neurônios e as empresas que compõem o banco de dados. Nessa etapa, as empresas ainda não estão ordenadas. O fato de a empresa Bradesco Seguros, de número 44 no ranking da revista, estar atribuída ao neurônio 1 não significa que esta ocupa o topo do ranking oriundo do modelo neural. Ressalva-se mais uma vez que o ranking será definido por meio do cálculo da distância euclidiana entre os neurônios.

\begin{tabular}{|c|c|c|c|c|c|}
\hline \multicolumn{2}{|r|}{ Empresa } & \multirow{2}{*}{\begin{tabular}{|c|} 
NEURÔNIO \\
1
\end{tabular}} & \multicolumn{2}{|r|}{ Empresa } & NEURÔNIO \\
\hline 44 & Bradesco Seguros & & 61 & Aliança da Bahia & 56 \\
\hline 53 & Itauseg Saúde & 1 & 65 & Sabemi & 57 \\
\hline 64 & Paraná & 1 & 47 & Zurich & 58 \\
\hline 70 & Gralha Azul & 1 & 33 & Generali & 59 \\
\hline 86 & BCS & 1 & 79 & APS & 59 \\
\hline 87 & Previmax & 1 & 41 & Mitsui Sumitomo & 60 \\
\hline 94 & Salutar Saúde & 1 & 26 & Metropolitan Life & 61 \\
\hline 4 & Sul América Saúde & 3 & 48 & Cardif & 62 \\
\hline 5 & Itaú Seguros & 3 & 45 & MetLife & 63 \\
\hline 8 & Sul América Cia. Seguro Saúde & 3 & 27 & Icatu Hartford & 66 \\
\hline 88 & Federal Vida e Previdência & 5 & 55 & Mapfre Nossa Caixa Vida e Previdência & 67 \\
\hline 89 & Java Nordeste & 5 & 58 & Safra Vida e Previdência & 67 \\
\hline 39 & Unibanco AIG Saúde & 9 & 83 & Alfa Previdência e Vida & 67 \\
\hline 95 & SBCE & 11 & 42 & Unimed & 68 \\
\hline 21 & HSBC Seguros & 13 & 23 & COSESP & 69 \\
\hline 67 & CONAPP & 13 & 19 & Marítima & 74 \\
\hline 80 & Centauro & 17 & 32 & Tokio Marine Brasil & 75 \\
\hline 74 & MBM & 18 & 69 & Excelsior & 75 \\
\hline 50 & PanAmericana & 22 & 36 & Royal \& Sunalliance & 76 \\
\hline 62 & American Life & 23 & 51 & MARES & 76 \\
\hline 34 & Unimed Saúde & 26 & 77 & Santa Catarina & 76 \\
\hline 38 & Notre Dame & 26 & 92 & Safra & 78 \\
\hline 49 & Banestes & 26 & 96 & Mapfre Garantias e Crédito & 78 \\
\hline 18 & Porto Seguro - Saúde & 27 & 99 & Brasileira Rural & 78 \\
\hline 29 & AGF Saúde & 27 & 22 & ACE & 79 \\
\hline 73 & J. Malucelli & 28 & 7 & Sul América & 80 \\
\hline 76 & Santander Banespa & 28 & 9 & Mapfre Vera Cruz & 80 \\
\hline 97 & Secreb & 29 & 11 & Tokio Marine & 80 \\
\hline 66 & AIG Brasil & 31 & 13 & AGF Brasil & 80 \\
\hline 72 & Itaú XL & 31 & 15 & Mapfre Vera Cruz Vida e Previdência & 80 \\
\hline 100 & Euler Hermes Crédito à Exportação & 32 & 12 & Caixa Seguradora & 81 \\
\hline 91 & Rural & 33 & 84 & UBF & 83 \\
\hline 93 & Kyoei & 33 & 40 & Alfa & 84 \\
\hline 68 & QBE & 34 & 28 & Minas Brasil & 85 \\
\hline 78 & Mutual & 35 & 31 & Azul & 85 \\
\hline 90 & Coface & 36 & 24 & Indiana & 86 \\
\hline 59 & Federal & 38 & 16 & Liberty & 90 \\
\hline 54 & Assurant & 40 & 14 & BrasilVeículos & 94 \\
\hline 71 & Sinaf & 43 & 10 & Aliança do Brasil & 95 \\
\hline 85 & PQ & 44 & 46 & Santander & 96 \\
\hline 37 & Yasuda & 45 & 25 & Sul América Seguros de Vida e Previdência & 97 \\
\hline 52 & Previdência do Sul & 48 & 35 & Confiança & 98 \\
\hline 81 & Gente & 49 & 57 & Nobre & 98 \\
\hline 60 & Prudential & 51 & 63 & Sulina & 98 \\
\hline 98 & AVS & 52 & 75 & Gerling Sul América & 98 \\
\hline 56 & Vida & 53 & 82 & Áurea & 98 \\
\hline 17 & HDI Seguros & 54 & 1 & Bradesco Saúde & 100 \\
\hline 20 & Chubb & 54 & 2 & Porto Seguro & 100 \\
\hline 30 & Marítima Saúde & 55 & 3 & Bradesco Auto/RE & 100 \\
\hline 43 & BrasilSaúde & 56 & 6 & Unibanco AIG & 100 \\
\hline
\end{tabular}

Tabela 19 - Associação entre empresas e neurônios 
Para ilustrar que nem todos os neurônios dentre os 100 definidos inicialmente foram considerados no modelo, pode-se observar que neurônios como o 91, 92, 03 e 99 não aparecem na tabela acima.

Todas as empresas associadas à um mesmo neurônio possuem características semelhantes. As empresas associadas ao neurônio 100, por exemplo, possuem similaridades que não estão explicitamente expostas. Para identificar essas similaridades, foi utilizado o banco de dados que serviu de input para este modelo.

Em seguida, conforme a Tabela 21, colheu-se do modelo neural a distância euclidiana entre os neurônios e o vetor representante da empresa tida como de desempenho ideal. Com base nessa distância que se deu início ao processo de ordenação propriamente dito. 


\begin{tabular}{|c|c|c|c|}
\hline Neurônio & Distância & Neurônio & Distância \\
\hline 1 & 1,397491296 & 51 & 1,532216239 \\
\hline 2 & 1,268277503 & 52 & 1,573050739 \\
\hline 3 & 1,061862647 & 53 & 1,445106075 \\
\hline 4 & 1,160201056 & 54 & 1,33043185 \\
\hline 5 & 1,313780765 & 55 & 1,388150152 \\
\hline 6 & 1,303452428 & 56 & 1,439487046 \\
\hline 7 & 1,286867928 & 57 & 1,428123767 \\
\hline 8 & 1,289242411 & 58 & 1,437001886 \\
\hline 9 & 1,290805848 & 59 & 1,505375463 \\
\hline 10 & 1,299056879 & 60 & 1,579672157 \\
\hline 11 & 1,293210962 & 61 & 1,616083797 \\
\hline 12 & 1,253978018 & 62 & 1,568269879 \\
\hline 13 & 1,251926582 & 63 & 1,48438039 \\
\hline 14 & 1,283996953 & 64 & 1,45698638 \\
\hline 15 & 1,29915802 & 65 & 1,45778633 \\
\hline 16 & 1,322220035 & 66 & 1,476887549 \\
\hline 17 & 1,339001389 & 67 & 1,476281102 \\
\hline 18 & 1,334068747 & 68 & 1,457580458 \\
\hline 19 & 1,31851941 & 69 & 1,43581233 \\
\hline 20 & 1,314620762 & 70 & 1,439912404 \\
\hline 21 & 1,290372331 & 71 & 1,447844067 \\
\hline 22 & 1,275988819 & 72 & 1,446992718 \\
\hline 23 & 1,295348754 & 73 & 1,433139728 \\
\hline 24 & 1,331628282 & 74 & 1,435529003 \\
\hline 25 & 1,348972448 & 75 & 1,464625271 \\
\hline 26 & 1,341324324 & 76 & 1,467279329 \\
\hline 27 & 1,300741288 & 77 & 1,38083955 \\
\hline 28 & 1,270090016 & 78 & 1,309279056 \\
\hline 29 & 1,279189637 & 79 & 1,30480411 \\
\hline 30 & 1,354413204 & 80 & 1,321258373 \\
\hline 31 & 1,39544494 & 81 & 1,300783418 \\
\hline 32 & 1,436088333 & 82 & 1,405119895 \\
\hline 33 & 1,469776243 & 83 & 1,508636252 \\
\hline 34 & 1,427574214 & 84 & 1,49759658 \\
\hline 35 & 1,376383384 & 85 & 1,485123871 \\
\hline 36 & 1,376238564 & 86 & 1,477942527 \\
\hline 37 & 1,385343483 & 87 & 1,444429562 \\
\hline 38 & 1,393516621 & 88 & 1,425393329 \\
\hline 39 & 1,391061915 & 89 & 1,422672648 \\
\hline 40 & 1,389128386 & 90 & 1,427295995 \\
\hline 41 & 1,3951976 & 91 & 1,425745008 \\
\hline 42 & 1,41722219 & 92 & 1,430201698 \\
\hline 43 & 1,450580477 & 93 & 1,426528156 \\
\hline 44 & 1,461286479 & 94 & 1,413172613 \\
\hline 45 & 1,435283441 & 95 & 1,447946724 \\
\hline 46 & 1,41615698 & 96 & 1,574840393 \\
\hline 47 & 1,426797449 & 97 & 1,715594741 \\
\hline 48 & 1,458993588 & 98 & 1,746574709 \\
\hline 49 & 1,471277018 & 99 & 1,442652116 \\
\hline 50 & 1,467021505 & 100 & 1,187872997 \\
\hline
\end{tabular}

Tabela 20 - Distâncias dos neur6onios em relação ao neurônio ideal

Embora nem todos os neurônios pertencentes ao modelo serem associados à empresas, foi extraído do Matlab uma matriz que calcula a distância de cada neurônio em relação ao neurônio ideal. Ressalta-se mais uma vez que o número do neurônio corresponde apenas à um 
título, com o objetivo de se tornar possível identificar os neurônios em meio à sua distribuição. $\mathrm{O}$ fato de o neurônio 1 receber este título não representa que este neurônio é o que está mais perto do neurônio ideal.

Tendo os neurônios que cada empresa se associou e a distância de cada neurônio em relação ao neurônio ideal, pode-se dar início à classificação propriamente dita. Assim, o ranking obtido por meio da aplicação de Redes Neurais Artificiais foi o seguinte:

\begin{tabular}{|c|c|c|c|c|c|c|c|}
\hline $\begin{array}{l}\text { Índice } \\
\text { Revista }\end{array}$ & Empresa & Distância & $\begin{array}{c}\text { Índice } \\
\text { RNA }\end{array}$ & $\begin{array}{l}\text { Índice } \\
\text { Revista }\end{array}$ & Empresa & Distância & $\begin{array}{c}\text { Índice } \\
\text { RNA }\end{array}$ \\
\hline 4 & Sul América Saúde & 1,06186 & 1 & 94 & Salutar Saúde & 1,39749 & 26 \\
\hline 5 & Itaú Seguros & 1,06186 & 1 & 14 & BrasilVeículos & 1,41317 & 27 \\
\hline 8 & Sul América Cia. Seg. Saúde & 1,06186 & 1 & 16 & Liberty & 1,42730 & 28 \\
\hline 1 & Bradesco Saúde & 1,18787 & 2 & 68 & QBE & 1,42757 & 29 \\
\hline 2 & Porto Seguro & 1,18787 & 2 & 65 & Sabemi & 1,42812 & 30 \\
\hline 3 & Bradesco Auto/RE & 1,18787 & 2 & 37 & Yasuda & 1,43528 & 31 \\
\hline 6 & Unibanco AIG & 1,18787 & 2 & 19 & Marítima & 1,43553 & 32 \\
\hline 21 & HSBC Seguros & 1,25193 & 3 & 23 & COSESP & 1,43581 & 33 \\
\hline 67 & CONAPP & 1,25193 & 3 & 100 & Euler Hermes C.E & 1,43609 & 34 \\
\hline 73 & J. Malucelli & 1,27009 & 4 & 47 & Zurich & 1,43700 & 35 \\
\hline 76 & Santander Banespa & 1,27009 & 4 & 43 & BrasilSaúde & 1,43949 & 36 \\
\hline 50 & PanAmericana & 1,27599 & 5 & 61 & Aliança da Bahia & 1,43949 & 36 \\
\hline 97 & Secreb & 1,27919 & 6 & 56 & Vida & 1,44511 & 37 \\
\hline 39 & Unibanco AIG Saúde & 1,29081 & 7 & 10 & Aliança do Brasil & 1,44795 & 38 \\
\hline 95 & SBCE & 1,29321 & 8 & 71 & Sinaf & 1,45058 & 39 \\
\hline 62 & American Life & 1,29535 & 9 & 42 & Unimed & 1,45758 & 40 \\
\hline 18 & Porto Seguro - Saúde & 1,30074 & 10 & 52 & Previdência do Sul & 1,45899 & 41 \\
\hline 29 & AGF Saúde & 1,30074 & 10 & 85 & $\mathrm{PQ}$ & 1,46129 & 42 \\
\hline 12 & Caixa Seguradora & 1,30078 & 11 & 32 & Tokio Marine Brasil & 1,46463 & 43 \\
\hline 22 & ACE & 1,30480 & 12 & 69 & Excelsior & 1,46463 & 43 \\
\hline 92 & Safra & 1,30928 & 13 & 36 & Royal \& Sunalliance & 1,46728 & 44 \\
\hline 96 & Mapfre Garantias e Crédito & 1,30928 & 13 & 51 & MARES & 1,46728 & 44 \\
\hline 99 & Brasileira Rural & 1,30928 & 13 & 77 & Santa Catarina & 1,46728 & 44 \\
\hline 88 & Federal Vida e Previdência & 1,31378 & 14 & 91 & Rural & 1,46978 & 45 \\
\hline 89 & Java Nordeste & 1,31378 & 14 & 93 & Kyoei & 1,46978 & 45 \\
\hline 7 & Sul América & 1,32126 & 15 & 81 & Gente & 1,47128 & 46 \\
\hline 9 & Mapfre Vera Cruz & 1,32126 & 15 & 55 & Mapfre Nossa Caixa V.P & 1,47628 & 47 \\
\hline 11 & Tokio Marine & 1,32126 & 15 & 58 & Safra Vida e Previdência & 1,47628 & 47 \\
\hline 13 & AGF Brasil & 1,32126 & 15 & 83 & Alfa Previdência e Vida & 1,47628 & 47 \\
\hline 15 & Mapfre Vera Cruz Vida e Prev. & 1,32126 & 15 & 27 & Icatu Hartford & 1,47689 & 48 \\
\hline 17 & HDI Seguros & 1,33043 & 16 & 24 & Indiana & 1,47794 & 49 \\
\hline 20 & Chubb & 1,33043 & 16 & 45 & MetLife & 1,48438 & 50 \\
\hline 74 & MBM & 1,33407 & 17 & 28 & Minas Brasil & 1,48512 & 51 \\
\hline 80 & Centauro & 1,33900 & 18 & 31 & Azul & 1,48512 & 51 \\
\hline 34 & Unimed Saúde & 1,34132 & 19 & 40 & Alfa & 1,49760 & 52 \\
\hline 38 & Notre Dame & 1,34132 & 19 & 33 & Generali & 1,50538 & 53 \\
\hline 49 & Banestes & 1,34132 & 19 & 79 & APS & 1,50538 & 53 \\
\hline 90 & Coface & 1,37624 & 20 & 84 & UBF & 1,50864 & 54 \\
\hline 78 & Mutual & 1,37638 & 21 & 60 & Prudential & 1,53222 & 55 \\
\hline 30 & Marítima Saúde & 1,38815 & 22 & 48 & Cardif & 1,56827 & 56 \\
\hline 54 & Assurant & 1,38913 & 23 & 98 & AVS & 1,57305 & 57 \\
\hline 59 & Federal & 1,39352 & 24 & 46 & Santander & 1,57484 & 58 \\
\hline 66 & AIG Brasil & 1,39544 & 25 & 41 & Mitsui Sumitomo & 1,57967 & 59 \\
\hline 72 & Itaú XL & 1,39544 & 25 & 26 & Metropolitan Life & 1,61608 & 60 \\
\hline 44 & Bradesco Seguros & 1,39749 & 26 & 25 & Sul América Seguros V.P & 1,71559 & 61 \\
\hline 53 & Itauseg Saúde & 1,39749 & 26 & 35 & Confiança & 1,74657 & 62 \\
\hline 64 & Paraná & 1,39749 & 26 & 57 & Nobre & 1,74657 & 62 \\
\hline 70 & Gralha Azul & 1,39749 & 26 & 63 & Sulina & 1,74657 & 62 \\
\hline 86 & BCS & 1,39749 & 26 & 75 & Gerling Sul América & 1,74657 & 62 \\
\hline 87 & Previmax & 1,39749 & 26 & 82 & Áurea & 1,74657 & 62 \\
\hline
\end{tabular}

Tabela 21 - Ranking obtido com a Rede Neural Artificial 
O ranking, apesar de já ordenado, apresentou uma série de empates. Estes empates se dão devido ao fato de diferentes empresas estarem associadas a um mesmo neurônio. E se a classificação é obtida por meio da distância euclidiana entre os neurônios, as empresas que estiverem associadas ao mesmo neurônio estarão a uma mesma distância do vetor da empresa fictícia tida como ideal. Assim, fez necessário adotar um critério de desempate.

Para o desempate foi considerada a ponderação sugerida pela revista. A publicação atribuiu o peso de 3,0 para a variável Prêmios Ganhos, e 2,5 para a variável Rentabilidade do Patrimônio Líquido. Todas as outras quatro variáveis não receberam ponderação, e por isso, optou-se por deixá-las fora do processo de desempate.

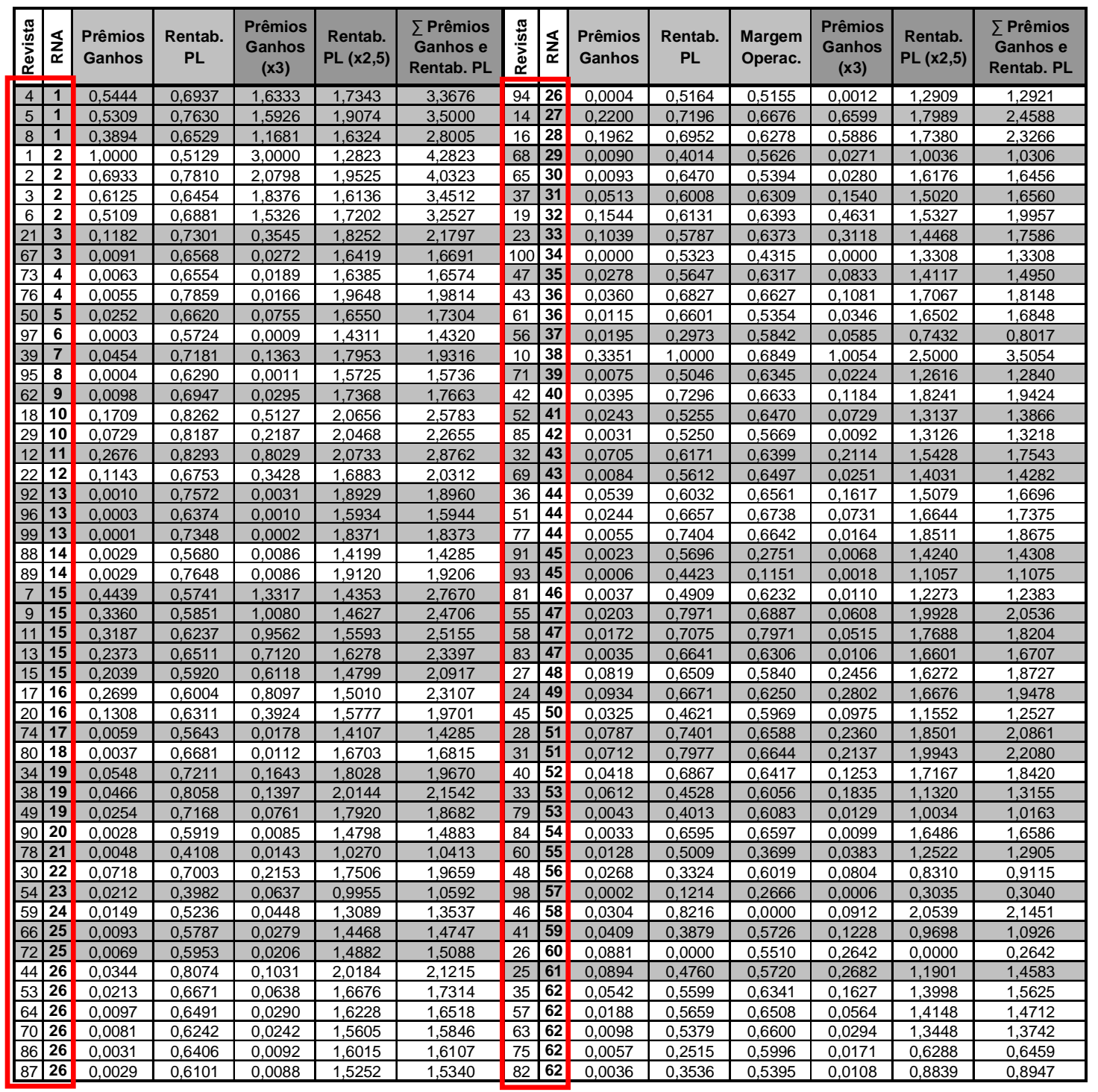

Tabela 22 - Processo de desempate entre empresas de uma mesma classe 
Para os dois indicadores escolhidos para o desempate, foram aplicadas as devidas ponderações. Conforme o juízo de valor de ambos os indicadores - "quanto maior, melhor", os pontos obtidos com a ponderação de cada variável foram somados, obtendo-se assim um total de pontos para cada empresa. Este total de pontos foi considerado o critério de desempate.

Em seguida, dentro de cada classe, ordenaram-se as empresas com base no critério de desempate. Assim, em cada classe, as empresas foram classificadas por ordem decrescente de pontos do somatório das variáveis Prêmios Ganhos e Rentabilidade do Patrimônio Líquido, com as devidas ponderações. Após este procedimento, obteve-se enfim o ranking final oriundo da aplicação de redes neurais artificiais. 


\begin{tabular}{|c|c|c|c|c|c|c|c|c|c|}
\hline 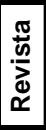 & 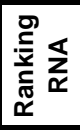 & Empresa & 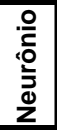 & $\begin{array}{c}\text { Coef. } \\
\text { Desemp. }\end{array}$ & 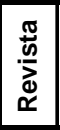 & 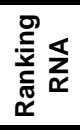 & Empresa & 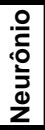 & $\begin{array}{c}\text { Coef. } \\
\text { Desemp. }\end{array}$ \\
\hline 5 & 1 & Itaú Seguros & 3 & 3,500014 & 94 & 51 & Salutar Saúde & 1 & 1,292106 \\
\hline 4 & 2 & Sul América Saúde & 3 & 3,367606 & 14 & 52 & BrasilVeículos & 94 & 2,458799 \\
\hline 8 & 3 & Sul América Cia. S.S & 3 & 2,800474 & 16 & 53 & Liberty & 90 & 2,326551 \\
\hline 1 & 4 & Bradesco Saúde & 100 & 4,282302 & 68 & 54 & QBE & 34 & 1,03063 \\
\hline 2 & 5 & Porto Seguro & 100 & 4,032326 & 65 & 55 & Sabemi & 57 & 1,645558 \\
\hline 3 & 6 & Bradesco Auto/RE & 100 & 3,451181 & 37 & 56 & Yasuda & 45 & 1,656037 \\
\hline 6 & 7 & Unibanco AIG & 100 & 3,25271 & 19 & 57 & Marítima & 74 & 1,995723 \\
\hline 21 & 8 & HSBC Seguros & 13 & 2,179705 & 23 & 58 & COSESP & 69 & 1,758623 \\
\hline 67 & 9 & CONAPP & 13 & 1,669142 & 100 & 59 & Euler Hermes C.E & 32 & 1,330803 \\
\hline 76 & 10 & Santander Banespa & 28 & 1,981397 & 47 & 60 & Zurich & 58 & 1,49498 \\
\hline 73 & 11 & J. Malucelli & 28 & 1,657383 & 43 & 61 & BrasilSaúde & 56 & 1,814798 \\
\hline 50 & 12 & PanAmericana & 22 & 1,730444 & 61 & 62 & Aliança da Bahia & 56 & 1,684828 \\
\hline 97 & 13 & Secreb & 29 & 1,431984 & 56 & 63 & Vida & 53 & 0,801726 \\
\hline 39 & 14 & Unibanco AIG Saúde & 9 & 1,931574 & 10 & 64 & Aliança do Brasil & 95 & 3,505377 \\
\hline 95 & 15 & SBCE & 11 & 1,573616 & 71 & 65 & Sinaf & 43 & 1,284031 \\
\hline 62 & 16 & American Life & 23 & 1,766303 & 42 & 66 & Unimed & 68 & 1,942407 \\
\hline 18 & 17 & Porto Seguro - Saúde & 27 & 2,578327 & 52 & 67 & Previdência do Sul & 48 & 1,386628 \\
\hline 29 & 18 & AGF Saúde & 27 & 2,265488 & 85 & 68 & PQ & 44 & 1,321811 \\
\hline 12 & 19 & Caixa Seguradora & 81 & 2,876212 & 32 & 69 & Tokio Marine Brasil & 75 & 1,754275 \\
\hline 22 & 20 & ACE & 79 & 2,031173 & 69 & 70 & Excelsior & 75 & 1,428187 \\
\hline 92 & 21 & Safra & 78 & 1,896004 & 77 & 71 & Santa Catarina & 76 & 1,867484 \\
\hline 99 & 22 & Brasileira Rural & 78 & 1,837322 & 51 & 72 & MARES & 76 & 1,737454 \\
\hline 96 & 23 & Mapfre Garantias e Crédito & 78 & 1,594423 & 36 & 73 & Royal \& Sunalliance & 76 & 1,669608 \\
\hline 89 & 24 & Java Nordeste & 5 & 1,920603 & 91 & 74 & Rural & 33 & 1,430805 \\
\hline 88 & 25 & Federal Vida e Previdência & 5 & 1,428532 & 93 & 75 & Kyoei & 33 & 1,107514 \\
\hline 7 & 26 & Sul América & 80 & 2,76696 & 81 & 76 & Gente & 49 & 1,238325 \\
\hline 11 & 27 & Tokio Marine & 80 & 2,515512 & 55 & 77 & Mapfre Nossa Caixa V.P & 67 & 2,053586 \\
\hline 9 & 28 & Mapfre Vera Cruz & 80 & 2,470647 & 58 & 78 & Safra Vida e Previdência & 67 & 1,820389 \\
\hline 13 & 29 & AGF Brasil & 80 & 2,339703 & 83 & 79 & Alfa Previdência e Vida & 67 & 1,670718 \\
\hline 15 & 30 & Mapfre Vera Cruz V.P. & 80 & 2,091743 & 27 & 80 & Icatu Hartford & 66 & 1,872749 \\
\hline 17 & 31 & HDI Seguros & 54 & 2,310748 & 24 & 81 & Indiana & 86 & 1,947838 \\
\hline 20 & 32 & Chubb & 54 & 1,97011 & 45 & 82 & MetLife & 63 & 1,252687 \\
\hline 74 & 33 & MBM & 18 & 1,428513 & 31 & 83 & Azul & 85 & 2,207986 \\
\hline 80 & 34 & Centauro & 17 & 1,681463 & 28 & 84 & Minas Brasil & 85 & 2,086131 \\
\hline 38 & 35 & Notre Dame & 26 & 2,15416 & 40 & 85 & Alfa & 84 & 1,841989 \\
\hline 34 & 36 & Unimed Saúde & 26 & 1,96704 & 33 & 86 & Generali & 59 & 1,315522 \\
\hline 49 & 37 & Banestes & 26 & 1,86817 & 79 & 87 & APS & 59 & 1,016306 \\
\hline 90 & 38 & Coface & 36 & 1,48825 & 84 & 88 & UBF & 83 & 1,65855 \\
\hline 78 & 39 & Mutual & 35 & 1,041251 & 60 & 89 & Prudential & 51 & 1,290534 \\
\hline 30 & 40 & Marítima Saúde & 55 & 1,965946 & 48 & 90 & Cardif & 62 & 0,911473 \\
\hline 54 & 41 & Assurant & 40 & 1,059165 & 98 & 91 & AVS & 52 & 0,304025 \\
\hline 59 & 42 & Federal & 38 & 1,353723 & 46 & 92 & Santander & 96 & 2,145136 \\
\hline 72 & 43 & Itaú XL & 31 & 1,508758 & 41 & 93 & Mitsui Sumitomo & 60 & 1,09265 \\
\hline 66 & 44 & AIG Brasil & 31 & 1,474676 & 26 & 94 & Metropolitan Life & 61 & 0,264205 \\
\hline 44 & 45 & Bradesco Seguros & 1 & 2,121547 & 25 & 95 & Sul América Seguros V.P. & 97 & 1,458268 \\
\hline 53 & 46 & Itauseg Saúde & 1 & 1,731409 & 35 & 96 & Confiança & 98 & 1,562511 \\
\hline 64 & 47 & Paraná & 1 & 1,651774 & 57 & 97 & Nobre & 98 & 1,471186 \\
\hline 86 & 48 & BCS & 1 & 1,610707 & 63 & 98 & Sulina & 98 & 1,374173 \\
\hline 70 & 49 & Gralha Azul & 1 & 1,584646 & 82 & 99 & Áurea & 98 & 0,894733 \\
\hline 87 & 50 & Previmax & 1 & 1,533954 & 75 & 100 & Gerling Sul América & 98 & 0,645913 \\
\hline
\end{tabular}

Tabela 23 - Ranking obtido com RNA após desempate

Só então após o desempate, foi estabelecida a real classificação por meio de Redes Neurais artificiais. As cem empresas componentes do banco de dados foram organizadas primeiramente pelo cálculo da distância euclidiana entre os neurônios a que estas se associaram e o neurônio fictício criado com base em características de uma empresa com desempenho perfeito em todos os indicadores. Em seguida, dentre de cada classe, foi 
realizado o desempate. Este processo como um todo fundamenta e justifica o uso de Redes neurais Artificiais, em especial a arquitetura de Mapas Auto-Organizáveis de Kohonen, para classificar empresas de um mesmo setor.

Ao se separar as empresas com base nos neurônios a que estas se associaram, separam-se as empresas com base em características em comum. Assim, dentro de cada classe, fica mais justo utilizar critérios como a utilização de pesos e julgamentos de ordem de grandezas.

Como última análise realizada e que forneceu resultados representativos, foi avaliado o desempenho de alguns neurônios dentro de cada um dos indicadores. Sendo a classificação das empresas fortemente influenciada pelo neurônio a que estas se associaram, foi avaliado o desempenho do neurônio dentro de cada variável considerando os valores máximos e mínimos obtidos, e também o juízo de valor - "quanto maior/menor, melhor". O critério de escolha dos neurônios a serem analisados foi definido com base na quantidade de empresas que se associaram à eles.

O primeiro neurônio analisado foi o neurônio três, que teve as empresas Itaú Seguros, Sul América Saúde e Sul América Cia. Seguro Saúde, as três primeiras colocadas do ranking.

\begin{tabular}{|c|c|c|c|c|c|c|}
\hline Neurônio & PG & RENTAB & MO & SINIST & IF & ENDIV \\
\hline 3 & 0,446975 & 0,672564 & 0,602746 & 0,699155 & 0,663328 & 0,08779 \\
\hline Máximo: & 0,643445 & 0,80677 & 0,94271 & 0,778936 & 0,833454 & 0,741124 \\
\hline Mínimo: & 0,003304 & 0,316236 & 0,098148 & 0,277193 & 0,343646 & 0,015334 \\
\hline mediana: & 0,042198 & 0,599975 & 0,377708 & $\overline{0,638778}$ & 0,635985 & 0,145949 \\
\hline
\end{tabular}

Figura 21 - Características do neurônio 3, máximo, mínimo e mediana das séries.

As empresas que se associaram a este neurônio obtiveram, de uma forma geral, um bom desempenho nas variáveis Prêmios Ganhos, Rentabilidade do Patrimônio Líquido e Margem Operacional, devido ao resultado acima da mediana e bem próximo ao valor máximo obtido nestas três distribuições. Já nas variáveis Sinistralidade e Independência Financeira não apresentaram um bom resultado, ficando acima da mediana, e distantes do valor mínimo em cada distribuição. Finalmente, na variável Endividamento, o neurônio 3 realizou um bom desempenho, ficando abaixo da mediana e bem próximo ao valor mínimo. Assim, pode-se afirmar que as empresas associadas a este neurônio tiveram como diagnóstico de seu desempenho, o mesmo diagnóstico atribuído ao neurônio. 
Outro neurônio analisado foi o neurônio 100. A este, se associaram quatro empresas Bradesco Saúde, Porto Seguro, Bradesco Auto/RE e Unibanco AIG.

\begin{tabular}{|c|c|c|c|c|c|c|}
\hline Neurônio & PG & RENTAB & MO & SINIST & IF & ENDIV \\
\hline 100 & 0,643445 & 0,64338 & 0,267805 & 0,641862 & 0,640019 & 0,275705 \\
\hline Máximo: & 0,643445 & 0,80677 & 0,94271 & 0,778936 & 0,833454 & 0,741124 \\
\hline Mínimo: & 0,003304 & 0,316236 & 0,098148 & 0,277193 & 0,343646 & 0,015334 \\
\hline mediana: & 0,042198 & 0,599975 & 0,377708 & 0,638778 & 0,635985 & 0,145949 \\
\hline
\end{tabular}

Figura 22 - Características do neurônio 100, máximo, mínimo e mediana das séries

O neurônio 100 exerceu um desempenho excelente nas variáveis Prêmios Ganhos e Rentabilidade do Patrimônio Líquido, ditando inclusive o máximo valor obtido na distribuição de valores do indicador Prêmios Ganhos. O indicador Margem Operacional apresentou desempenho abaixo da mediana e bastante distante do valor máximo da distribuição, julgado assim como um resultado ruim. Nos indicadores Sinistralidade e Independência Financeira, o desempenho deste neurônio foi mediano, obtendo valores bem próximos da mediana. Por último, o indicador Endividamento obteve um resultado ruim, ficando acima da mediana e distante do valor mínimo da distribuição, considerando que este indicador possui a orientação de "quanto menor, melhor".

O neurônio 80 obteve cinco empresas associadas a si. Foram elas Sul América, Tókio Marine, Mapfre Vera Cruz, AGF Brasil e Mapfre Vera Cruz Vida e Previdência.

\begin{tabular}{|c|c|c|c|c|c|c|}
\hline Neurônio & PG & RENTAB & MO & SINIST & IF & ENDIV \\
\hline 80 & 0,255304 & 0,594406 & 0,270087 & 0,639749 & 0,64596 & 0,223459 \\
\hline Máximo: & 0,643445 & 0,80677 & 0,94271 & 0,778936 & 0,833454 & 0,741124 \\
\hline Mínimo: & 0,003304 & 0,316236 & 0,098148 & 0,277193 & 0,343646 & 0,015334 \\
\hline mediana: & 0,042198 & 0,599975 & 0,377708 & 0,638778 & 0,635985 & 0,145949 \\
\hline
\end{tabular}

Figura 23 - Características do neurônio 80, máximo, mínimo e mediana das séries

A unidade de processamento 80 obteve desempenho à desejar nas variáveis Prêmios Ganhos e Margem Operacional - "quanto maior, melhor", devido à um resultado abaixo da mediana e bem distante dos valores máximos das distribuições. Nos indicadores Rentabilidade do Patrimônio Líquido, Sinistralidade e Independência Financeira, este neurônio obteve bom desempenho, devido à proximidade de seus valores às medianas de cada indicador. Já o desempenho na variável Endividamento não foi satisfatório, ficando acima da mediana, mas manteve-se relativamente próximo do valor ideal - mínimo. 
O penúltimo neurônio analisado foi o neurônio 1. A este se associaram as empresas Bradesco Seguros, Itauseg Saúde, Paraná, BCS, Gralha Azul, Previmax e Salutar Saúde.

\begin{tabular}{|c|c|c|c|c|c|c|}
\hline Neurônio & $\overline{P G}$ & RENTAB & MO & SINIST & IF & ENDIV \\
\hline 1 & 0,011929 & 0,80677 & 0,94271 & 0,645068 & 0,556912 & 0,015334 \\
\hline Máximo: & 0,643445 & 0,80677 & 0,94271 & 0,778936 & 0,833454 & 0,741124 \\
\hline Mínimo: & 0,003304 & 0,316236 & 0,098148 & 0,277193 & 0,343646 & 0,015334 \\
\hline mediana: & 0,042198 & 0,599975 & $\overline{0,377708}$ & 0,638778 & 0,635985 & 0,145949 \\
\hline
\end{tabular}

Figura 24 - Características do neurônio 1, máximo, mínimo e mediana das séries

As empresas que se associaram a este neurônio tiveram um desempenho ruim ao analisar-se a variável Prêmios Ganhos, ficando abaixo da mediana e muito distantes do valor máximo obtido na distribuição. No entanto, este neurônio ditou os valores-referência para outros três indicadores: Rentabilidade do Patrimônio Líquido (máximo), Margem Operacional (máximo) e Endividamento (mínimo). As variáveis Sinistralidade e Independência Financeira obtiveram desempenhos ruins, mas ainda assim com valores próximos à mediana.

Finalmente, o último neurônio a ser analisado foi o de número 98. A este se associaram as empresas Confiança, Nobre, Sulina, Áurea e Gerling Sul América.

\begin{tabular}{|c|c|c|c|c|c|c|}
\hline Neurônio & $\overline{P G}$ & RENTAB & MO & SINIST & IF & ENDIV \\
\hline 98 & 0,027008 & 0,608999 & 0,141177 & 0,464652 & 0,600636 & 0,741124 \\
\hline Máximo: & 0,643445 & 0,80677 & 0,94271 & 0,778936 & 0,833454 & 0,741124 \\
\hline Mínimo: & 0,003304 & 0,316236 & 0,098148 & 0,277193 & 0,343646 & 0,015334 \\
\hline mediana: & 0,042198 & 0,599975 & 0,377708 & 0,638778 & 0,635985 & 0,145949 \\
\hline
\end{tabular}

Figura 25 - Características do neurônio 1, máximo, mínimo e mediana das séries

As empresas que se associaram à este neurônio obtiveram desempenho ruim nos indicadores Prêmios Ganhos, Margem Operacional e Endividamento. No indicador Prêmios Ganhos, este neurônio manteve-se bastante abaixo da mediana e distante do valor-referência máximo, devido ao julgamento "quanto maior, melhor". A variável Margem Operacional obteve o mesmo diagnóstico que a variável Prêmios Ganhos. Já o indicador Endividamento desempenhou um papel que o colocou em um patamar superior à mediana, ficando também distante do valor-referência - mínimo, devido ao julgamento "quanto menor, melhor". O indicador Patrimônio Líquido obteve valor levemente superior à mediana, atendendo às orientações que lhe foram atribuídas. Já os indicadores Sinistralidade e Independência Financeira ficaram abaixo da mediana, e não muito distantes dos valores mínimos, tidos como referência de desempenho para estes. 
Com o objetivo de ilustrar a forma como as empresas estão dispostas no espaço, foram retiradas do Matlab as seguintes figuras:

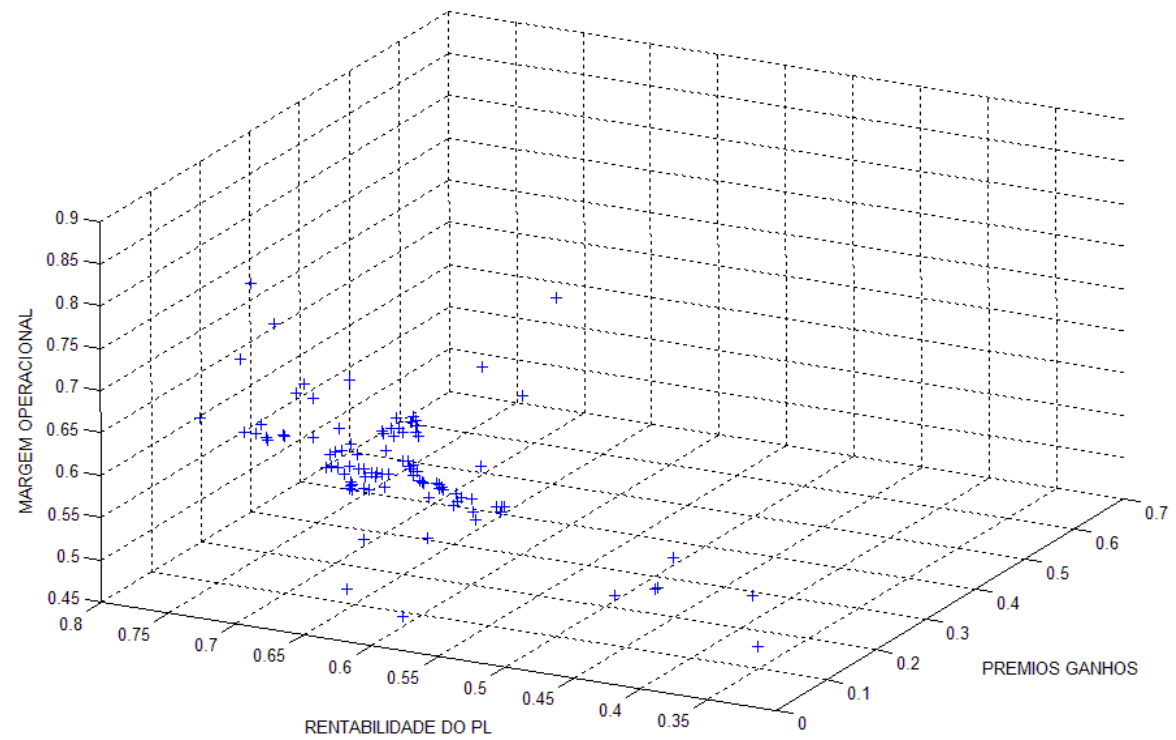

Figura 26 - Distribuição das empresas no espaço

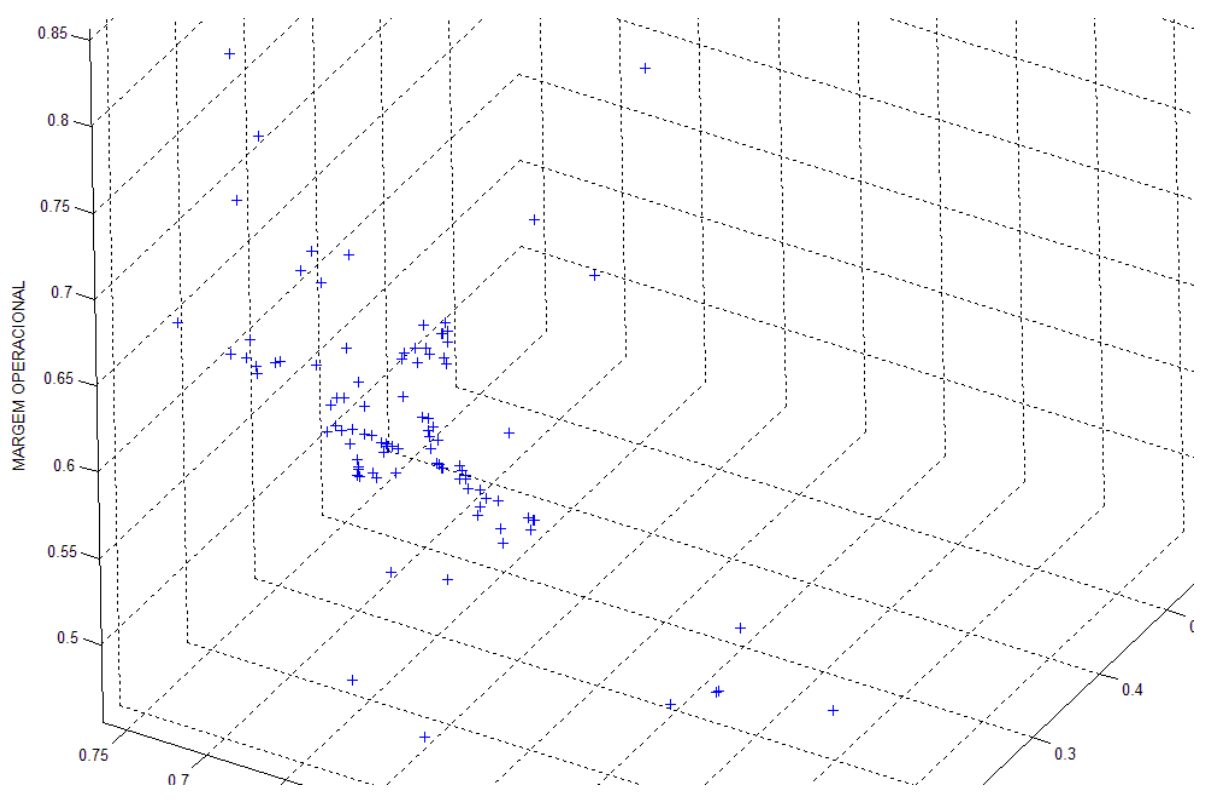

Figura 27 - Distribuição das empresas no espaço (2x) 


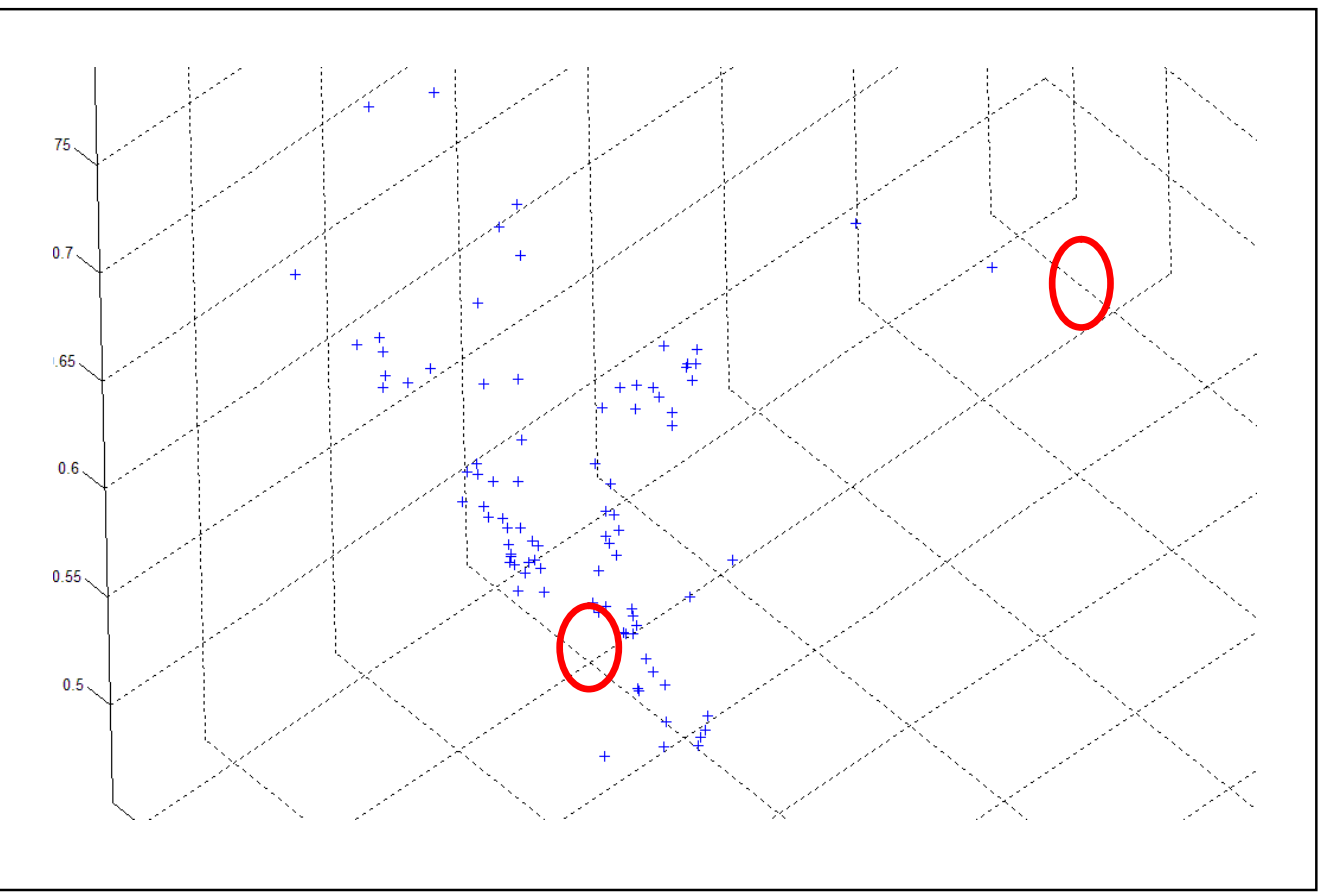

Figura 28 - Empresas com características distintas

Pode-se observar que as figuras acima respaldam ainda mais a proposta de se identificar empresas com características em comum, e só então classificá-las por ordem de desempenho. As empresas sinalizadas com um círculo na Figura 16 são diferentes demais para serem comparadas da mesma forma.

Finalizando essa seção, levanta-se um ponto bastante importante desta pesquisa. Em diversas publicações (HAYKIN, 2001; HUARNG e YU, 2006; LEUNG, 2004) atribuem às redes neurais o conceito de uma técnica em que se tem dificuldade de entender a forma como o neurônio computacional exerce sua função. E, de fato, a técnica de geração de modelos neurais não representa uma técnica de simples compreensão. No entanto, como ponto forte desta pesquisa, ressalta-se o procedimento de procurar nos neurônios as características que foram utilizadas para classificar as empresas do setor de seguros privados. A partir desta iniciativa, pode-se penetrar um pouco mais no resultado gerado pela Rede Neural e entender como que os neurônios se comportam quando comparados ao vetor fictício tido como ideal, além de identificar a razão pela qual as empresas se associaram a determinados neurônios. 


\section{CONCLUSÕES E CONSIDERAÇÕES FINAIS}

Nos dias de hoje se faz necessário que métodos quantitativos sejam utilizados com maior freqüência, objetivando uma sólida fundamentação de problemas e de suas respectivas soluções, assim como a validação ou descarte de hipóteses, e a realização de análises estatísticas voltadas para áreas não ligadas às ciências quantitativas como matemática, estatística e física.

O setor de seguros pode ser considerado um setor bastante volátil. As empresas seguradoras, regidas por diversas regulamentações de caráter social e econômico, e tendo o investimento de reservas no mercado financeiro como principal fonte para geração e alavancagem de capital, encontram-se em uma situação delicada, porém favorável. A criação de produtos destinados aos mais variados segmentos de renda, o aumento nas vendas de produtos como o seguro-saúde e automóvel, e a quebra do monopólio do resseguro fazem com que o setor de seguros incremente sua abrangência e venha a diversificar sua atuação, dando solidez e perspectiva de crescimento àqueles que nele se encaixam de alguma forma.

Se comparadas entre si, as duas técnicas possuem algumas particularidades. Mas vale ressaltar o grau de complexidade em afirmar qual dos rankings - revista, DEA e RNA, obteve o melhor resultado. E, de fato, nem é este o objetivo da pesquisa. Dentro de cada metodologia, os rankings apresentaram pontos positivos e negativos. Na busca por fatos que explicassem os resultados, a pesquisa conseguiu apresentar informações que embasassem a razão pelo qual as empresas ocuparam as devidas colocações.

Ao analisar a aplicação da técnica de Análise por Envoltória de Dados, esta se mostrou bastante aplicável, quando comparada à técnica de Redes Neurais Artificiais, uma vez considerado os parâmetros dificuldade de aplicação, tempo de processamento e divergência nos resultados. O passo que torna a análise por DEA um pouco mais difícil de aplicar é o procedimento para seleção de variáveis Stepwise, mas que mesmo assim, não possui um elevado grau de complexidade. Um fato importante na aplicação da técnica DEA é o conhecimento sobre as variáveis que estão sendo utilizadas no modelo, pois o julgamento do que serão inputs e o que serão outputs faz uma diferença significativa nos resultados da 
aplicação.

Já a técnica de Redes Neurais artificiais se mostrou pouco aplicável em situações que necessitam de agilidade para obtenção de resultados. Além do fato de o software Matlab possuir uma interface menos amigável que o software Frontier Analyst, esta técnica exige um conhecimento matemático considerável. E, mesmo se utilizando as tool boxes deste sistema, que seriam as caixas de ferramentas de outros aplicativos difundidos mundo a fora, se faz necessário o conhecimento de linguagens de programação.

Em relação ao processamento computacional, a técnica de RNA também exige um tempo de processamento maior. Mesmo estando o tempo de processamento diretamente ligado ao número de iterações considerado no modelo, na aplicação realizada, o modelo só apresentou resultados plausíveis ao receber o comando de operar com nove mil iterações, um número considerado elevado diante do montante de dados considerados.

Analisando o método proposto pela revista, chega-se a conclusão de que este representa opção plausível, de acordo com o fim que a pesquisa possui. Obviamente, consiste em um método simples e de aplicabilidade viável. Mas apresenta lacunas para questionamentos, como a questão de o ranking obtido pelo método da revista considerando todas as variáveis sugeridas ser praticamente igual ao ranking quando ordenadas as empresas por ordem do indicador Prêmios Ganhos. Além disso, observou-se que as empresas que ocuparam os primeiros lugares no ranking da revista não obtiveram bons resultados na maioria das variáveis analisadas.

Portanto, considerando os pontos positivos e negativos de cada um dos três rankings, o trabalho considerou como a opção o ranking oriundo da Rede Neural Artificial como o mais adequado para classificar as empresas do setor de seguros privados. Com uma combinação que equilibra reduzido grau de aplicabilidade, a classificação por grupos de empresas com características semelhantes e com um resultado que ordenou as empresas por desempenho equilibrado em todas as variáveis, o ranking por RNA apresentou resultados que justificam de forma mais justa o desempenho das empresas consideradas.

Para pesquisas futuras, fica a oportunidade de explorar mais o estereótipo dado à técnica de Redes Neurais Artificiais como modelos de difícil aplicação e entendimento. Este estigma percorre as aplicações de RNA por vários campos e representa uma grande dificuldade em se validar aplicações por meio desta técnica. Em contrapartida, nos campos 
ocupados pela Engenharia de Produção, a aplicação de redes neurais ainda possui território para ser alcançado. 


\section{REFERÊNCIAS BIBLIOGRÁFICAS}

ABBOTT, M.; DOUCOULIAGOS, C. The efficiency of Australian universities: a data envelopment analysis. In: Economics of Education Review, v. 22, p. 89-97, 2003. Administracion Portuaria del Uruguay. Disponível em: http://www.globalmvd.com.uy.

ALLEN, F. T. Principios generales de seguros. Mexico: Fondo de Cultura, 1949.

ALMEIDA, M. R.; REBELATTO, D. A. N. Eficiência das Infra-estruturas Produtivas: uma sistematização na seleção das variáveis. In: XXXIX Simpósio Brasileiro de Pesquisa Operacional 2007. Fortaleza, 2007.

ALMEIDA, M. R.; REBELATTO, D. N. Métodos para avaliar investimentos em infraestrutura. In: Encontro Nacional de Engenharia de Produção 2007. Foz do Iguaçu, 2007.

ALMEIDA, M. R; MARIANO E. B.; REBELATTO, D. A. N. Análise de eficiência dos aeroportos internacionais brasileiros. In: XXVII Encontro Nacional de Engenharia de Produção. Foz do Iguaçu, 2007.

ANDREOU, P. C.; CHARAlambOUS, C.; MARTZOUKOS, S. H. (2006). Pricing and trading European options by combining artificial neural networks and parametric models with implied parameters. European Journal of Operational Research.

BANA E COSTA, C. A. Metodologia Multicritério de Apoio à Decisão: A Abordagem Macbeth. Lisboa: UFPE, 2003.

BANA E COSTA, C. A.; CHAGAS, M. P. A career choice problem: An example of how to use MACBETH to build a quantitative value model based on qualitative value judgments. European Journal of Operational Research, v. 153, p. 323-331, 2004.

BANA e COSTA, C. A.; VANSNICK, J. C. Uma nova abordagem ao problema da construção de uma função de valor cardinal: MACBETH. In: Investigação Operacional 15. p. 15-35.

BANA e COSTA, C.A. (1995a). Processo de apoio à decisão: problemáticas, actores e acções. In: Apostila do curso metodologias multicritérios de apoio à decisão- ENE/UFSC. Florianópolis.

BANA e COSTA, C.A. (1995b). O que entender por tomada de decisão multicritério ou multiobjectivo? In: Apostila do Curso Metodologias Multicritérios de Apoio à Decisão ENE/UFSC. Florianópolis: 1995. 
BANKER, R. D.; CHARNES, A.; COOPER, W. W. Some models for estimating technical and scale inefficiencies in data envelopment analysis. Management Science, v. 30, p. 1078$1092,1984$.

BARRETO, J. M. Inteligência Artificial: No limiar do século XXI. Duplic Edições, 1997.

BECK, T.; LEVINE, R.; LOAYZA, N. Finance and the Sources of Growth. Journal of Financial Economics, v. 58(1-2), p. 261-300, 2000.

BECK, T.; WEBB, I. Economic Demographic, and Institutional Determinants of Life Insurance Consumption Across Countries. World Bank Economic Review, v. 17(1), p. 51-88, 2003.

BELTON, V.; STEWART. T. J. Multiple Criteria Decision Analysis: an integrated approach. In: Academic Publishers, 2002.

BERGENDAHL, G. DEA and benchmarks - an application to Nordic banks. Annals of Operations Research. v. 82, p. 233-249, 1998.

BIALOSKORSKI NETO, Sigismundo; NAGANO, M. S.; MORAES, Marcelo Botelho da Costa. Utilização de Redes Neurais Artificiais para Avaliação Sócio-Econômica: Uma Aplicação em Cooperativas. Revista de Administração (USP), São Paulo, v. 41, n. 1, p. 59-68, 2006.

BISHOP, C. M. Neural Networks for pattern recognition. Birmingham: Oxford University Press, 1995.

BLACK, K. J.; SKIPPER, H. J. Life and Health Insurance (Thirteenth Edition). Upper Saddlle River. New Jersey: Prentice-Hall, 2000.

BODYANSKIY, Y.; POPOV, S. Neural network approach to forecasting of quasiperiodic financial time series. European Journal of Operational Research, v. 175, Issue 3, p. 1357 1366, 2006.

BOGARDI, J. J.; NACHTNEBEL, H. Multicriteria decision analysis in warer resources management. UNESCO, 1994.

BORGES, E. De cara nova. Revista Conjuntura Econômica, v. 61, n. 05, 2007.

BOUYSSOU, B. Building criteria: a prerequisite for MCDA. In: BANA E COSTA C.A. (Org.). Readings in Multiple Criteria Decision Aid. 1990. p. 58-80.

BOUYSSOU, D. Décision multicritèrie ou aide multicritèrie? In:Bulletin du Groupe de Travail Européen “Aide Multicritèrie à la Décision”. Series 2, n. 2, 1993.

BRAGA, A. P.; LUDERMIR, T. B.; CARVALHO, A.C.P.L. F. Redes Neurais Artificiais: teoria e aplicações. Rio de Janeiro: Livro Técnico e Científico, 2000.

BROCKETT, P. L.; XIA, X.; DERRIG, R. A. Using Konen's Self Organized Feature Map to uncover automobile bodily injury claims fraud. The Journal of Risk and Insurance, v.65 (2), p. 245-274, 1998. 
BROWNE, M. J.; CHUNG, J.; FREES, E.W. International Property-Liability Insurance Consumption. Journal of Risk and Insurance, v. 67(1), p. 73-90, 2000.

BUENO, D. Imagem transparente para crescer e lucrar. Revista Conjuntura Econômica. Maio, p. 22-26, 2005.

BUTTON,K.J.; WEYMAN-JONES, T. G. Ownership Structure, Institucional Organizational and Measured X-Efficiency. American Economic Review, v. 82, n. 2, p. 439-444, 1992.

CAIANIELLO, E. R. Outline of a theory of thought-processes and thinking machines. Journal of Theoretical Biology, v. 2, p. 204-235, 1961.

CALOGHIROU, Y.; DIAKOULAKI, D.; TSAKANIKAS, A. A multicriteria DSS for the dynamic assessment of corporate and sectoral performance. European Symposium on Intelligent Techniques. 1999.

CARPENTER, G., GROSSBERG, S. A massively parallel architecture for a self-organizing neural pattern recognition machine. Computer Vision, Graphics and Image Processing, v. 37. 1987. p. 54-115.

CARSON, J. M. The editor's corner. Journal of Insurance Issues. Northridge, v. 25, n. 1, 2002.

CARUANA, R., BALUJA, S., MITCHELL, T. M. (1995). Using the future to sort out the present. Neural Information Processing Systems (NIPS' 1995). Denver, USA: MIT Press, 1995. p. 959-965.

CASA NOVA, S.P.C. Utilização da Análise por Envoltória de Dados (DEA) na análise de demonstrações contábeis. Tese de Doutorado. Universidade de São Paulo, São Paulo, 2002.

CAVES D. W.; CHRISTENSEN L. R.; DIEWERT W. E. The economic theory of index numbers and the measurement of input, output and productivity. Econometrica, v. 50, n.6, p.1393-1414, 1982.

CERVO, A.L; BERVIAN, P. A. Metodologia Científica. São Paulo: Markron, 1983.

CHAKRABORTY, K.; MEHROTRA, K.; MOHAN, C. K.; RANKA, S. Forecasting the behavior of multivariate time series using neural networks. Neural Networks, v.5, Issue 6, p. 961-970, 1992.

CHARNES, A.; COOPER, W. W.; RHODES, E. Data Envelopment Analysis: theory, methodology and applications. 2 ed. Norvell: Kluwer Academic Press, 1996.

CHARNES, A.; COOPER, W. W.; RHODES, E. Measuring efficiency of decision making units. European Journal of Operational Research, v. 1, p. 429-444, 1978.

CHARNES, A.; COOPER, W.W. Preface to topics in Data Envelopment Analysis. Annals of Operations Research. v.2, p.59-94, 1985.

CHESTER, M. Neural Networks: A Tutorial. Prentice Hall. 1993. 
CHIRIKOS, T. N.; SEAR, A. M. Measuring hospital efficiency: a comparison of two approaches. Health Services Research, v. 34, p.1389-1408, 2000.

$\mathrm{CHO}, \mathrm{K}$; CHO, Y. A loss function approach to group preference aggregation in the AHP. International Symposium on the Analytic Hierarchy Process. 2003.

CLIVILLE, V.; BERRAH, L.; MAURIS, G. Quantitative expression and aggregation of performance measurements based on the MACBETH multi-criteria method. Int. J. Production Economics, v. 105, p. 171-189, 2007.

COELLI, T.; PRAZADA RAO D. S.; BATTESE G. E. An introduction to efficience and productivity analysis. Massachussets Kluer Academic Pulishers. 1998.

COHEN, W. W., SCHAPIRE, R. E., SINGER, Y. Learning to order things. Journal of Artificial Inteligence Research. (JAIR), p.10:243-2701999.

COOPER, W.; SIEFORD, L.; TONE, K. Date Envelopment Analysis. A Comprehensive Text with Models, Applications, Reference and DEA-Solver software. Kluwer Academic Publishers, Norwell. 2000.

COPELAND, T., KOLLER, T., MURRIN, J. Valuation: Measuring and Managing the Value of Companies. 2. ed. New York: John Wiley \& Sons Inc., 1995.

CORREA, E. C. Construção de um Modelo Multicritério de Apoio ao Processo Decisório. Dissertação de Mestrado em Engenharia de Produção, EPS/UFSC, 1996.

COSTA, J. A. F. Classificação automática e análise de dados por redes neurais autoorganizáveis. Tese de Doutorado. Unicamp, Campinas/SP, 1999.

CUMMINS, J. D.; TENNYSON, S.; WEISS, M. A. Consolidation and efficiency in the US life insurance industry. Journal of Banking \& Finance, v.23, p. 325-357, 1999.

CURKOVIC, S. Environmentally Responsible Manufacturing: The development and validation of a measurement model. European Journal of Operational Research, v. 146, p. 130-155, 2003.

DE AZEVEDO, F. M.; BRASIL, L. M. e DE OLIVEIRA, R. C. Redes Neurais com Aplicações em Controle e em Sistemas Especialistas. Florianópolis: Visual Books, 2000.

DEBRUN, M.; GONZALES, M. E. Q.; PESSOA JR, O. Auto-Organização: Estudos Interdisciplinares. Unicamp. São Paulo, 1996.

DESMOND, W. P. L. The Investment Portfolio of the Life Insurance Industry in China: Peculiar Constraints and the Specialist Problem. Risk Management \& Insurance Review, v. 9, Issue 1: 75-88. doi: 10.1111/j.1540-6296.2006.00086.x, 2006.

DIAS, L. M. C.; ALMEIDA, L. M. A. T.; CLÍMACO, J. Apoio Multicritério à Decisão. Faculdade de Economia - Universidade de Coimbra. Coimbra, 1996. 
DIMITRAS, A.I.; ZANAKIS, S. H.; ZOPOUNIDIS, C. A survey of business failure with an emphasis on prediction methods and industrial applications. European Journal of Operational Research. v. 90, p. 487-513, 1996.

DOIGNON, J. P. Threshold representations of multiple semiorders. SIAM Journal of Algebraic Discrete Methods. v. 8, p. 77-84, 1984.

DUCKSTEIN, L.; PARENT, E. Engeneering in natural resources management: with special references to hydrosystems under changes of physical or climatic environment. Kluwer Academic. 1994.

DYSON, R.G.; ALLEN, R.; CAMANHO A. S.; PODINOVSKI, V. V. Pitfalls and protocols in DEA. European Journal of Operational Research, v. 132, p. 245-259, 2001.

EL KADI, H. Modeling the mechanical behavior of fiber-reinforced polymeric composite materials using artificial neural networks-A review. Composite Structures, v. 73, p. 1-23, 2006.

ENGLE, R. GARCH 101: The Use of ARCH/GARCH Models in Applied Econometrics. The Journal of Economic Perspectives. v. 15, n. 4, p. 157-168, 2001.

ENKE, D.; THAWORNWONG, S. The use of data mining and neural networks for forecasting stock market returns. Expert Systems with Applications, v. 29, Issue 4, p. 927-940, 2005.

ENTANI, T.; MAEDA, Y. \& TANAKA, H. Dual Models of Interval DEA and its extensions to interval data. European Journal of Operational Research, v.136, p.32-45, 2002.

ESHO, N.; KIRIEVSKY, A.; WARD, D.; ZURBRUEGG, R. Law and the Determinants of Property-Casualty Insurance. Journal of Risk and Insurance, 71(2), p. 265-283, 2004.

ESSLIN, 1. Apoio à Decisão - Metodologia para estruturação de problemas e avaliação multicritério de alternativas. Florianópolis: Insular, 2001.

FALCÃO, D. M. Redes neurais. Disponível em http://www.nacad.ufrj.br/ falcao

FÄRE, R.; GROSSKOPF, S.; NORRIS M.; ZHANG Z. Productivity growth, technical progress and efficiency change in industrialized countries. American Economic Review, v. 84, p.66-83, 1994.

FARLEY, B. G.; CLARK, W. A. simulation of self-organizing systems by digital computer. Institute of Radio Engeneers Transactions of Professional Group of Information Theory, PGIT4, p. 76-84, 1954.

FARRELL, M.J. The Measurement of Productive Efficiency. Journal of the Royal Statistical Society. Series A (General), v. 120, n. 3, p. 253-290, 1957.

FAUSETT, L.Fundamentals of neural networks: architectures, algorithms, and applications. Englewood Dliffs: Prentice Hall, 1994.

GAMITO, E. J.; CRAWFORD, E. D. (2004). Artificial Neural Networks for Predictive Modeling in Prostate Cancer. Current Oncology Reports, 6:216-221, 2004. 
GAMITO, E. J.; CRAWFORD, E. D.; ERREJON, A. Artificial Neural Networks for Predictive Modeling in Prostate Cancer. In: Jack H. Mydlo and Ciril J. Godec, Editor(s), Prostate Cancer, Oxford: Academic Press, 2003. p. 167-172 geometry. The MIT Press, Massachussets, 1969.

GIL, A. C. Como elaborar projetos de pesquisa. 3a. ed. São Paulo: Altas, 1991.

GILLEN, D.; LALL, A. Developing measures of airport productivity and performance: an application of data envelopment analysis. Transportation Research-E, v.33, p. 261-273, 1997.

GLENN, B. J. Postmodernism: The Basis of Insurance. Risk Management and Insurance Review. v. 6, n. 2, p. 131-143, 2003.

GODET, M.; ROUBELAT, F. Creating the future: the use and misuse of scenarios. Long Range Planning, v. 29, n. 2, p. 164-171, 1996.

GOICOECHEA, A.; HANSEN, D. R.; DUSCKSTEIN, L. Multiobjective Decision Analysis with Engineering and Business Applications. New York, John Wiley \& Sons, 1982.

GOLANY, B.; ROLL, Y. An application procedure for DEA.OMEGA Internacional Journal of Managment Science, Great Britain, v. 17, n. 3, p. 237-250, 1989.

GOMES, E.; MELLO, J.; LUIZ NETO, B e MEZA, L.A. Gestão de auto-estradas: Análise de eficiência das auto-estradas federais brasileiras com portagens. Revista Portuguesa e Brasileira de Gestão, Lisboa - Rio de Janeiro, v. 3, n. 2, p. 68-75, 2004.

GROSSBERG, S. A neural model of attention, reinforcement, and discrimination learning. International Review of Neurobiology, 18, 263-327, 1975.

GROSSBERG, S. Adaptive pattern classification and universal recoding, I: Parallel development and coding of neural feature detectors \& II: Feedback, expectation, olfaction, and illusions. Biological Cybernetics, 23:121-134 \& 187-202, 1976.

GUJARATI, D. Econometria Básica. São Paulo: Makron Books, 2000.

HAOFEI, Z.; GUOPING, X.; FANGTING, Y.; HAN, Y. (2006). A neural network model based on the multi-stage optimization approach for short-term food price forecasting in China, Expert Systems with Applications. In: Press, Corrected Proof, Available online, 2006.

HARTMAN, D. H.; GOLTZ, M. N. Application of the Analytic Hierarchy Process to select characterization and risk-based decision making and management methods for hazardous waste sites. Environ Eng Policy, v. 3, p. 1-7, 2002.

HASSAN, M. R.; NATH, B. (2005). Stock market forecasting using hidden markov model: a new approach. In: Proceedings of 5th international conference on intelligent system design and application, Poland, pp. 192-196, 2005.

HASSAN, R.; NATH, B.; KIRLEY, M. A fusion model of HMM, ANN and GA for stock market forecasting, Expert Systems with Applications. In: Press, Corrected Proof, Available online, 3 May 2006. 
HAYKIN, S. Redes neurais: princípios e práticas. Trad. Paulo Martins Engel, $2^{\mathrm{a}}$ ed., Porto Alegre: Bookman, 2001.

HEBB, D. O. THe Organization of Behavior: A Neurophysiological Theory. New York. Wiley, 1949.

HOPFIELD, J. J.; TANKS, D. W. Computing with neural circuits: a model. Science Magazine, v. 233, p. 625-633, 1986.

HOPFIELD, J. J.Neural Networks and physical systems with emergent collective computational abilities. Proceedings of the National Academy of Science of the United States of America, 79, p. 2554-558, 1982.

HORN, R. V. Statistical Indicators: For the economics \& Social Sciences. Cambridge University Press, 1993.

HOYT, R. E.; MCCULlOUGH, K., A. Catastrophe insurance options: Are they zero-beta assets? Journal of Insurance Issues, vol. 22, n² 2, p. 147, 1999.

HUARNG, K.; YU, T. H. K. The application of neural networks to forecast fuzzy time series. Physica A: Statistical Mechanics and its Applications, v. 363, Issue 2, p. 481-491, 2006.

HUBEL, D.; Wiesel, T. Receptive fields, binocular interaction and functional architecture in the cat's visual cortex. Journal of Physiology, 160:106-154, 1962.

IAÑEZ, M. M. Uma contribuição ao processo decisório de terceirização de atividades logísticas. Dissertação de Mestrado. Escola Politécnica, Universidade de São Paulo, São Paulo, 2002.

KAO, C.; HWANG, S. H. (2006). Efficiency decomposition in two-stage data envelopment analysis: An application to non-life insurance companies in Taiwan. European Journal of Operational Research, doi:10.1016/j.ejor.2006.11.041, 2007.

KIM, H.; KWON, W. J. (2006). A multi-line insurance fraud recognition system: a government-led approach in Korea. Risk Management and Insurance Review, v. 9, No. 2, 131-147, 2006.

KING, R. G.; LEVINE, R. Finance and Growth: Schumpeter Might Be Right. Quarterly Journal of Economics, 108, p. 717-737, 1993.

KING, R. G.; LEVINE, R. Finance, Entrepreneurship, and Growth: Theory and Evidence. Journal of Monetary Economics, 32, p. 513-542, 1993.

KLOPF, A. H. A neuronal model of classical conditioning, v.16, 2, 85-125, 1988.

KOHONEN, T. An Introduction to Neural Computing. Neural Networks, v. 1, p. 3-16 Finland: Helsinki University of Technology, 1988.

KOHONEN, T. Exploration of very large databases by self-organizing maps. In: Proceedings of ICNN'97, International Conference on Neural Networks, v. 1, pp PL1- 
KOHONEN, T. Physiological interpretation of the self-organized map algorithm. NeuralNetworks, 6(7):895-905, 1993.

KOHONEN, T. Self-organized formation of topologically correct feature maps. Biological Cybernetics, v. 43, pp. 59-69, 1982.

KOHONEN, T. The self-organizing map. In: Proceedings of the Institute of Electrical and Electronics Engineers, v. 78, pp 1464-1480, 1990.

KOSKO, B. Neural Networks and Fuzzy Systems: a dynamical approach to ma-chine intelligence. Prentice Hall, N.J., EUA, 1992.

LEE, H.; KWAK, W.; HAN, I. Developing a business performance evaluation system: an analytic hierarchical model. The Engineering Economist. 30 (4), p. 343-357, 1995.

LEUNG, K. S.; JIN, H. D.; XU, Z. B. An expanding self-organizing neural network for the traveling salesman problem. Neurocomputing, 62 (2004) 267 -292, 2004.

LEVINE, R. Law, Finance, and Economic Growth. Journal of Financial Intermediation, 8(12), p. 8-35, 1999.

LEVINE, R.; LOAYZA, N.; BECK, T. Financial Intermediation and Growth: Causality and Causes. Journal of Monetary Economics. 46(1), p. 31-77, 2000.

LEVINE, R.; ZERVOS, S. Stock Markets, Banks, and Economic Growth. American Economic Review, 88(2), p. 537-558, 1998.

LI, D.; SIM, A. B.; MOSHIRIAN, F. The Determinants of Intra-Industry Trade in Insurance Services. Journal of Risk and Insurance, 70(2): 269-287, 2003.

Life Insurance Corporation of India using data envelopment analysis. Socio-Economic Planning Sciences, v. 39, p. 261-285, 2005.

LINS, M. P. E.; MEZA, L. A. Análise Envoltória de Dados e Perspectivas de Integração no ambiente de Apoio à Decisão. Rio de Janeiro: COPPE / UFRJ, 2000.

LINSKER, R. From Basic Network Principles to Neural Architecture Proceedings of the National Academy of Sciences. USA, v. 83, pp. 7508-7512, 8390-8394, 8779-8783, 1986.

LO, Z. P.; FUJITA, M.; BAVARIAN, M. Analysis of convergence properties of topology preserving neural networks. IEEE Transactions on neural Networks, v. 4, p.207-220, 1993.

LO, Z. P.; FUJITA, M.; BAVARIAN, M. Analysis of neighborhood interaction in Kohonen neural networks. 6th International Parallel Processing Symposium Proceedings. p. 247-249, 1991.

LOVELL, K.C.A; SCMIDT, P.A A comparison of alternative approaches to the measurement of productive efficiency. In: Applications of madern production theory. Boston: Kluwer Academic Publishers, p.3-32, 1988. 
MACRAE, D. Policy Indicators: links between social science and public debate. Chapel Hill: University of North Carolina Press, 1985.

MALCZEWSKI, J. GIS and Multicriteria Analysis. John Wiley \& Sons, 1999.

MALIK, F.; NASEREDDIN, M. Forecasting output using oil prices: A cascaded artificial neural network approach. Journal of Economics and Business, v. 58, Issue 2, p. 168-180, 2006.

MAYERSON, A. Introduction to insurance. New York: MACMILLAN, 1962.

McCULLOCH, W. S.; PITTS, W. A. A logical calculus of the ideas immanent in nervous activity. Bulletin of Mathematics Biophysics 5, 115-133, 1943.

MEHROTRA, K.; MOHAN, C.; RANKA, S. Elements of Artificial Neural Networks. MIT Press, 2000.

MILLER, R., A. The weighted average cost of capital is not quite right. The Quarterly Review of Economics and Finance. In Press, Corrected Proof, 2006.

MINSKY, M. L.; PAPERT, S. A. Perceptrons: an introduction to computacional

MONTIBELLER, G.; BELTON, V.; ACKERMANN, F.; ENSSLIN, L. Reasoning maps for decision aid: an integrated approach for problem-structuring and multi-criteria evaluation. Journal of the Operational Research Society, p. 1-15, 2007.

MORGAN, D.; SCOFIELD, C. Neural Networks and Speech Processing. Boston: Kluwer, 1991.

NORMAN, M.; STOKER, B. Data Envelopment Analysis: the assessment of performance. Chichester: John Wiley, 1991.

OLIVEIRA, S. L. Sociologia das organizações. São Paulo: Pioneira, 1999.

Organization For Economic Co-Operation And Development. Insurance Statistics Yearbook, disponível em: http://miranda.sourceoecd.org. Consultado em: 29 de junho de 2007.

ORMONEIT, D. A regularization approach to continuous learning with an application to financial derivatives pricing. Neural Networks, v.12, Issue 10, p. 1405-1412, 1999.

OSÓRIO, F.; BITTENCOURT, J. R. Sistemas inteligentes baseados em RNAs aplicados ao processamento de imagens. In: Workshop de Inteligência Artificial. Santa Cruz do Sul: UNISC, 2000.

OSTASZEWSKI, K. Is life insurance a human capital derivatives business? Journal of Insurance Issues. v. 26, n. 1, 2003.

OUTREVILLE, J. F. The Economic Significance of Insurance Markets in Developing Countries. Journal of Risk and Insurance, 18(3), p. 487-498, 1990. 
OUTREVILLE, J. F. The Retention Capacity of Insurance Markets in Developing Countries. In: G. Dionne,ed., Handbook of Insurance. Boston: Kluwer, 2000. pp. 749-766.

PAO, H. T. Forecasting electricity market pricing using artificial neural networks, Energy Conversion and Management, In Press, Corrected Proof, Available online, 2006.

PEREIRA, M.F. Menssuramento da eficiência multidimencional utilizando a análise de envelopamento de dados; revisão da teoria e aplicações. Dissertação de mestrado da Universidade Federal de Santa Catarina, Florianópolis, 1995.

PL6. IEEE Service Center:Piscataway, Houston, 1997.

PLOCEK, J. W. Economic Indicators: How America Reads Its Financial Health. New York, NY: New York Institute of Finance, 1991.

QURESHI, M. E.; HARRISON, S. R.; WEGENER, M. K. Validation of multicriteria analysis models. Agricultural Systems 62, p. 105-116, 1999.

RITTER, H.; MARTINETZ, T.; SCHULTEN, K. Neural Computation and Self-Organizing Maps: An Introduction. Addison-Wesley, 1992.

ROSENBLATT, F. The perceptron: a probabilistic model for information storage and retrieval in the brain. Psychological Review, v. 65, p. 386-408, 1958.

ROUBENS, M.; RUSINOWSKA, A.; STEWART, H. Using MACBETH to determine utilities of governments to parties in coalition formation. European Journal of Operational Research, v. 172, p. 588-603, 2006.

ROY, B. Classement et choix en presence de points de vue multiple: La methode ELECTRE. R.I.R.O, v. 8, p.57-75, 1978.

ROY, B. Multicriteria Methodology for Decision Aiding. Dordrecht / Boston / London: Kluwer Academic Publishers, 1996.

ROY, B.; BOUYSSOU, D. Aide Multicritère à la Décision: Méthods et Cas. Economica: Paris, 1993.

RUDIO, F. V. Introdução ao Prometo de Pesquisa Científica. Petrópolis: Editora Vozes, 1982.

RUMELHART D. E.; ZIPSER D. Feature discovery by competitive learning. Cognitive Science, v. 9, pp. 75-112, 1985.

RUMELHART, D.E.; HINTON, G.E.; WILLIAMS, R. J. Learning representations by backpropagation errors. Nature, v. 323, p. 533-536, 1986.

SAHA, A.; RAVISANKAR, T. S. Rating of Indian commercial banks: a DEA approach. European Journal of Operational Research, v. 124, p. 187-203, 2000.

SAMPIERI, R. H.; COLLADO, C. F.; LUCIO, P. B. Metodologia de la investigación. México: McGraw-Hill, 1991. 
SCHAFFNIT, C.; ROSEN, D.; PARADI, J. C. Best practice analysis of bank branches: an application of DEA in a large Canadian bank. European Journal of Operational Research, v. 98, p. 269-289, 1997.

SCHÖNEBURG, E. Stock price prediction using neural networks: A project report. Neurocomputing, v. 2, Issue 1, p. 17-27, 1990.

SENGUPTA, J. K. Efficiency Analysis by Production Frontiers: The Nonparametric Approach. Kluwe Academics Publishers, 1989. 246 p.

SIEMS, T. F.; BARR, R. S. Benchmarking the productive efficiency of U.S. banks. Financial Industry Studies, p.11-24, 1998.

SIGMA. World Insurance in 2000: Another Boom Year for Life Insurance; Return to Normal Growth for Non-Life Insurance. Zurich: Swiss Reinsurance Company Economic Research \& Consulting, 2001.

SILVA, I. N.; AMARAL, W. C.; ARRUDA, L. V. R. Uma abordagem usando redes neurais artificiais para resolução de problemas de otimização restrita. Pesquisa Operaciona,. v. 24, n. $2,2004$.

SIMPSON, P. K. Artificial neural system-foundation, paradigm, application and implementation. New York: Pergamon Press, 1990.

SISKOS, Y.; ZOPOUNIDIS, C.; POULIEZOS, A. Na? integrated DSS for financing firms by an industrial development bank in Greece. Decision Support Systems v.12, p. 151-168, 1994.

SMITH, K. A.; GUPTA, J. N. D. Neural networks in business: techniques and applications for the operations researcher. Computers \& Operations Research, pp. 1023-1044, 2000.

SOARES DE MELLO, J. C. C. B.; GOMES, E. G.; LINS, M. P. E. Análise Multicritério da presença da Universidade Federal Fluminense com o uso do Método Macbeth. Revista Produção, v. 11 (2), p. 53-67, 2002.

SOARES DE MELlO, J. C. C. B.; LINS, M. P. E.; SOARES DE MELlO, M. H. C.; GOMES, E. G. Evaluating the performance of Calculus classes using operational research tools. European Journal of Engineering Education, v. 27 (2), p. 209-218, 2002.

SOARES DE MELLO, J.C.C.B; MEZA, L.A.; GOMES, E.G.; BIONI NETO, L. Curso de Análise de Envoltória de Dados, In: XXXVII Simpósio Brasileiro De Pesquisa Operacional (SBPO). Gramado, RS, 2005.

SOUCEK, B. Neural and Intelligent Systems Integration. New York: John Wiley and Sons, 1991.

SOUZA, D.P.H. Avaliação de métodos paramétricos e não paramétricos na análise da eficiência da produção de leite. Dissertação de Mestrado da Escola Superior de Agricultura "Luiz de Queiroz", Universidade de São Paulo, São Paulo, 2003. 
SPRONK, J.; HALLERBACH, W. Financial Modeling: where to go? With na illustration of portfólio management. European Journal of Operational Research, v. 99, p. 113-125, 1997.

STANDERSKI, W.; KRAVEC, A. Seguros Privados e Previdência Complementar. Editora Pioneira, 1979.

STEINBUCH, K. Die Lernmatrix. Kybernetik, 1, 136-45, 1961.

TATIKONDA, M.V.; WEMMERLOV, U. Adoption and implementation of classification and coding systems: insights form seven case studies. Internal Journal of Production Researcxh, v. 30, n. 9, p. 2097-2110, 1992.

TERÄSVIRTA, T.; DIJK, D. V; MEDEIROS, M. C. Linear models, smooth transition autoregressions, and neural networks for forecasting macroeconomic time series: A reexamination. International Journal of Forecasting, v. 21, Issue 4, Nonlinearities, Business Cycles and Forecasting, p. 755-774, 2005.

THANASSAOULIS, E.; DUSTAN, P. Guiding schools to improved performance using Data Envelopment Analysis: an illustration with data from a local education authority. Journal of Operational Research Society. v. 45, n. 11, p. 1247-1262, 1996.

THANASSOULIS, E. Introduction to the theory and application of data envelopment analysis: a foundation text with integrated software. Kluwer Academic Publishers, 2001.

TONE, K.; SAHOO, B. K. Evaluating cost efficiency and returns to scale in the

UNCTAD. Statistical Survey on Insurance and Reinsurance Operations in Developing Countries. New York: United Nations, 1994.

UNCTAD. The Promotion of Life Insurance in Developing Countries, TD.B.C3/177. Geneva: United Nations, 1982.

VARIAN, H.R. Microeconomic Analysis, 3rd Edition. New York and London: W.W. Norton, 1992.

VINCKLE, P. Multicriteria decision-aind. John Wiley \& Sons, 1992.

WARD, D.; ZURBRUEGG, R. Does Insurance Promote Economic Growth?: Evidence From OECD Countries. Journal of Risk and Insurance, 67(4), p. 489-507, 2002.

WARD, P. T.; STORBECK, J. E.; MAGNUM, S. L.; BYRNES, P. E. An analysis of staffing efficiency in U.S. manufacturing: 1983 and 1989. Annals of Operations Research, v. 73, p.6789, 1997.

WATSON, S. R.; BUEDE, D. M. (1987). Decision Synthesis. Cambridge University Press: Cambridge, 1987.

WIDROW, B.; HOFF, M. E. Adaptive Switching Circuits. 1960 WESCON Convention, Record Part IV, pp. 96-104, 1960. 
WILLSHAW, D. J., MALSBURG, C. V. D. How Patterned neural connections can be set up by self-organization. Proceedings of the Royal Society of London Series B, v. 194, pp. 431445, 1976.

WONG, B. K.; LAI, V. S.; LAM, J. A bibliography of neural network business applications research: 1994-1998. Computers \& Operations Research, v. 27, Issues 11-12, p. 1045-1076, 2000 .

WONG, B. K.; MONACO, J. A. Expert system applications in business: A review and analysis of the literature (1977-1993). Information \& Management, v. 29, Issue 3, p. 141-152, 1995.

WONG, B. K.; SELVI, Y. Neural network applications in finance: A review and analysis of literature (1990-1996). Information \& Management, v. 34, Issue 3, 1, p. 129-139, 1998.

WONG, B. K; BODNOVICH, T. A.; SELVI, Y. Neural network applications in business: A review and analysis of the literature (1988-1995). Decision Support Systems, v. 19, Issue 4, p. 301-320, 1997.

XUEFENG, L.; LU, L.; LIHUA, W.; ZHAO, Z. Predicting the final prices of online auction items. Expert Systems with Applications, v. 31, Issue 3, p. 542-550, October 2006.

YAMANDA, Y.; MATUI, T. \& SUGIYAMA, M. New analysis of efficiency base on DEA. Journal of the Operations Research Society of Japan, v. 37, n.2, p.158-167, 1994.

YANG, Z. A two-stage DEA model to evaluate the overall performance of Canadian life and health insurance companies. Journal Mathematical and Computer Modelling, v. 43 (2006) 910-919, 2005.

YAO, S.; HAN, Z.; FENG, H. On technical efficiency of China's insurance industry after WTO accession. China Economic Review, v. 18, p. 66-86, 2007.

YUN, Y. B.; NAKAYAMA, H.; TANINO, T. A generalized model for data envelopment analysis. European Journal of Operational Research, pp. 87-105, 2004.

ZEIK, S. A vision of the brain. Blackwell Scientific Pub. Oxford, Londres, 1993.

ZHANG, G. B.; PATUWO, e.; HU, M.Y. Forecasting with artificial neural networks: The state of the art. International Journal of Forecasting, v. 14, Issue 1, 1 March 1998, p. 35-62, 1998.

ZOPOUNIDIS, C. Multicriteria decision aid in financial management. European Journal of Operational Research, v. 119, P. 404-415, 1999.

ZOPOUNIDIS, C.; DOUMPOS, M. (2002). Multicriteria Decision Aid in Financial Decision Making: Methodologies and Literature Review. Journal of Multicriteria Decision Analysis, v. 11, 4-5; p. 167.

ZURADA, J. M. Introduction to Artificial Neural Systems. Boston, Mass: West Publishing Company, 1992. 